\title{
Light Water Reactor Sustainability Program
}

EXPECTED CONDITION OF CONCRETE EXPOSED TO RADIATION AT AGE 80 YEARS OF REACTOR OPERATION

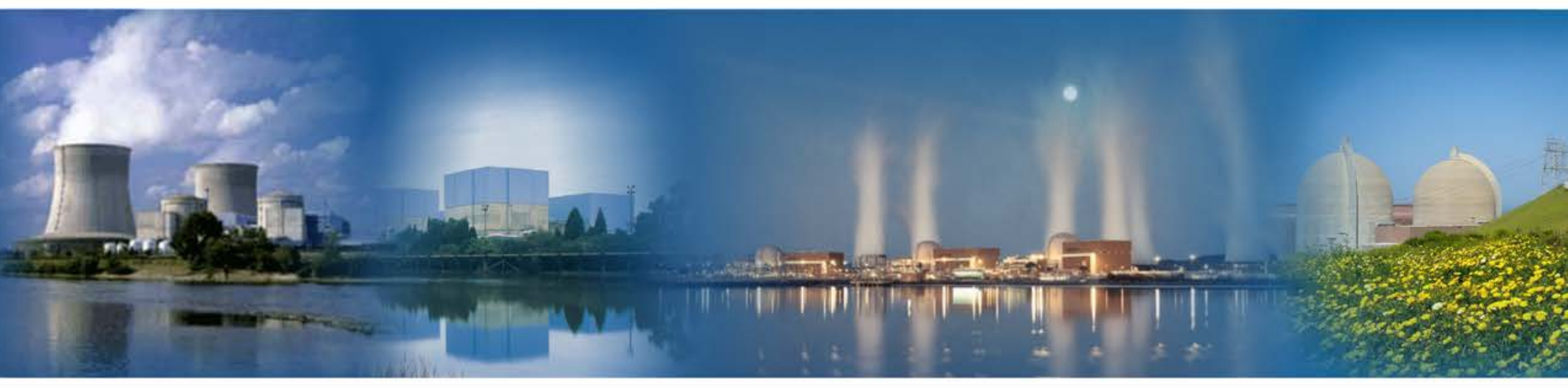

January 2018

U.S. Department of Energy

Office of Nuclear Energy 


\section{DISCLAIMER}

This information was prepared as an account of work sponsored by an agency of the U.S. Government. Neither the U.S. Government nor any agency thereof, nor any of their employees, makes any warranty, expressed or implied, or assumes any legal liability or responsibility for the accuracy, completeness, or usefulness, of any information, apparatus, product, or process disclosed, or represents that its use would not infringe privately owned rights. References herein to any specific commercial product, process, or service by trade name, trade mark, manufacturer, or otherwise, does not necessarily constitute or imply its endorsement, recommendation, or favoring by the U.S. Government or any agency thereof. The views and opinions of authors expressed herein do not necessarily state or reflect those of the U.S. Government or any agency thereof. 
ORNL/TM-2018/769

Revision 0

\title{
EXPECTED CONDITION OF CONCRETE EXPOSED TO RADIATION AT AGE 80 YEARS OF REACTOR OPERATION
}

\author{
From LPI Report No. \\ A13276-R-001 \\ Rev. No: 0 \\ December 2013
}

\author{
Prepared by \\ Thomas Esselman and Paul Bruck \\ LPI, Inc. \\ Forward by \\ Thomas M. Rosseel \\ Oak Ridge National Laboratory
}

January 2018

Prepared for the

U.S. Department of Energy

Office of Nuclear Energy 


\title{
Light Water Reactor Sustainability Program
}

\section{Expected Condition of Concrete Exposed to Radiation at Age 80 Years of Reactor Operation}

\author{
ORNL/TM-2018/769 \\ Revision 0 \\ January 2018
}

\section{Approved by:}

Thomas M. Rosseel

Deputy Pathway Lead, Materials Aging and Degradation

Date

Title [optional]

Date

Title [optional]

Date

Name

Title [optional]

Date 


\section{FOREWORD}

This report is intended to provide access to information generated by LPI, Inc. on behalf of the US Department of Energy (DOE), Office of Nuclear Energy, Light Water Reactor Sustainability (LWRS) Program and the Electric Power Research Institute (EPRI) in 2013. Specifically, estimates of the fast neutron fluence at 80 years of operation on the outer surface of the concrete biological shield (CBS) of US Nuclear Power Plants (NPPs) operating in 2013 and an estimate of the effects of gamma radiation on the temperature on the biological shield were determined.

The degradation of the structural capability of the biological shield wall can be affected by two primary mechanisms: elevated thermal temperatures during reactor operation and nuclear radiation. Elevated temperatures inside and outside the CBS wall can degrade concrete structures by accelerating the depletion, or vaporization, of the moisture content in the concrete. High radiation dose due to neutron and gamma bombardment can damage concrete structures by changing the material characteristics when collisions with radiation particles occur and by increasing the temperature of the concrete.

Monitoring thermal temperatures in the plant can be performed using thermocouples or other temperature measuring devices. Temperatures of the air moving past the inside surface of the biological shield wall can be determined. With the use of thermodynamic analysis, temperature profiles throughout the concrete structures can be calculated.

Monitoring radiation energies and the resulting damage to concrete materials throughout the CBS wall, however, is not as well defined as determining temperature profiles. Radiation levels that are routinely tracked for the reactor vessel can be used to define the radiation at the inside of the biological shield wall. From this information the attenuation of the radiation can be calculated and the impact on the concrete properties assessed based on existing radiation damage models. The effects of gamma radiation on the temperature of the CBS can also be calculated.

The purpose and scope of this investigation, therefore, is to provide information on the expected levels of radiation during operation of NPPs to 80 years for the CBS wall surrounding the reactor. This work does not provide a plant-by-plant qualification, but uses the plants in the US fleet to calculate an expected radiation level at 80 years. Specific data is presented to allow a plant specific evaluation to be performed. This report also provides recommendations for testing and consideration of other issues that may be useful to supplement existing information.

A similar version of the LPI report was published in an EPRI report (Expected Condition of Reactor Cavity Concrete After 80 Years of Radiation Exposure, EPRI, Palo Alto, CA: 2014, 3002002676), which is not publicly available.

T. M. Rosseel, Oak Ridge National Laboratory 
Lucius Pitkin, Inc. Consulting Engineers

Advanced Analysis Failure \& Materials Evaluation

Fitness-For-Service Nondestructive Engineering

\title{
EXPECTED CONDITION OF CONCRETE EXPOSED TO RADIATION AT AGE 80 YEARS OF REACTOR OPERATION
}

Report No.

A13276-R-001

Rev. No: 0

December 2013

Prepared For

UT-BATTELLE ENERGY ALLIANCE, LLC OAK RIDGE NATIONAL LABORATORY

\section{ELECTRIC POWER RESEARCH INSTITUTE}

\author{
Prepared By \\ LPI, Inc.




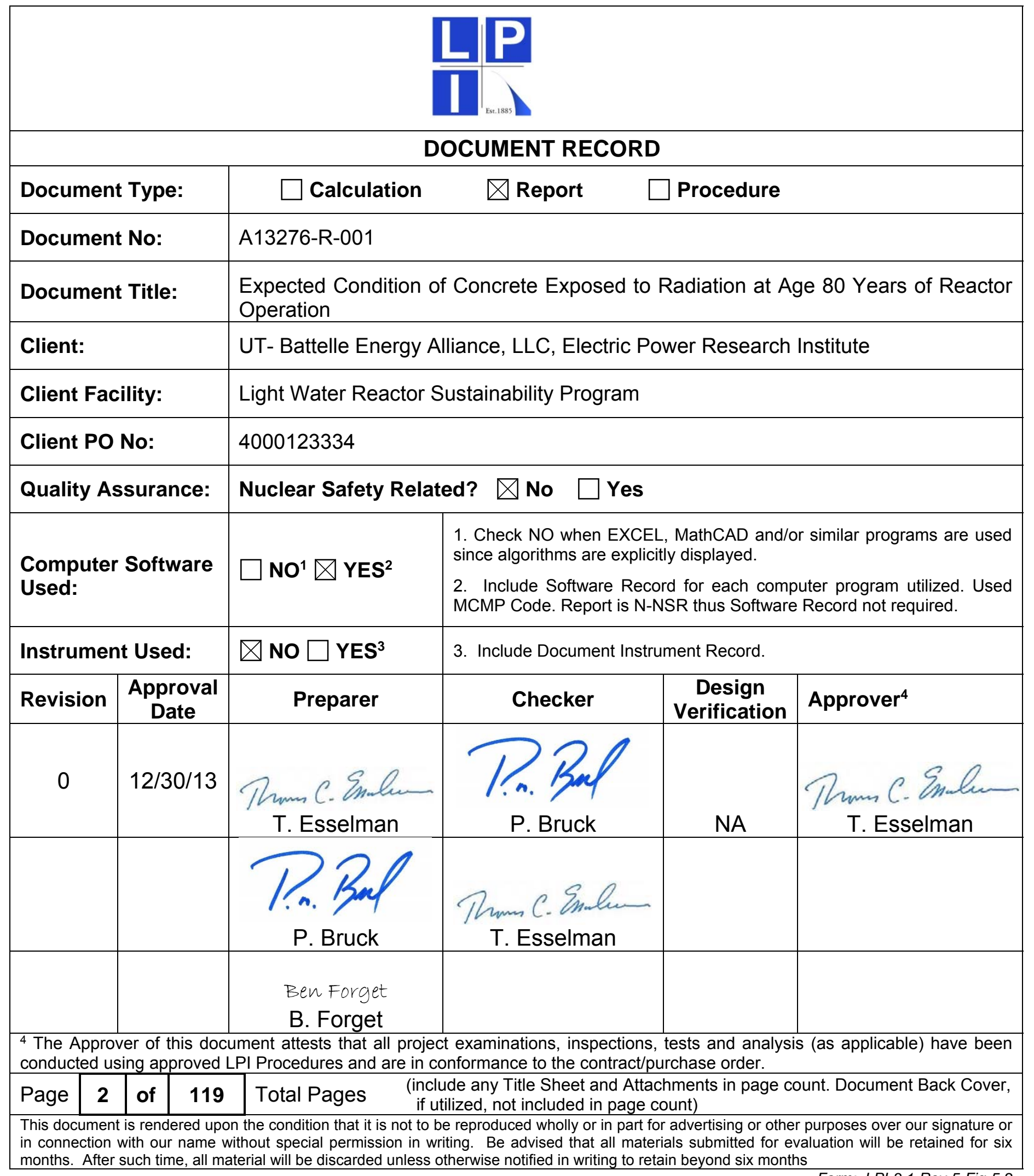

Form: LPI-3.1-Rev-5-Fig-5-2 


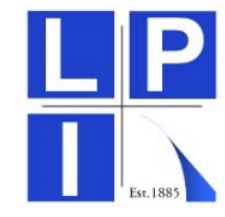

\section{RECORD OF REVISION}

\begin{tabular}{|c|c|l|l|}
\hline Revision No. & Date & Description of Change & Reason \\
\hline \multirow{3}{*}{0} & $\begin{array}{c}\text { See } \\
\text { Document } \\
\text { Record } \\
\text { Page }\end{array}$ & Original Issue & \\
\hline & & & \\
\hline & & & \\
\hline
\end{tabular}

Form: LPI-3.1-Rev-5-Fig-5-7 


\section{TABLE OF CONTENTS}

Page No.

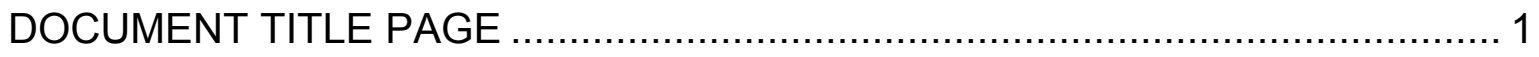

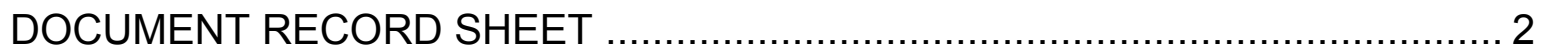

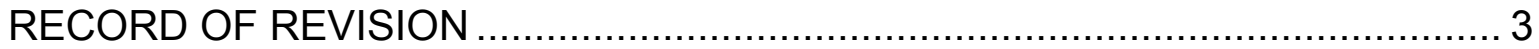

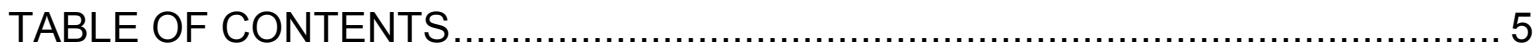

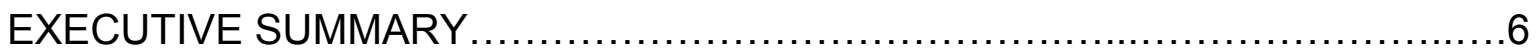

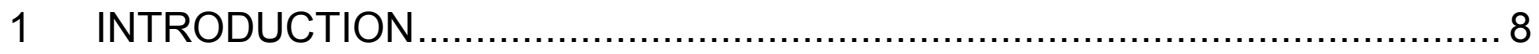

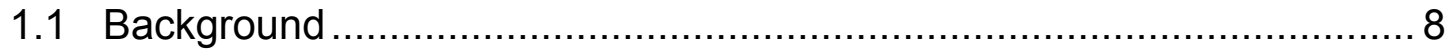

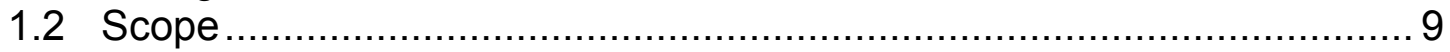

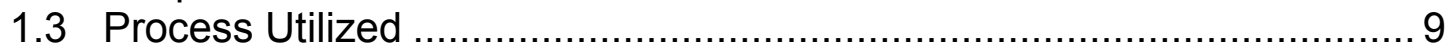

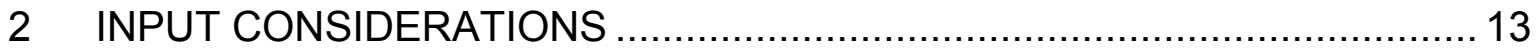

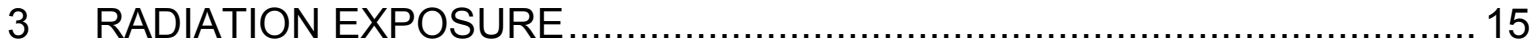

3.1 Radiation in Concrete.............................................................. 15

3.2 Neutron Fluence in RPV ......................................................... 16

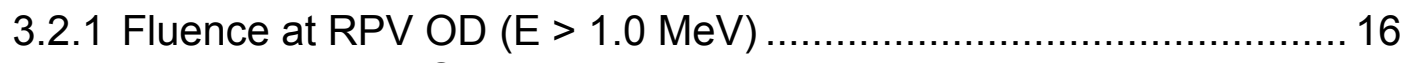

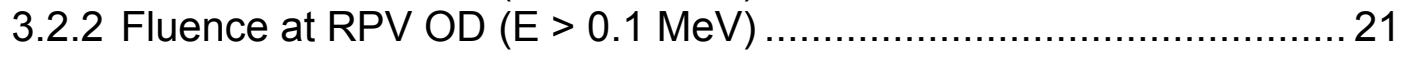

3.2.3 Neutron Flux Variation along Active Fuel..................................... 25

3.3 Fluence at ID of Concrete ....................................................... 25

3.4 Enveloping Fluence in Concrete ………….............................. 26

3.4.1 Neutron Fluence - 2 Loop Plant ............................................... 26

3.4.2 Neutron Fluence - 3 Loop Plant .............................................. 26

3.4.3 Enveloping Neutron Fluence - US Fleet..................................... 27

3.5 Gamma Radiation ........................................................................ 27

4 RADIATION ATTENUATION AND HEATING IN CONCRETE .................... 30

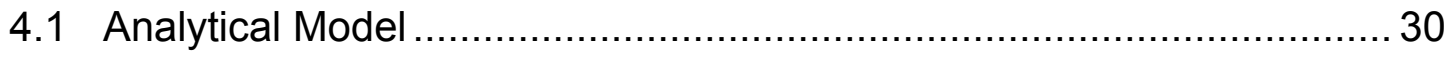

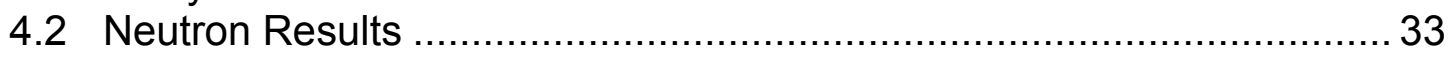

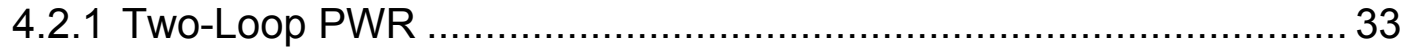

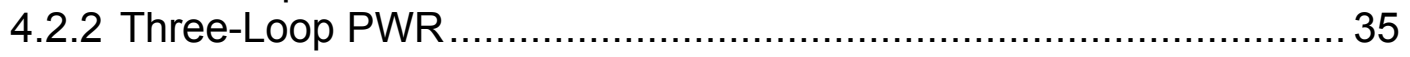

4.2.3 Rate of Neutron Attenuation ................................................... 38

4.2.4 Two and Three-Loop PWR Results with Rebar ............................ 40

4.2.5 Gamma Attenuation - Photon Dose ......................................... 42

4.3 Gamma Heating Evaluation ..................................................... 47

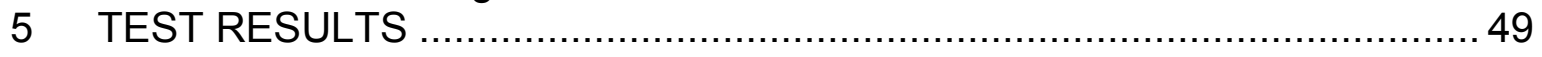

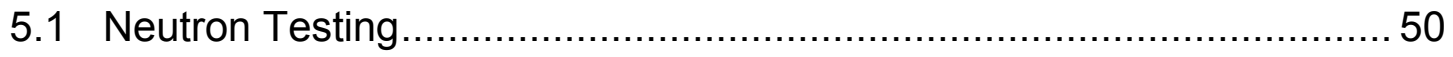

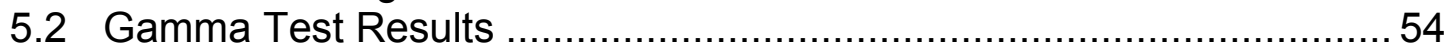

6 CONCRETE MATERIAL CHARACTERIZATION ..................................58

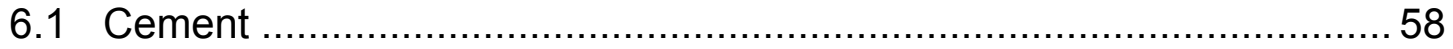

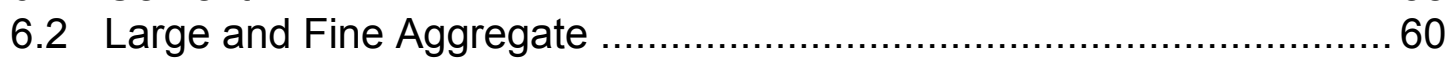

6.2.1 Heavy Aggregates Used for Radiation Shielding ...........................6 61

Report No. A13276-R-001

Page 4 of 92

Revision 0 


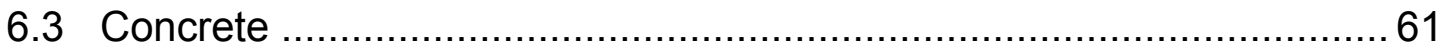

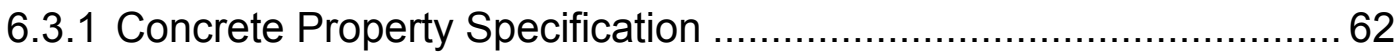

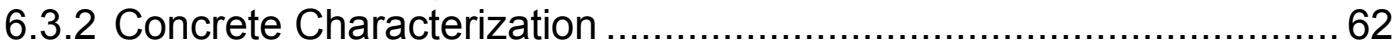

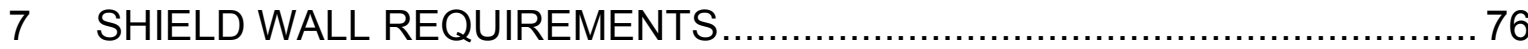

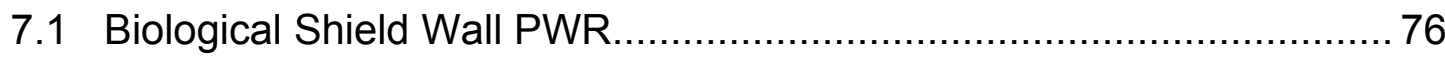

7.1.1 Westinghouse NSSS Designs .................................................. 76

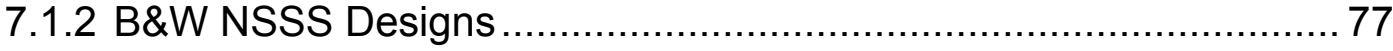

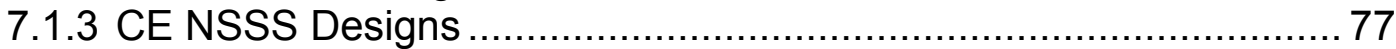

7.1.4 Plant Survey Dimensions for RPV Shoe Designs .......................... 78

7.2 Biological Shield Wall BWR …......................................................... 78

8 EXPECTED CONCRETE CONDITION AT 80 YEARS ….......................... 86

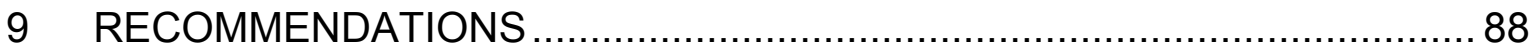

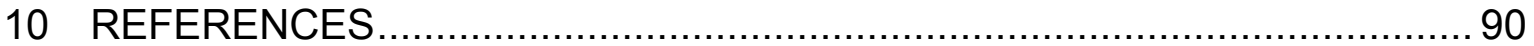

ATTACHMENTS

A - Detailed Assessment of US Fleet Fluence

No. $p p$

B - 2-loop and 3-loop PWR Concrete Attenuation Analysis 


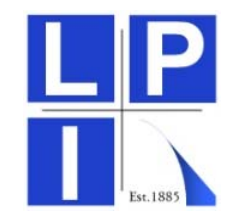

\section{LIST OF FIGURES}

Figure 1-1: Typical Configuration of PWR RPV and Biological Shield Structure .. 11 Figure 1-2: Typical Configuration of BWR RPV and Biological Shield Structure . 12 Figure 3-1: Summary of US PWR Fleet Fluence, RPV 1T at 80 years $(E>1.0 \mathrm{MeV})$ 19

Figure 3-2: Summary of US BWR Fleet Fluence at 80 years $(E>1.0 \mathrm{MeV}) \ldots . .20$ Figure 3-3: Ratio of E>0 $0.1 \mathrm{MeV}$ to $1.0 \mathrm{MeV}$ vs. RPV Thickness ...................... 22 Figure 3-4: Summary of US PWR Fleet Fluence at 80 years $(E>0.1 \mathrm{MeV}) \ldots \ldots .23$ Figure 3-5: Summary of US BWR Fleet Fluence at 80 years $(E>0.1 \mathrm{MeV}) \ldots \ldots . .24$ Figure 3-6: Axial Neutron Flux Variation Relative to Core Fuel Mid-Height .......... 25 Figure 3-7: Axial Gamma Flux Variation Relative to Core Fuel Mid-Height ......... 29 Figure 4-1: Shield Wall Reinforcing at a Sample 4-loop PWR ........................... 32 Figure 4-2: Neutron Flux $\left(\mathrm{n} / \mathrm{cm}^{2} \mathrm{~s}\right.$ - normalized per source neutron) attenuation in Portland concrete (2-loop model)......................................................... 35 Figure 4-3: Neutron Flux (n/cm ${ }^{2} \mathrm{~s}$ - normalized per source neutron) attenuation in Portland concrete (3 loop model)............................................................. 38 Figure 4-6: Mass energy attenuation coefficient (from NIST) .......................... 43 Figure 4-9: Photon Flux in Concrete with and without Rebar- Two Loop Plant ... 46 Figure 4-10: Dose Rate ( $\mathrm{rad} / \mathrm{sec})$ in Concrete with and without Rebar - Two Loop

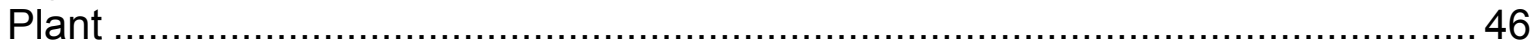

Figure 4-11: Radial Profiles of Temperature Increase in Concrete from Ambient and Radiation Heating [5] ........................................................................... 48 Figure 5-1: Compressive strength of concrete exposed to neutron radiation $\mathrm{f}_{\mathrm{cu}}$ related to strength of untreated concrete $f_{\text {cuo }}$ (Reprinted from [19]) ....................49 Figure 5-2: Compressive and tensile strength of concrete exposed to gamma radiation $f_{\text {cu }}$ related to strength of untreated concrete $f_{\text {cuo }}$ (Reprinted from [19]) ...50 Figure 5-3: Compressive strength data points from Hilsdorf [25] paper that may not be representative of commercial LWRs (Reprinted from [2]) .............................51

Figure 5-4: Fujiwara Data - "Fast Neutrons" > $0.1 \mathrm{MeV}$................................. 52 Figure 5-5: Gamma dose data points from Hilsdorf [19] paper that may not be representative of commercial LWRs (reprinted from [2]) ….............................55 Figure 5-6: Data from Soo and Milian [23] shows reduction in strength at $1 \mathrm{E}+9$ rads (10 MegaGy) for a dose rate of $3.8 \mathrm{E}+5$ rads per hours (3.8 E+3 Gy per hour)....56 Figure 5-7: Data from Sopko, et. al. [24] shows continual reduction in strength

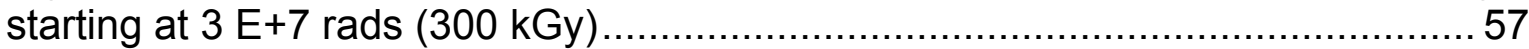
Figure 6-1: Geographic Representation of US Study Plant Locations ..................6 68 Figure 6-2: Comparison of Selected Plant Cement Elements to Portland cement "Reference Composition".... 69

Figure 6-3: US Aggregate Map with Study Plants Located .............................. 70

Figure 6-4: Comparison of Selected Plant Aggregate Elements........................ 71 Figure 6-5: Comparison of Coarse to Fine Aggregates for Selected Study Plants 72

Figure 6-6: Comparison of Concrete for Selected Study Plants 73

Report No. A13276-R-001

Page 6 of 92

Revision 0 
Figure 6-7: Comparison of Concrete for Selected Study Plants ........................ 74

Figure 6-8: Average Element Values for Selected Concrete Types.................... 75

Figure 7-1: W RPV Support Configuration Type I [44] ................................... 79

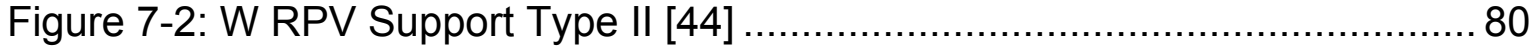

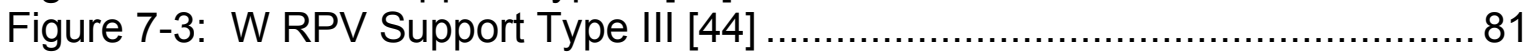

Figure 7-4: W RPV Support Type IV [44] ............................................... 82

Figure 7-5: Dimensional Configuration for Plant Specific Survey ........................ 83

\section{LIST OF TABLES}

Table 3-1: Assessment of Flux Attenuation Equation $(\mathrm{E}>1.0 \mathrm{MeV}) \ldots \ldots \ldots \ldots \ldots \ldots . . . .18$

Table 3-2: Assessment of Increase Ratio for $E>0.1$ to $E>1.0 \mathrm{MeV} \ldots \ldots \ldots \ldots \ldots \ldots . . .21$

Table 3-3: Ratio of Flux at ID of Concrete vs. OD of PWR RPV (E > 0.1 MeV) ... 26

Table 3-4: Gamma Flux and Dose at RPV 1T and Concrete ID Locations ........... 28

Table 4-1: Concrete Layers Composition for Sample PWR ..................................32

Table 4-2: MCNP5 Results for 2-Loop Model ................................................ 33

Table 4-3: ORNL Results for 2-Loop Model [6] ............................................ 34

Table 4-4: Neutron Flux Attenuation (n/ $\mathrm{cm}^{2} \mathrm{~s}$ - normalized per source neutron) with

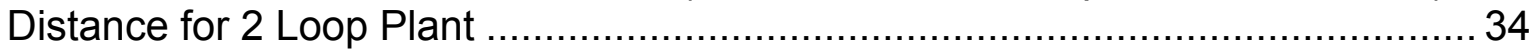

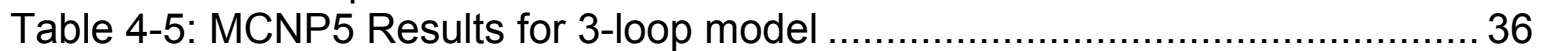

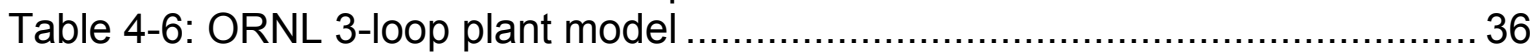

Table 4-7: TwE 3-loop plant model ............................................................. 36

Table 4-8: Neutron Flux $\left(\mathrm{n} / \mathrm{cm}^{2} \mathrm{~s}\right.$ - normalized per source neutron) attenuation in

Portland concrete (3-loop) .................................................................. 37

Table 6-1: Typical Portland Cement Elements (weight).................................... 63

Table 6-2: Special aggregates for radiation-shielding concrete .......................... 64

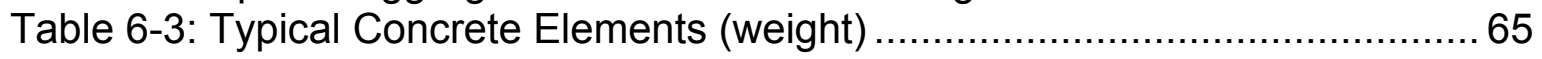

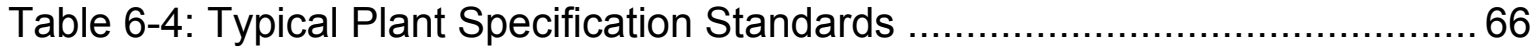

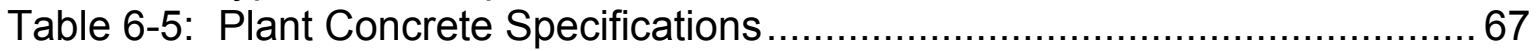




\section{INTRODUCTION}

An important topic for long term operation of nuclear plants is aging of plant concrete structures. The containment building, biological shielding, and support concrete are examples of concrete structures that are of primary importance in the operation of a nuclear plant. These and other safety related structures at a plant site must be capable of maintaining structural capability for the operating life of the plant. In fact, degradation of the concrete may provide a basis for early shutdown of a nuclear plant. Demonstration of the satisfactory condition of the concrete structures is required for operation of the plant, particularly when plant operation beyond 60 years is considered.

The objective of this project was to perform work and issue a report that defines the expected condition of concrete at an age of 80 years.

\subsection{Background}

The operation of a nuclear power plant to an age of 80 years will require the study of aging and possible degradation of concrete structures residing in high radiation fields. The critical concrete structures of interest for most plants include the primary containment building and the biological shield walls (also called the reactor cavity concrete). These are shown in Figures 1-1 and 1-2 for a PWR and a BWR respectively. The biological shield wall concrete structure surrounds the nuclear reactor pressure vessel and provides the essential radiation shielding to the surrounding environment. The biological shield wall will experience the highest radiation exposure. In many plant designs, the biological shield wall is also a load-bearing structure that supports the reactor pressure vessel.

The degradation of the structural capability of the biological shield wall can be affected by two primary mechanisms: elevated thermal temperatures during reactor operation and nuclear radiation. Elevated temperatures inside and outside the biological shield wall can degrade concrete structures by accelerating the depletion, or vaporization, of the moisture content in the concrete. High radiation dose due to neutron and gamma bombardment can damage concrete structures by changing the material characteristics when collisions with radiation particles occur and by increasing the temperature of the concrete.

Monitoring thermal temperatures in the plant can be performed using thermocouples or other temperature measuring devices. Temperatures of the air moving past the inside surface of the biological shield wall can be 


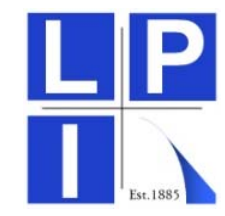

determined. With the use of thermodynamic analysis, temperature profiles throughout the concrete structures can be calculated.

Monitoring radiation energies and the resulting damage to concrete materials throughout the biological shield wall is not as well defined as determining temperature profiles. Radiation levels that are routinely tracked for the reactor vessel can be used to define the radiation at the inside of the biological shield wall. The attenuation of the radiation then can be calculated and the impact on the concrete properties assessed. The effects of radiation that can increase the temperature of the concrete can also be calculated

\subsection{Scope}

The purpose and scope of this investigation is to provide information on the expected levels of radiation during operation of nuclear power plants to 80 years for the biological shield wall surrounding the reactor. This work does not provide a plant-by-plant qualification, but uses the plants in the US fleet to calculate an expected radiation level at 80 years. Specific data is presented to allow a plantspecific evaluation to be performed. This report also provides recommendations for testing and consideration of other issues that may be useful to supplement existing information.

\subsection{Process Utilized}

The process that has been utilized in performing the work for this report was initiated by determining the neutron and gamma radiation levels that will be experience in the concrete to 80 years of operation. This was done with a multistep process. First, reactor vessel data that has been reported to the NRC was collected. This data was extrapolated to a reactor vessel fluence at an operating life of 80 years. This data is commonly reported for the inside diameter (ID) of the vessel or the region of the vessel near the ID. The fluence that is reported at the ID of the vessel was then attenuated from the ID wall to the vessel outside diameter (OD) wall. Reactor vessel data is tabulated for an energy level greater than $1.0 \mathrm{MeV}$. Analyses are then used to define a ratio between the vessel OD fluence at $0.1 \mathrm{MeV}$ and $1.0 \mathrm{MeV}$. This ratio depends on the thickness of the vessel. Once the fluence at the vessel OD is determined, it is the translated to the ID of the concrete. This is then defined as the maximum fluence that is expected to exist in the concrete. The gamma exposure was determined by utilizing analyses that have been performed that determined the gamma levels at the inside surface of the concrete. 
The test data that is available for the effects of radiation on concrete was also reviewed and summarized. This data could be used in comparison with the radiation levels at specific locations to define the expected capabilities of the concrete at 80 years of operations.

The attenuation through the concrete is important for the evaluation of the critical locations in the biological shield wall. The attenuation was calculated using neutron and gamma transport codes to simulate particle interactions with the concrete material. This was done for just concrete and for concrete with reinforcing steel in it.

The range of concrete materials used in biological shield walls and the functional requirements of the biological shield wall concrete were then assessed in order to define critical regions and requirements for the concrete in the wall. This characterization of the critical locations of the biological shield walls was then used with the maximum fluence, the attenuation expected, and the test data to determine the condition of the concrete that should be expected at 80 years of operation. 


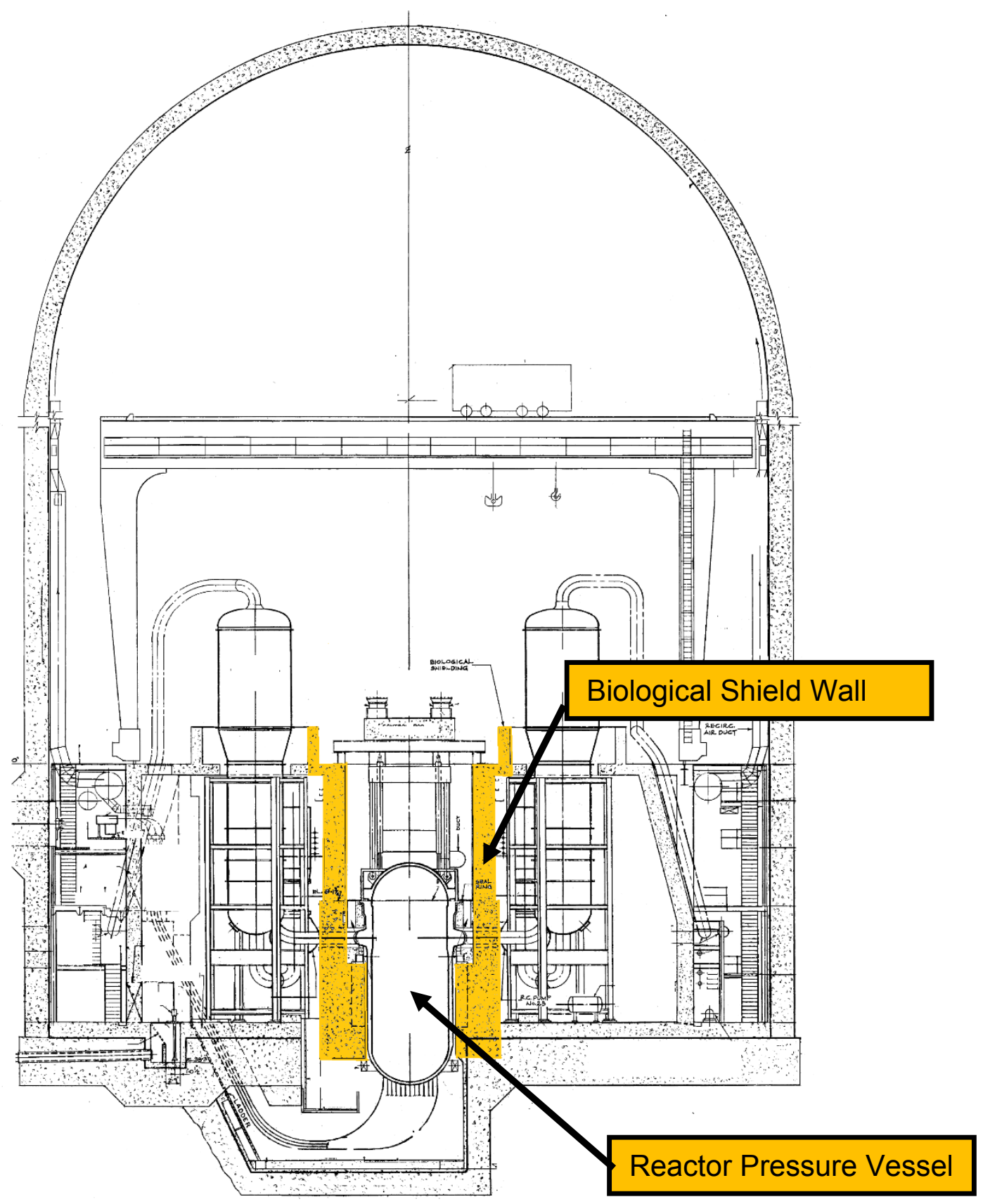

Figure 1-1: Typical Configuration of PWR RPV and Biological Shield Structure 


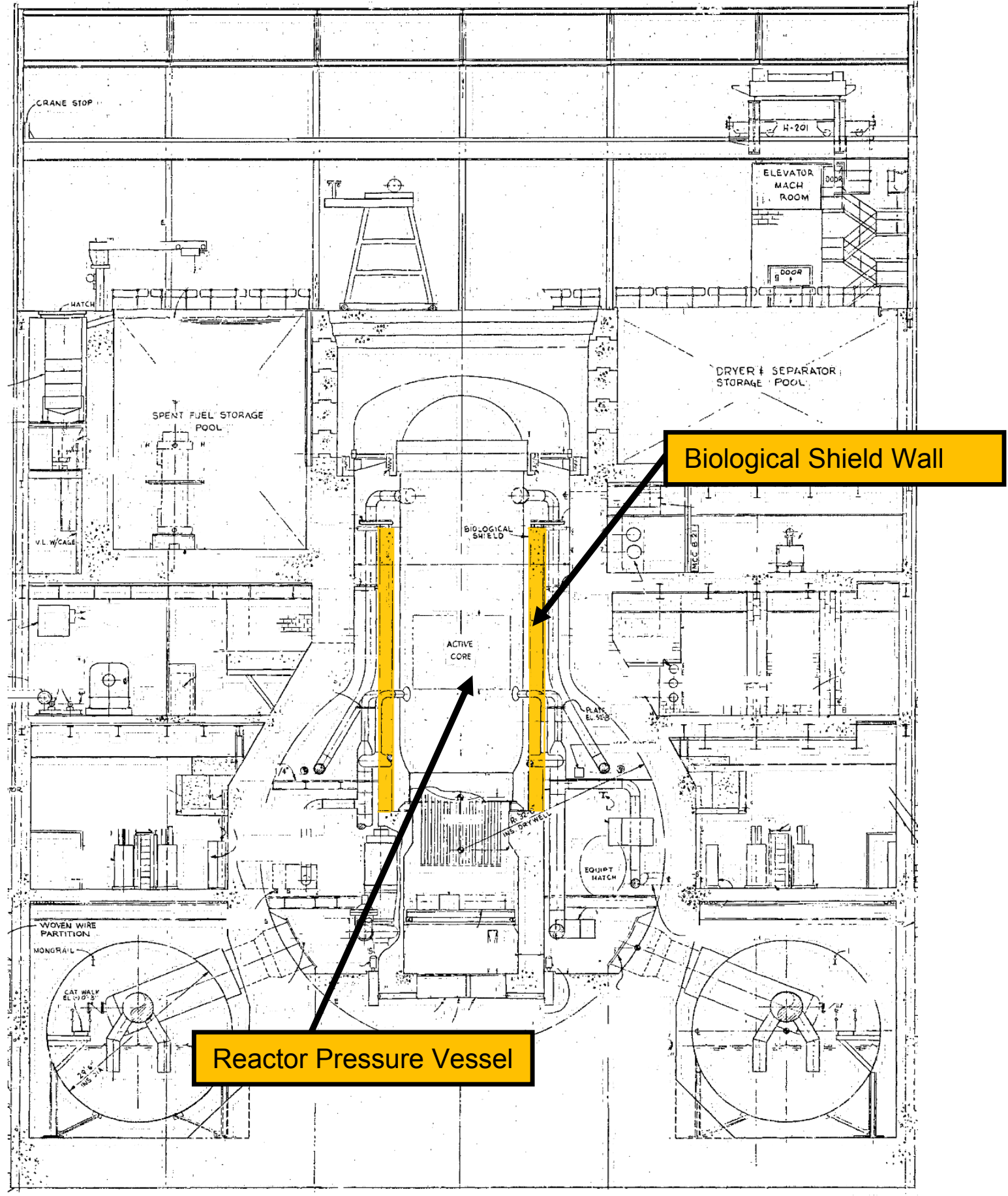

Figure 1-2: Typical Configuration of BWR RPV and Biological Shield Structure 


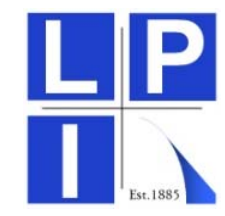

\section{INPUT CONSIDERATIONS}

This study assesses concrete of typical biological shield walls at US fleet reactors, this study is based on the following parameters:

1. Concrete. The design of typical biological shield wall concrete at currently operating US commercial nuclear reactors typically utilize ordinary Portland cement concrete of normal density (150 pounds per cubic foot). Typically, no additional aggregates or constituents, occasionally added to increase density and thus enhance shielding performance, such as Hematite $\left(\mathrm{Fe}_{2} \mathrm{O}_{3}\right)$, Ilmenite $(\mathrm{FeO}$ $\left.\mathrm{TiO}_{2}\right)$, Magnetite $\left(\mathrm{Fe}_{3} \mathrm{O}_{4}\right)$ and Steel Aggregate are included. This was validated as typical based on a review of a sample of currently operating relatively "early" vintage plants for the design specification of concrete in their biological shield walls. One operating plant was identified that used high density aggregate. Specifications for the concrete in all plants in the US fleet were not available and were not reviewed. Specific information for a plant would need to be considered on a case-by-case basis.

2. Steel. The concrete steel reinforcement considered in the shield walls is considered to be carbon steel. This is typical for currently operating US commercial nuclear reactors.

3. Neutron Shielding. Certain plants have incorporated neutron shields within the reactor cavity (i.e. space between the RPV and the inside face of the shield wall). This will generally decrease the level of neutron exposure in the concrete. The calculation of neutron fluence presented in this report does not take any neutron shielding between the reactor vessel and the concrete into account. This is considered conservative for development of a bounding value.

4. Operating Years: The study is based on operating a nuclear reactor for a period of 80 years. Neutron fluence is reported by licensees to the NRC, based on Effective Full Power Years (EFPY) which considers the actual duration of time when the reactor is critical, and neutron radiation is present.

5. Capacity Factor. Capacity Factor (CF) is used as a measure to extrapolate an EFPY of operation over 80 years. A value of CF of $92 \%$ is utilized to project availability and hence reactor operation over the life of the reactor. This value results in an operating time of $0.92 \times 80$ years $=73.6$ years. This is used as an EFPY for each reactor in this study. Actual EFPY at any given reactor, if it were to operate for 80 years, would be expected to have an EFPY that is approximately at or lower than this value.

Report No. A13276-R-001

Page 13 of 92

Revision 0 
6. Reported Fluence Values. Each licensee reports an expected fluence level for an EFPY expected at their current end-of-life, to the US NRC. This reported value considers the reactors prior availability, likely future availability, and consideration of prior fuel loading campaigns. Improvements in fuel design, and "low leakage" fuel arrangements have generally resulted in current lower levels of fluence in any operating cycle in comparison to early years. The prior reported fluence levels have incorporated data from the earlier years of operation. This consideration combined with generally lower capacity factors in early years of operation than considered for the study, will result in a reasonably accurate value when linear extrapolation is used to get to an EFPY of 73.6 years.

7. Energy Levels: The neutron fluence calculated will be for energy greater than $0.1 \mathrm{MeV}$. For concrete, research teams around the world have selected and standardized on a neutron energy greater than $0.1 \mathrm{MeV}$. This energy level is considered to represent the energy that will cause damage in concrete. An energy level of $0.1 \mathrm{MeV}$ will provide a useful basis for comparison to other analyses and tests.

8. Containment Temperature: Containment temperature, specifically the temperature of the concrete at the inside surface of the shield wall is considered to be at $150^{\circ} \mathrm{F}$. This is based on forced cooling that occurs in most plants to ensure that concrete temperatures remain below this threshold. 


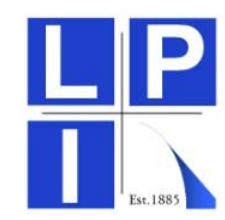

\section{RADIATION EXPOSURE}

Radiation exposure to the biological shield wall is associated with neutron and gamma bombardment. To assess levels of neutron radiation for the plants within the scope of this study, reactor fluence levels reported by licensees to the US NRC were utilized. Data for both PWR and BWR plants was obtained based on reports obtained from ADAMS. This data, typically reported for a presented number of effective full power years (EFPY) was then extrapolated to levels associated with 80 years of plant operation, as outlined in Section 2.0.

The reactor pressure vessel (RPV) data, which is associated with damage assessment of the RPV is presented in the reports at energy levels greater than $1.0 \mathrm{MeV}$. As such, the calculated values are then extrapolated to determine the radiation levels at energy levels greater than $0.1 \mathrm{MeV}$. The use of energy levels of $\mathrm{E}>0.1 \mathrm{MeV}$ to assess concrete damage is consistent with the approach used by others (see Fujiwara [1] ${ }^{1}$ and Kontani [2] as example), as outlined in Section 2.0.

In order to extrapolate the energy levels from the OD of the RPV to the ID of the Shield Wall, attenuation methods outlined in US NRC Regulatory Guide 1.99 [3], [4] are utilized. This approach was validated based on study results from computational models [5], [6].

Analyses performed by TransWare Enterprises (TwE) [5], supplemented by ORNL analyses [6] [10] and an EPRI assessment [7], will be utilized for an indication of gamma radiation at the concrete. The heating effect of the gamma radiation will also be determined. The objective will be to develop an envelope of the radiation (neutrons with energy greater than $0.1 \mathrm{MeV}$ and gamma) at the biological shield wall for US fleet plants will be developed through 80 years. The neutron and gamma radiation at various depths into the concrete will also be calculated. The heating of the concrete will also be defined.

\subsection{Radiation in Concrete}

The neutron and gamma radiation at the surface of the concrete must be determined. This will be calculated for the equivalent of 80 years of operation.

The energy for the neutron fluence will be for energy greater than $0.1 \mathrm{MeV}$. The reactor vessel is assessed for energy levels greater than $1.0 \mathrm{MeV}$. For concrete, research teams around the world have selected and standardized on a neutron energy greater than $0.1 \mathrm{MeV}$. That energy level will be used in this study. An energy level of $0.1 \mathrm{MeV}$ will provide a useful basis for comparison to other

${ }^{1}$ Numbers in [ ] refer to references listed in Section 10.

Report No. A13276-R-001

Revision 0

Page 15 of 92 


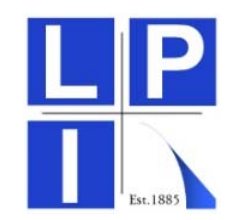

analyses and tests, but care should be taken to consider thermal neutrons also in detailed testing or comparison of concrete capabilities.

A multi-step process has been used to determine the fluence in the concrete. First, reactor vessel data that is reported to the NRC has been retrieved. This is extrapolated to an operating life of 80 years and then attenuated from the ID wall to the vessel OD wall. This is for an energy of $1.0 \mathrm{MeV}$. Analyses are then used to define a ratio between the vessel OD fluence at $0.1 \mathrm{MeV}$ and $1.0 \mathrm{MeV}$. This depends on the thickness of the vessel. Once the fluence at the vessel OD is determined, it is translated to the ID of the concrete. This is the maximum fluence that exists in the concrete.

The attenuation through the concrete is then calculated to determine the fluence at critical locations in the shield wall.

\subsection{Neutron Fluence in RPV}

\subsubsection{Fluence at RPV OD (E > 1.0 MeV)}

Current licensee reports to the US NRC provide values of expected fluence levels in-terms of EFPY through to the current operating license (i.e. 40 or 60 years). These values have incorporated the availability of the reactor (i.e. considered as the Capacity Factor for this study), and consideration of fluence per operating cycle with changing fuel design and loading campaigns. The reported values are for $E>1.0 \mathrm{MeV}$, and are typically at the inside diameter location of the RPV. This location is referred to as the "OT" location in this study. The reported values are presented for a reported EFPY. This data is then extrapolated linearly to derive fluence for the study period 73.6 EFPY.

To derive the expected fluence at the outside diameter of the RPV, referred to herein as the "1T" location, the attenuation equation in US NRC Regulatory Guide 1.99 [4] is utilized. Equation 2 of the Regulatory Guide provides an equation that is based on displacement per atom (dpa) attenuation factors. As identified in [8], the early basis for attenuating fluence utilized a different form of the equation. Where the exponent factor based on dpa attenuation was $-0.24 x$, for fluence attenuation, the exponent is $-0.33 x$ ( $x$ is the vessel thickness in inches). Thus, an appropriate equation for determination of fluence attenuation through the thickness of the RPV would be:

Report No. A13276-R-001

Revision 0

Page 16 of 92 


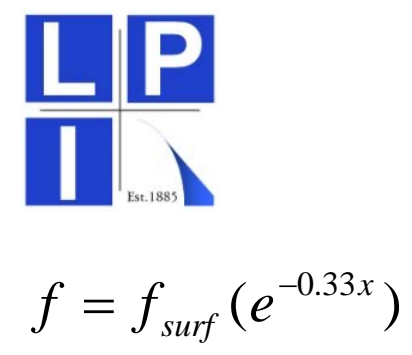

Where:

$$
\begin{aligned}
& f=\text { neutron fluence }\left(\mathrm{n} / \mathrm{cm}^{2}\right) \text { at the outside surface }(1 \mathrm{~T}) . \\
& f_{\text {surf }}=\text { neutron fluence }\left(\mathrm{n} / \mathrm{cm}^{2}\right) \text { at the inner (wetted) surface }{ }^{2}(0 \mathrm{~T}) . \\
& x=\text { thickness of RPV }
\end{aligned}
$$

To support the use of this equation, calculated values from selected reports were evaluated to assess the value of the exponent. This assessment is shown in Table 3-1, and supports the use of the modified attenuation equation with an exponent of -0.33 . In an ORNL analysis [9], three different vessel thicknesses were analyzed and are referred to as "thinnest", "medium", and "thick".

The assessment for each US plant was performed as outlined above and shown in Attachment A. The results for PWRs and BWRs are summarized in Figure 3-1 and Figure 3-2, respectively.

Based on this evaluation, the bounding values of fluence at the RPV outer wall (1T) location for 80 years of reactor operation (EFPY of 73.6 years), was determined to be:

- PWR, $9.0 \mathrm{E}+18 \mathrm{n} / \mathrm{cm}^{2}$ (E > 1.0 MeV)

- $\quad$ BWR, $2.1 \mathrm{E}+18 \mathrm{n} / \mathrm{cm}^{2}(\mathrm{E}>1.0 \mathrm{MeV})$

2 The inner wall typically contains a cladding, with the wetted surface being the inside of the cladding. The provided wall thickness in the reports extracted from Adams, may or may not include the cladding. Ignoring the cladding thickness is considered to be conservative. 
Table 3-1: Assessment of Flux Attenuation Equation (E > 1.0 MeV)

\begin{tabular}{|l|c|c|c|c|}
\hline \multicolumn{1}{|c|}{ Study } & $\begin{array}{c}\mathrm{f}_{0 \mathrm{~T}} \\
\left(\mathrm{n} / \mathrm{cm}^{2} \text {-sec }\right)\end{array}$ & $\begin{array}{c}\mathrm{f}_{1 \mathrm{~T}} \\
\left(\mathrm{n} / \mathrm{cm}^{2} \text {-sec) }\right.\end{array}$ & $\begin{array}{c}\text { RPV } \\
\text { Thickness } \\
\text { (in) }\end{array}$ & Exponent \\
\hline 3-Loop ORNL [6] & $2.50 \mathrm{E}+10$ & $1.04 \mathrm{E}+09$ & 9.5 & 0.335 \\
\hline 3-Loop TwE [5] & $3.46 \mathrm{E}+10$ & $1.31 \mathrm{E}+09$ & 9.5 & 0.345 \\
\hline 2-Loop ORNL [6] & $3.60 \mathrm{E}+10$ & $3.58 \mathrm{E}+09$ & 6.5 & 0.355 \\
\hline $\begin{array}{l}\text { "Thinner vessel" } \\
\text { ORNL [9] }\end{array}$ & $3.04 \mathrm{E}+10$ & $2.63 \mathrm{E}+09$ & 7.38 & 0.332 \\
\hline $\begin{array}{l}\text { "Medium thickness" } \\
\text { ORNL [9] }\end{array}$ & $3.04 \mathrm{E}+10$ & $1.23 \mathrm{E}+09$ & 9.53 & 0.337 \\
\hline $\begin{array}{l}\text { "Thickest vessel" } \\
\text { ORNL [9] }\end{array}$ & $3.04 \mathrm{E}+10$ & $5.00 \mathrm{E}+08$ & 11.91 & 0.345 \\
\hline
\end{tabular}

Where:

fot $_{\text {O }}$ RPV Inside Diameter flux

$f_{1 T}-$ RPV Outside Diameter flux 


\section{LIP \\ I.}

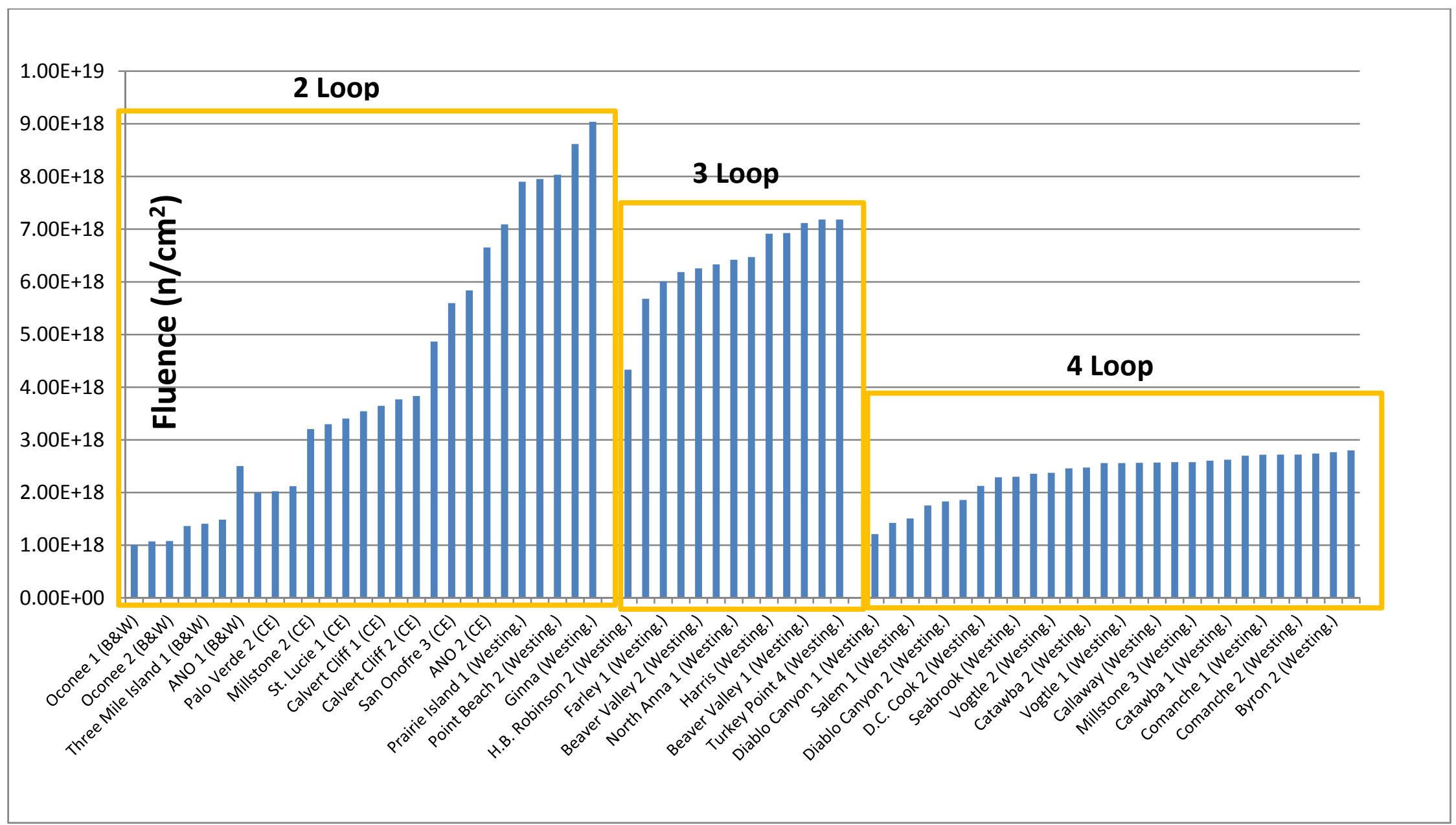

Figure 3-1: Summary of US PWR Fleet Fluence, RPV 1T extrapolated to80 years (E $>1.0 \mathrm{MeV})$ 


\section{LPP \\ I.}

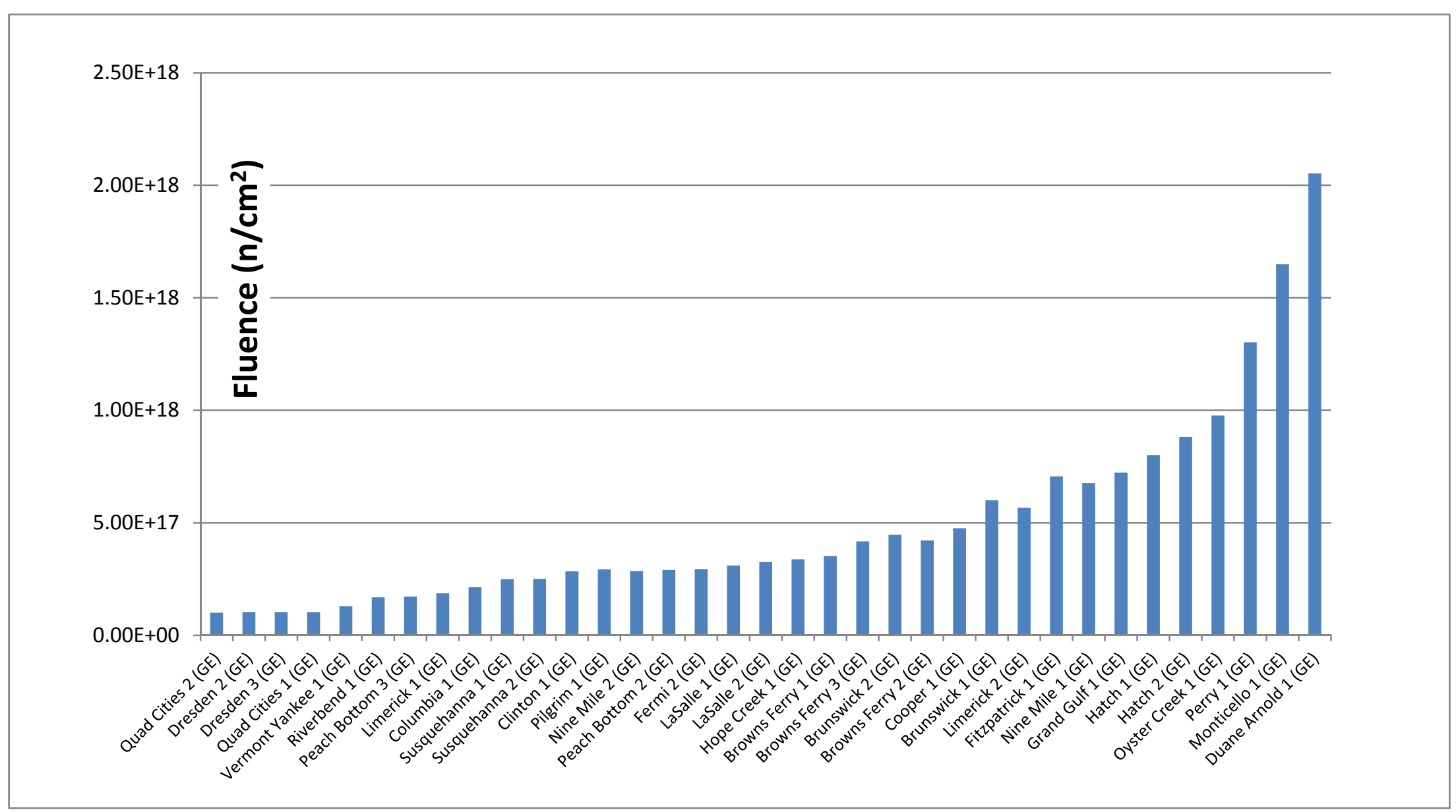

Figure 3-2: Summary of US BWR Fleet Fluence extrapolated to 80 years $(E>1.0 \mathrm{MeV})$ 


\section{LP \\ I 1}

\subsubsection{Fluence at RPV OD (E > 0.1 MeV)}

As described in Section 2.0, many studies of concrete utilize radiation with energy above $0.1 \mathrm{MeV}$. As such it is necessary to convert the resulting fluence calculated at $E>1.0 \mathrm{MeV}$ to that at $\mathrm{E}>0.1 \mathrm{MeV}$. This conversion depends on the reactor vessel wall thickness. Available study data was reviewed [5], [6], [9] from prior assessments. These were correlated to the wall thickness of the evaluated RPV. This is shown in Table 3-2 and Figure 3-3.

The resulting data was then curve fit to an equation as a function of the wall thickness. The resulting RPV 1T location fluence for the US fleet plants is then shown in Figure 3-4 and Figure 3-5 for $\mathrm{E}>0.1 \mathrm{MeV}$.

Based on the work performed, the bounding values of fluence at the RPV outer wall (1T) location for 80 years of reactor operation (EFPY of 73.6 years), was determined to be:

- PWR, $6.8 \mathrm{E}+19 \mathrm{n} / \mathrm{cm}^{2}(\mathrm{E}>0.1 \mathrm{MeV})$

- $B W R, 1.0 \mathrm{E}+19 \mathrm{n} / \mathrm{cm}^{2}(\mathrm{E}>0.1 \mathrm{MeV})$

Table 3-2: Assessment of Increase Ratio for E> 0.1 to E> 1.0 MeV

\begin{tabular}{|l|c|c|c|c|}
\hline \multicolumn{1}{|c|}{ Study } & $\begin{array}{c}\mathrm{fOD} \\
\mathrm{E}>0.1 \mathrm{MeV} \\
\left(\mathrm{n} / \mathrm{cm}^{2}-\mathrm{s}\right)\end{array}$ & $\begin{array}{c}\mathrm{fOD} \\
\mathrm{E}>1.0 \mathrm{MeV} \\
\left(\mathrm{n} / \mathrm{cm}^{2}-\mathrm{s}\right)\end{array}$ & $\begin{array}{c}\text { RPV } \\
\text { Thickness } \\
\text { (in) }\end{array}$ & Ratio \\
\hline 3-Loop ORNL [6] & $1.43 \mathrm{E}+10$ & $1.04 \mathrm{E}+09$ & 9.5 & 13.75 \\
\hline 3-Loop TwE [5] & $1.77 \mathrm{E}+10$ & $1.31 \mathrm{E}+09$ & 9.5 & 13.51 \\
\hline 2-Loop ORNL [6] & $3.04 \mathrm{E}+10$ & $3.58 \mathrm{E}+09$ & 6.5 & 8.49 \\
\hline $\begin{array}{l}\text { "Thinner vessel" } \\
\text { ORNL [9] }\end{array}$ & $1.96 \mathrm{E}+10$ & $2.62 \mathrm{E}+09$ & 7.38 & 7.46 \\
\hline $\begin{array}{l}\text { "Medium thickness" } \\
\text { ORNL [9] }\end{array}$ & $1.50 \mathrm{E}+10$ & $1.23 \mathrm{E}+09$ & 9.53 & 12.21 \\
\hline $\begin{array}{l}\text { "Thickest vessel" } \\
\text { ORNL [9] }\end{array}$ & $1.05 \mathrm{E}+10$ & $5.00 \mathrm{E}+08$ & 11.91 & 21.01 \\
\hline
\end{tabular}



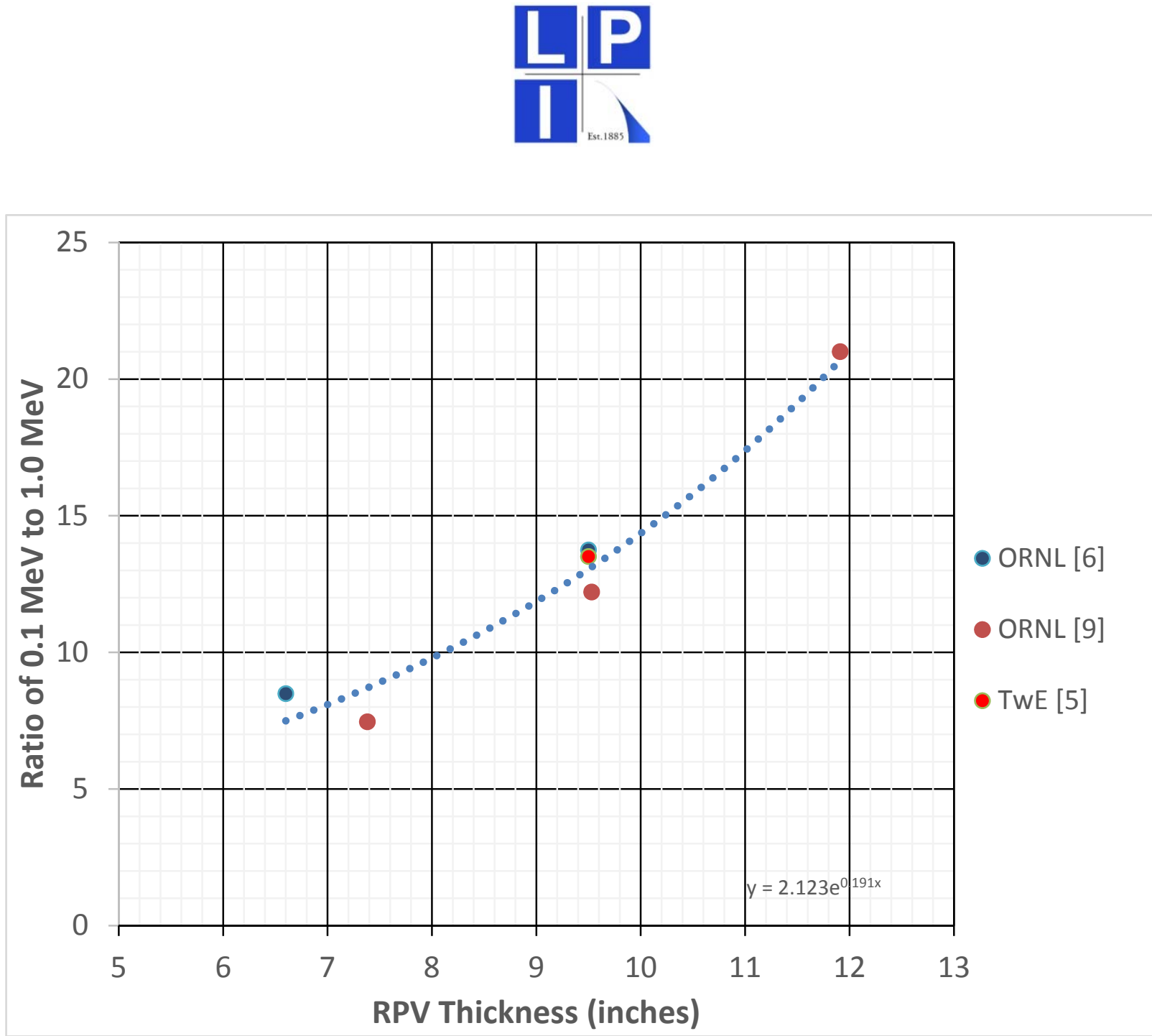

Figure 3-3: Ratio of E> $0.1 \mathrm{MeV}$ to $1.0 \mathrm{MeV}$ vs. RPV Thickness 


\section{LIP \\ I.}

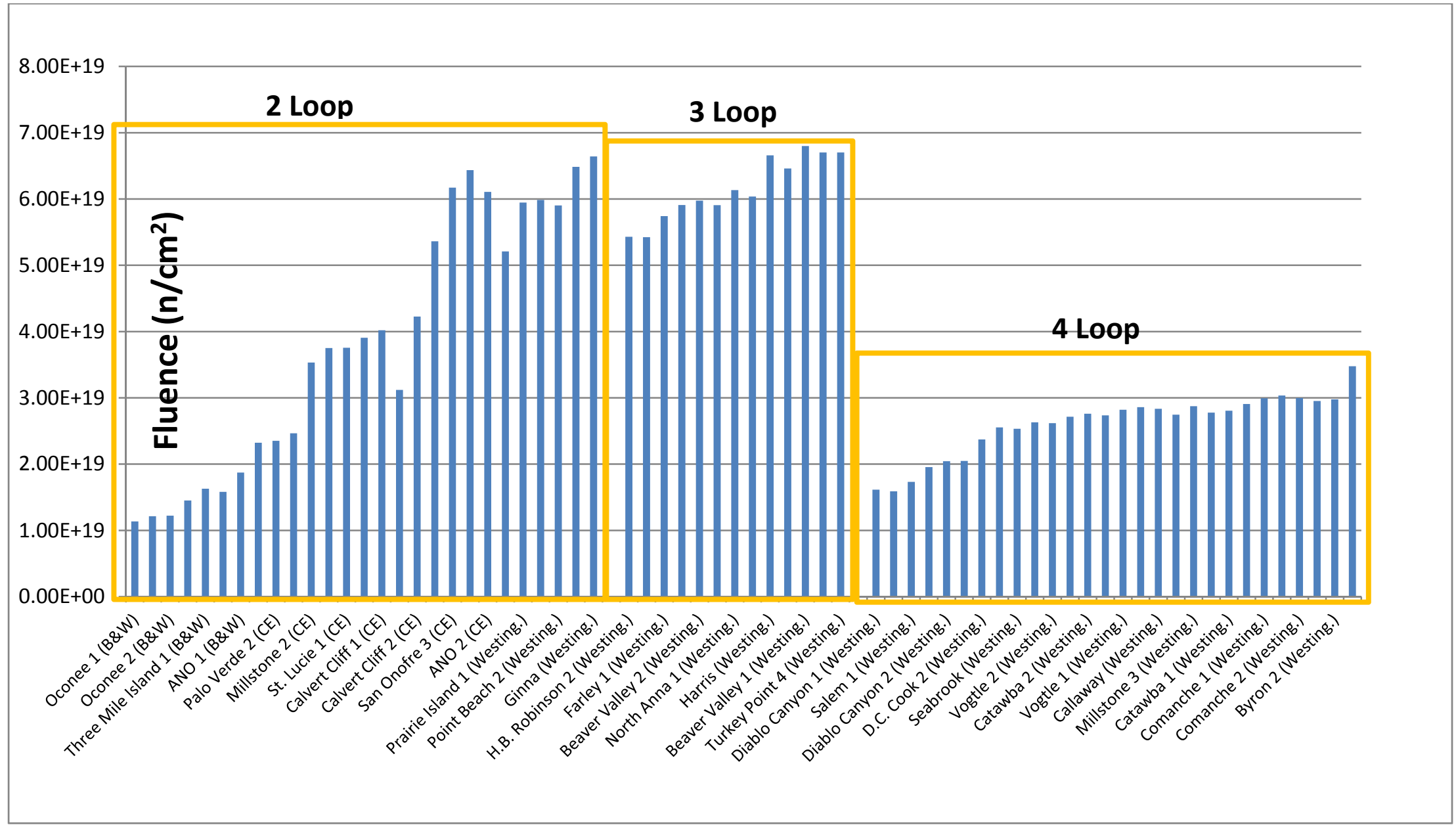

Figure 3-4: Summary of US PWR Fleet Fluence extrapolated to 80 years $(E>0.1 \mathrm{MeV})$ 


\section{LPP I.}

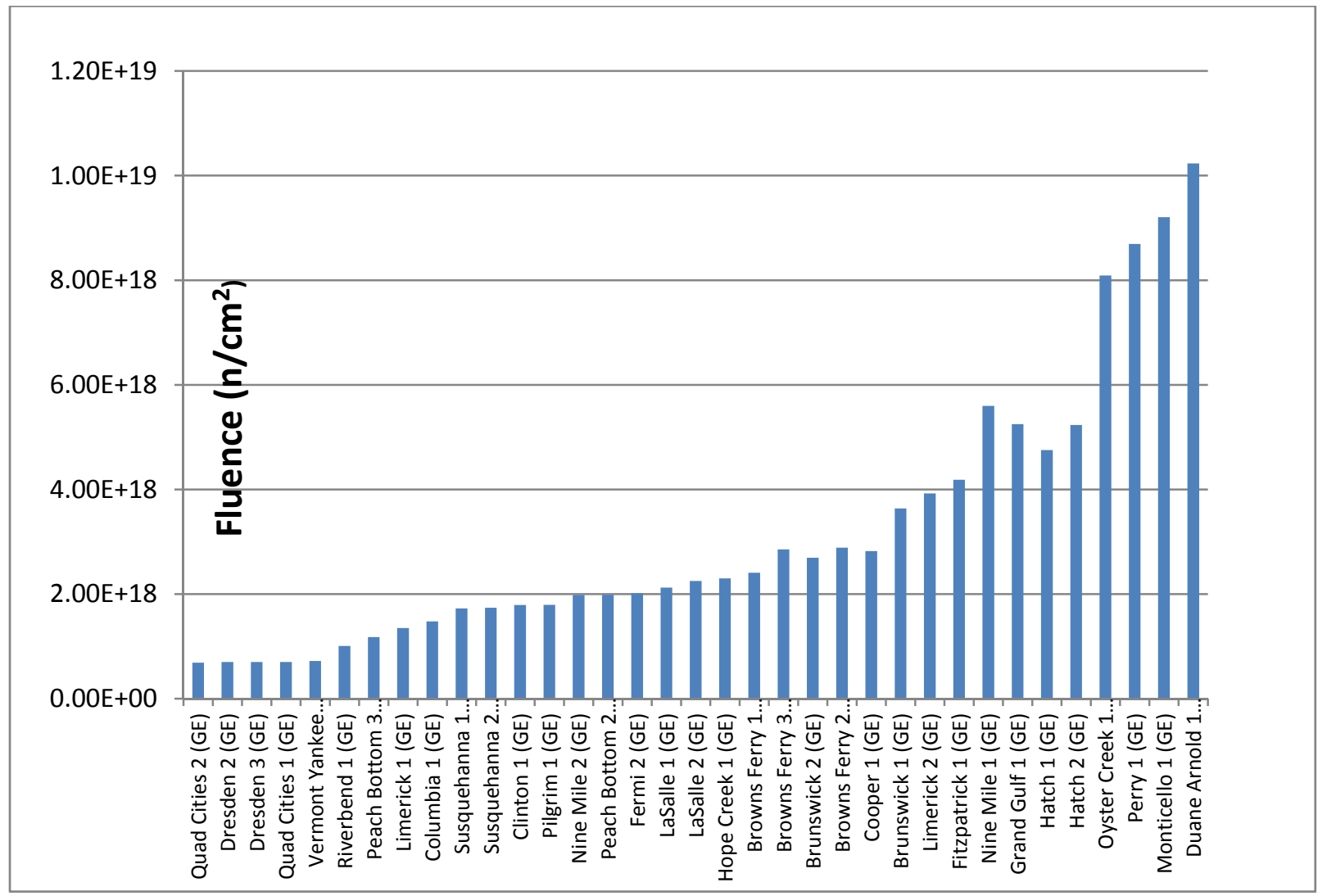

Figure 3-5: Summary of US BWR Fleet Fluence extrapolated to 80 years $(E>0.1 \mathrm{MeV})$ 


\subsubsection{Neutron Flux Variation along Active Fuel}

As part of the study performed by TwE for the 3-loop plant [5], flux variation along the active fuel length was investigated. For regions of concrete located away from the core mid height, the resulting fluence will be lower. This is important to regions for concrete providing support to the RPV, which for many PWRs are located away from the core mid height. The neutron flux was normalized to the maximum flux within the belt-line region. The normalized neutron flux is shown in Figure 3-6. Note the rapid reduction in flux above and below the core belt-line.

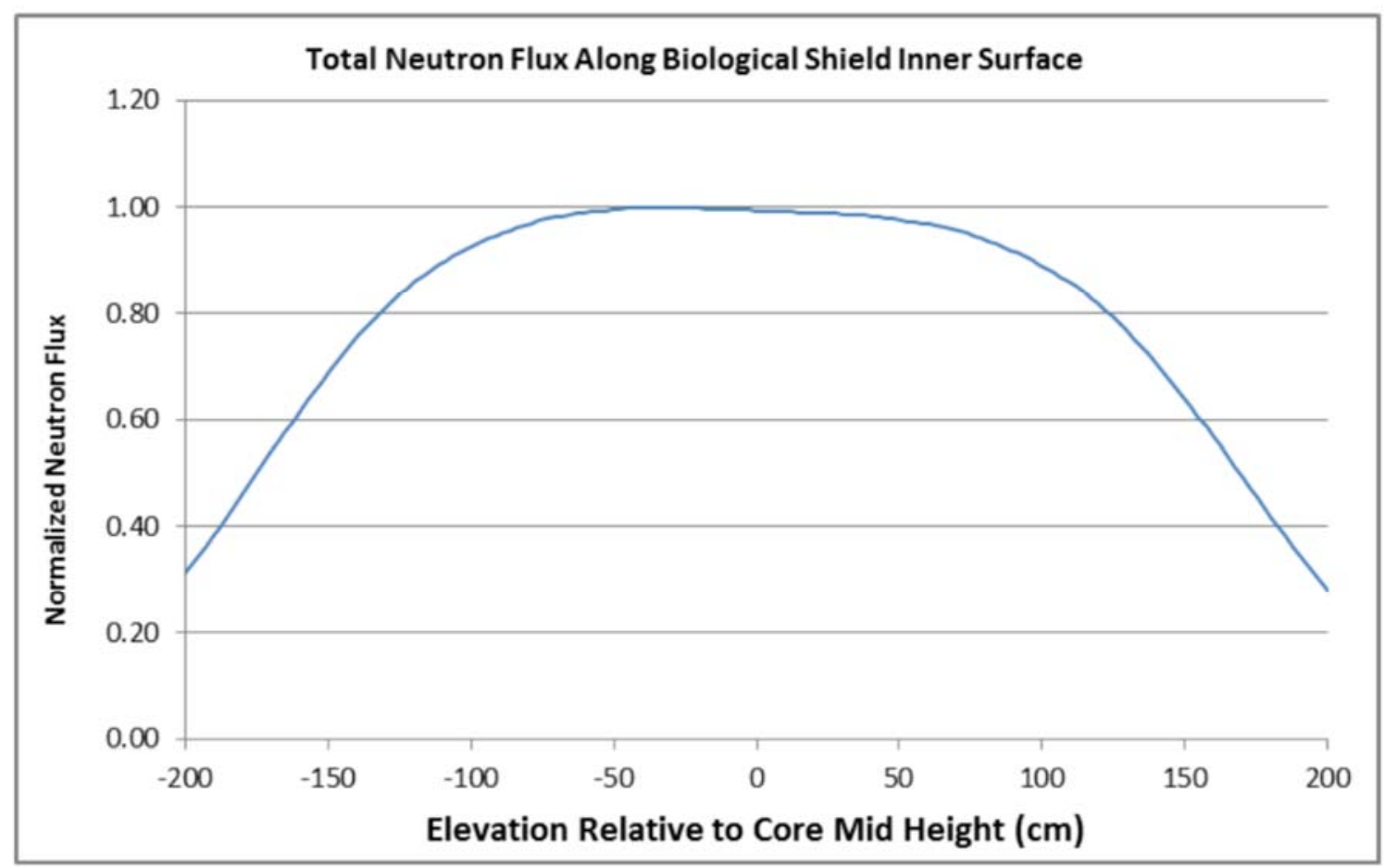

Figure 3-6: Axial Neutron Flux Variation Relative to Core Fuel Mid-Height

\subsection{Fluence at ID of Concrete}

With the fluence at the OD of the vessel (RPV 1T location), the fluence at the ID of the concrete can be calculated. The fluence with $E>0.1 \mathrm{MeV}$ at the ID of the concrete is lower than the OD of the vessel. This is primarily due to the gap that exists between the OD of the vessel and the ID of the concrete. Analyses by TwE [5] and ORNL [6] were used to compare the vessel OD to the concrete ID. Both locations were calculated in each analysis for $E>0.1 \mathrm{MeV}$ for a 
Westinghouse two loop and a Westinghouse three loop plant. The results are shown in Table 3-3.

These analyses show a ratio of the Concrete ID fluence to the Vessel OD fluence of between 0.79 and 0.89 . A ratio of 0.9 will be used for this evaluation. The fluence that is at the vessel OD will be reduced by $10 \%$ to obtain the concrete ID fluence.

Table 3-3: Ratio of Flux at ID of Concrete vs. OD of PWR RPV (E > $0.1 \mathrm{MeV})$

\begin{tabular}{|c|c|c|c|}
\hline Study & $\begin{array}{c}\text { Vessel foD } \\
\left(\mathbf{n} / \mathbf{c m}^{2} \text {-s }\right)\end{array}$ & $\begin{array}{c}\text { Concrete fid } \\
\left(\mathbf{n} / \mathbf{c m}^{2} \text {-s) }\right.\end{array}$ & Ratio \\
\hline 3-Loop ORNL [6] & $1.43 E+10$ & $1.13 E+10$ & 0.79 \\
\hline 3-Loop TwE [5] & $1.77 E+10$ & $1.57 E+10$ & 0.89 \\
\hline 2-Loop ORNL [6] & $3.04 E+10$ & $2.41 E+10$ & 0.79 \\
\hline
\end{tabular}

\subsection{Enveloping Fluence in Concrete}

\subsubsection{Neutron Fluence - 2 Loop Plant}

A Westinghouse two loop plant has been projected to have the highest reactor vessel $O D$ fluence after 80 years of operation. This fluence value is $9.0 \mathrm{E}+18 \mathrm{n} / \mathrm{cm}^{2}$ at $\mathrm{E}>1.0 \mathrm{MeV}$ at the vessel $\mathrm{OD}$ (see Figure 3-1). This plant has a reactor vessel wall thickness of 6.5 inches. For that vessel thickness, the ">0.1 MeV to $>1.0 \mathrm{MeV}$ ratio" is 7.5. The fluence with $\mathrm{E}>$ $0.1 \mathrm{MeV}$ at the RPV OD is then $6.8 \mathrm{E}+19 \mathrm{n} / \mathrm{cm}^{2}$ (see Figure 3-4). The fluence at the concrete ID is $10 \%$ less than the vessel OD, so that the fluence with $E>0.1 \mathrm{MeV}$ at the concrete ID will be $6.1 \mathrm{E}+19 \mathrm{n} / \mathrm{cm}^{2}$ for 80 years of operation.

\subsubsection{Neutron Fluence - 3 Loop Plant}

A Westinghouse three loop plant has been projected to have the highest three loop plant reactor vessel OD fluence after 80 years of operation. This fluence was lower than the two loop plant but the plant has a different vessel thickness. This fluence value is $7.1 \mathrm{E}+18$ at $\mathrm{E}>1.0 \mathrm{MeV}$ at the vessel OD for 80 years of operation (see Figure 3-1). This plant has a reactor vessel wall thickness of 7.874 inches. For that thickness, 


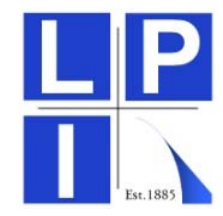

the ">0.1 MeV to $>1.0 \mathrm{MeV}$ ratio" is 9.55 . The fluence with $\mathrm{E}>0.1 \mathrm{MeV}$ at the RPV OD is then $6.8 \mathrm{E}+19 \mathrm{n} / \mathrm{cm}^{2}$ (see Figure 3-4). The fluence at the concrete ID is $10 \%$ less than the vessel OD, so that the fluence with $\mathrm{E}>0.1 \mathrm{MeV}$ at the concrete ID will be $6.1 \mathrm{E}+19 \mathrm{n} / \mathrm{cm}^{2}$ for 80 years of operation. This is the same as in the limiting two loop plant.

\subsubsection{Enveloping Neutron Fluence - US Fleet}

The four loop plants have less than half as much fluence at the vessel OD than the three loop plants (Figure 3-1, Figure 3-4) and are not limiting. The BWR vessels (Figure 3-2, Figure 3-5) are also lower than the four loop plants and are not limiting.

On that basis, a value of $6.1 \mathrm{E}+19 \mathrm{n} / \mathrm{cm}^{2}(\mathrm{E}>0.1 \mathrm{MeV})$ for 80 years of operation appears to bound the US fleet.

\subsection{Gamma Radiation}

Determination of gamma flux and resulting dose rate are available from study evaluations by ORNL on 2-loop and 3-loop Westinghouse plants [6] and from TwE on a 3-loop Westinghouse plant [5], at the surface of the concrete, and attenuated into the concrete. An additional analysis was available for a reference 4-loop PWR and a BWR Mark 6 reactor by EPRI [7], for gamma flux at the 1T RPV location. Additionally a determination of gamma flux distribution in the pressure vessel and cavity of a BWR Mark 6 reactor by ORNL was available [10]

Selected results are summarized in Table 3-4. It is apparent from the gamma dose for the two reference plants considered in the EPRI study [7], that the PWR dose exceeds the BWR plant dose. Since the EPRI study PWR gamma dose is comparable to that of the estimates from ORNL and TwE for the PWR plants studies, gamma dose from BWR plants are not expected to be greater than the PWRs.

As part of the study performed by TwE for the 3-loop plant [5], gamma flux variation along the active fuel length was investigated, Figure 3-7. For regions of concrete located away from the core mid-height, the resulting dose will be lower. This is considered important for those regions of concrete providing support to the RPV, which for BWRs and many PWRs are located away from the core mid-height.

Report No. A13276-R-001

Revision 0

Page 27 of 92 
From these studies, the maximum gamma dose at the ID of the concrete is approximately $1.23 \mathrm{E}+10$ rads.

Table 3-4: Gamma Flux and Dose at RPV 1T and Concrete ID Locations

\begin{tabular}{|c|c|c|c|c|c|}
\hline Study & $\begin{array}{c}\text { RPV 1T } \\
\text { Gamma Flux } \\
\text { (photons/cm2-s) }\end{array}$ & $\begin{array}{c}\text { RPV 1T } \\
\text { Dose Rate } \\
\text { (Rad/s) }\end{array}$ & $\begin{array}{c}\text { Shield Wall ID } \\
\text { Dose Rate } \\
\text { (Rad/s) }\end{array}$ & $\begin{array}{c}\text { RPV 1T } \\
\text { Dose } \\
\text { (Rad) }\end{array}$ & $\begin{array}{c}\text { Shield Wall } \\
\text { ID } \\
\text { Dose } \\
\text { (Rad) }\end{array}$ \\
\hline $\begin{array}{c}\text { 3-Loop ORNL } \\
{[6]}\end{array}$ & $3.29 \mathrm{E} 09$ & 2.15 & 2.0 & $5.42 \mathrm{E} 09$ & $5.04 \mathrm{E} 09$ \\
\hline $\begin{array}{c}\text { 3-Loop TwE } \\
{[5]}\end{array}$ & $7.82 \mathrm{E} 09$ & 6.27 & 4.83 & $1.58 \mathrm{E} 10$ & $1.21 \mathrm{E} 10$ \\
\hline $\begin{array}{c}\text { 2-Loop ORNL } \\
{[6]}\end{array}$ & $9.53 \mathrm{E} 09$ & 5.87 & 4.9 & $1.48 \mathrm{E} 10$ & $1.23 \mathrm{E} 10$ \\
\hline $\begin{array}{c}\text { BWR } \\
\text { ORNL [10] }\end{array}$ & --- & 2.77 & 1.695 & $6.98 \mathrm{E} 09$ & $4.27 \mathrm{E} 09$ \\
\hline
\end{tabular}

For Gamma Dose:

Time: $60 \mathrm{sec} \times 60 \mathrm{~min} \times 24 \mathrm{hrs}$. $\times 365$ days $\times 80$ years $=2.52 \mathrm{E}+09$ seconds

Dose: Dose Rate $x$ Time

CF: Conservatively not considered for calculating gamma dose. 

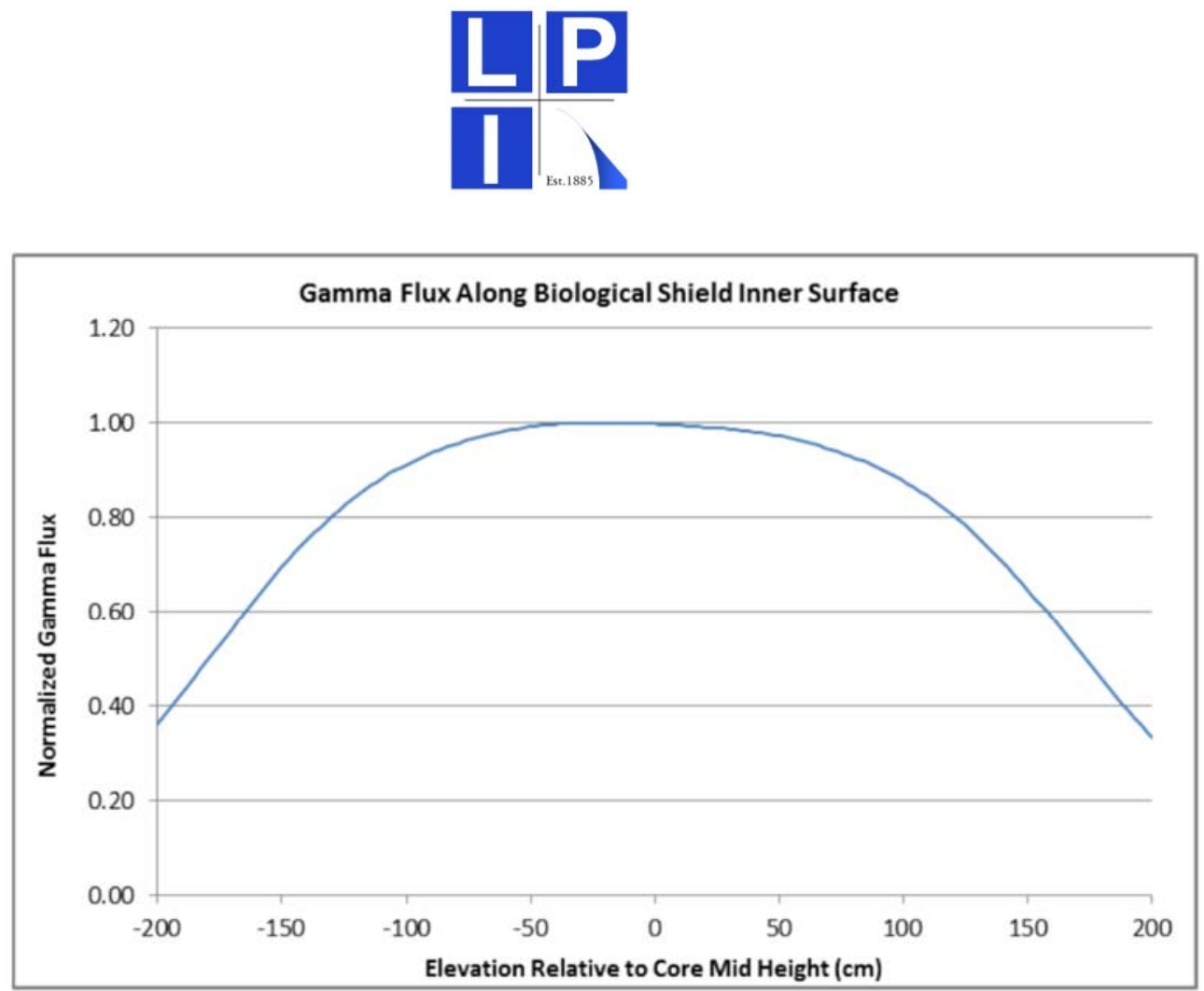

Figure 3-7: Axial Gamma Flux Variation Relative to Core Fuel Mid-Height 


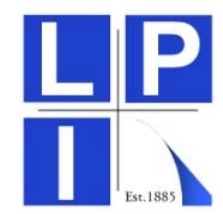

\section{RADIATION ATTENUATION AND HEATING IN CONCRETE}

Simplified models for 2-loop and 3-loop pressurized water reactors were developed using the MCNP5 [11] code. The models were run for concrete constructed with Portland cement ("Portland concrete"). The Portland concrete properties were as defined in a PNNL report [12]. The models were run to determine both neutron and gamma attenuation through the concrete. A typical reactor cavity design will have just concrete in the region nearest the reactor vessel. The depth of just concrete will depend on the rebar cover that is specified in the design for the plant. After that depth of concrete, there will be rebar. The rebar has the potential to affect the attenuation or production of neutron and gamma radiation. To assess the effect of the rebar, a rebar configuration from a commercial plant that is in operation was taken and inserted into the model. The neutron and gamma attenuation were calculated again.

Radiation in the concrete will heat the concrete. The heating that would be expected for a typical plant was also calculated and compared to acceptable temperatures for concrete.

These calculations were performed for typical PWRs. The neutron fluence levels in the concrete of BWRs are approximately 7 times lower than in PWRs and is not limiting. In general, the attenuation calculated in the concrete of BWRs would be expected to be similar to that calculated in PWRs.

\subsection{Analytical Model}

Simplified models for both 2-loop and 3-loop pressurized water reactors were developed in MCNP5 [11]. The model is an infinite 2-D cylinder with a point source at the center with a typical U-235 fission spectrum. The center of the core is voided except for a $5 \mathrm{~cm}$ ( 2 inch) thick steel vessel representing the baffle and core barrel followed by $10 \mathrm{~cm}$ of water ( $3.9 \mathrm{inch}$ ) at the edge of the RPV. A $15 \mathrm{~cm}$ (5.9 inch) air gap is modeled between the RPV and a 4 feet thick section of concrete. Photon simulations were performed accounting only for neutron induced photons produced in the RPV and beyond. Sensitivity studies determined that fission produced photons account for less than $10 \%$ of photons reaching the concrete and were thus neglected to simplify the analysis. These simplified models were developed to get an approximate neutron and photon spectrum at the concrete interface.

The MCNP5 model uses ENDF/BVII.0 continuous energy nuclear data at 300K with full scattering order representation. A cutoff on energy was applied below $0.01 \mathrm{MeV}$ on the neutron-only simulations to reduce simulation time. 


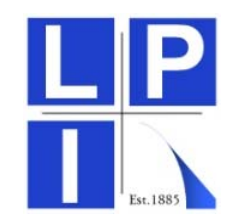

Additionally, geometric weight windows were used at the concrete interface to reduce variance in the flux tallies. Sensitivity studies were performed on data temperature and water thickness inside the RPV, both of which show little variation in results. The results were compared with the ORNL [6] and TransWare [5] results in the RPV for flux ratios between $>1.0 \mathrm{MeV}$ and $>0.1$ $\mathrm{MeV}$, as well as comparisons of the attenuation coefficient assuming exponential attenuation through the RPV described by Randall [8].

The models were run for Portland concrete as defined in the PNNL report [12]. Natural element compositions no longer defined in ENDF/BVII were unfolded from natural isotopic compositions [13]. Austenitic stainless steel type 304 was selected for the core barrel and carbon steel was selected for the RPV and as defined in the MIT BEAVRS benchmark [14].

Flux tallies are performed in the RPV in the first $0.25 \mathrm{~cm}(0.1 \mathrm{inch})$ at $0 T$ and the last $0.25 \mathrm{~cm}$ at $1 \mathrm{~T}$ RPV locations. Tallies are also performed in the concrete in the first $0.25 \mathrm{~cm}$, followed by $2 \mathrm{~cm}(0.79$ inch) increments up to 2 feet and $5 \mathrm{~cm}$ (2.0 inch) increments up to 4 feet. All neutron-only simulations were performed using 100 million source neutrons and secondary photon calculations were performed using 10 million source neutrons with no neutron energy cutoff. All results are normalized per source neutrons.

The goal of this simulation was not to determine the fluence in the RPV and concrete, but rather to determine how the fluence is attenuated through the concrete. Actual fluence data will be taken from plant reported information and scaled appropriately. All MCNP5 uncertainties in the RPV were below $0.1 \%$ and results are reported in concrete until a statistical error of $\sim 1 \%$ is reached.

The MCNP model was modified by adding layers of concrete and layers of a homogenous mixture of steel and concrete. The cavity design for a 4 loop PWR is shown in Figure 4-1. The rebar was modeled as carbon steel with properties taken from the PNNL [12] report from which the concrete composition was also taken. Table 4-1 presents the concrete layers used in the model. Additional layers were modeled up to 72 inches. The rebar was incorporated into the model with the Portland concrete. 


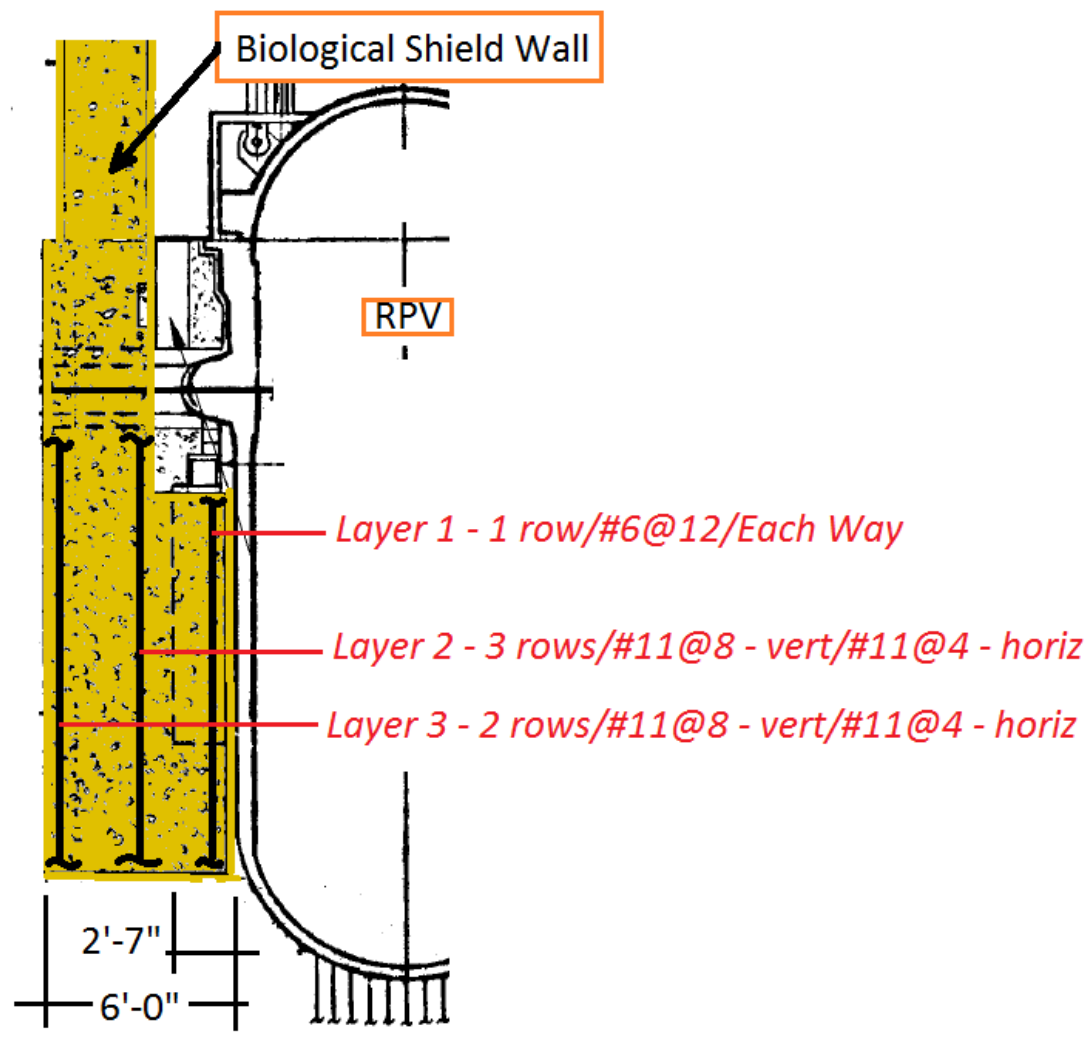

Figure 4-1: Shield Wall Reinforcing at a Sample 4-loop PWR

Table 4-1: Concrete Layers Composition for Sample PWR

\begin{tabular}{|c|c|}
\hline Layer (in inches) & Composition (by volume) \\
\hline 0 to 2.625 & concrete \\
\hline 2.625 to 3.375 & $7: 1$ concrete to steel \\
\hline 3.375 to 32.3125 & concrete \\
\hline 32.3125 to 33.6875 & $1: 1$ concrete to steel \\
\hline 33.6875 to 37.3125 & concrete \\
\hline
\end{tabular}




\subsection{Neutron Results}

\subsubsection{Two-Loop PWR}

The 2-loop model used a RPV inner diameter of 3.352 meters (132 inches) and a wall thickness of $165 \mathrm{~mm}$ (6.5 inches).

Comparisons in the RPV calculations were made with the ORNL 2-loop model [6] that has a similar vessel thickness. Table 4-2 and 4-3 show similar trends in the ratio of flux $>0.1 \mathrm{MeV}$ to $>1.0 \mathrm{MeV}$ at $0 \mathrm{~T}$, however the attenuations are slightly different, which is to be expected when comparing a continuous energy model with exact scattering distributions and a deterministic model with a finite number of energy group with limited scattering expansion. The variation between models is considered small enough such that the MCNP5 model can provide a reasonable spectrum for evaluation of attenuation in the concrete. Additionally, the RPV thickness of the ORNL 2-loop plant is slightly larger than that reported for the 2-loop plant used for this study. It should also be noted that the exponent column corresponds to the natural log of the flux at 1T divided by the flux at 0T divided by the thickness in inches. This is done to back-calculate the attenuation coefficient for comparison with the one provided by Randall [8] of -0.33 for energies $>1.0 \mathrm{MeV}$.

Table 4-5 shows the flux for various distances into the concrete shield wall. This data is used to plot the attenuation which is shown in Figure 4-2.

Table 4-2: MCNP5 Neutron Flux Results for 2-Loop Model (n/cm²s normalized per source neutron)

\begin{tabular}{|l|c|c|c|c|}
\hline \multicolumn{1}{|c|}{ Term } & 0T & 1T & Ratio 1T/0T & Exponent \\
\hline$>1 \mathrm{MeV}$ & $1.02 \times 10^{-5}$ & $1.14 \times 10^{-6}$ & 0.113 & -0.33 \\
\hline$>0.1 \mathrm{MeV}$ & $2.88 \times 10^{-5}$ & $9.19 \times 10^{-6}$ & 0.319 & -0.18 \\
\hline Ratio $>0.1 />1$ & 2.86 & 8.04 & & \\
\hline
\end{tabular}


Table 4-3: ORNL Neutron Flux Results for 2-Loop Model (n/cm²s) [6]

\begin{tabular}{|l|c|c|c|c|}
\hline & 0T & 1T & Ratio 1T/0T & Exponent \\
\hline$>1 \mathrm{MeV}$ & $3.60 \times 10^{10}$ & $3.58 \times 10^{9}$ & 0.099 & -0.35 \\
\hline$>0.1 \mathrm{MeV}$ & $1.00 \times 10^{11}$ & $3.04 \times 10^{10}$ & 0.304 & -0.18 \\
\hline Ratio $>0.1 />1$ & 2.78 & 8.49 & & \\
\hline
\end{tabular}

Table 4-4: Neutron Flux Attenuation $\left(\mathrm{n} / \mathrm{cm}^{2} \mathrm{~s}-\right.$ normalized per source neutron) with Distance for 2 Loop Plant

\begin{tabular}{|c|c|c|}
\hline Distance (cm) & $\begin{array}{c}\text { Distance } \\
\text { (inches) }\end{array}$ & Flux (>0.1 MeV) \\
\hline 0.125 & 0.049 & $8.30 \mathrm{E}-6$ \\
\hline 1.125 & 0.443 & $6.81 \mathrm{E}-6$ \\
\hline 3 & 1.181 & $4.68 \mathrm{E}-6$ \\
\hline 5 & 1.969 & $3.16 \mathrm{E}-6$ \\
\hline 7 & 2.756 & $2.17 \mathrm{E}-6$ \\
\hline 9 & 3.543 & $1.50 \mathrm{E}-6$ \\
\hline 11 & 4.331 & $1.04 \mathrm{E}-6$ \\
\hline 13 & 5.118 & $7.38 \mathrm{E}-7$ \\
\hline 15 & 5.906 & $5.27 \mathrm{E}-7$ \\
\hline 17 & 6.693 & $3.80 \mathrm{E}-7$ \\
\hline 19 & 7.480 & $2.76 \mathrm{E}-7$ \\
\hline 21 & 8.268 & $2.04 \mathrm{E}-7$ \\
\hline 23 & 9.055 & $1.52 \mathrm{E}-7$ \\
\hline 25 & 9.843 & $1.14 \mathrm{E}-7$ \\
\hline 27 & 10.630 & $8.64 \mathrm{E}-8$ \\
\hline 29 & 11.417 & $6.60 \mathrm{E}-8$ \\
\hline 31 & 12.205 & $5.09 \mathrm{E}-8$ \\
\hline 33 & 12.992 & $3.95 \mathrm{E}-8$ \\
\hline 36.5 & 14.370 & $2.61 \mathrm{E}-8$ \\
\hline 41.5 & 16.339 & $1.45 \mathrm{E}-8$ \\
\hline 46.5 & 18.307 & $8.35 \mathrm{E}-9$ \\
\hline 51.5 & 20.276 & $4.84 \mathrm{E}-9$ \\
\hline & &
\end{tabular}



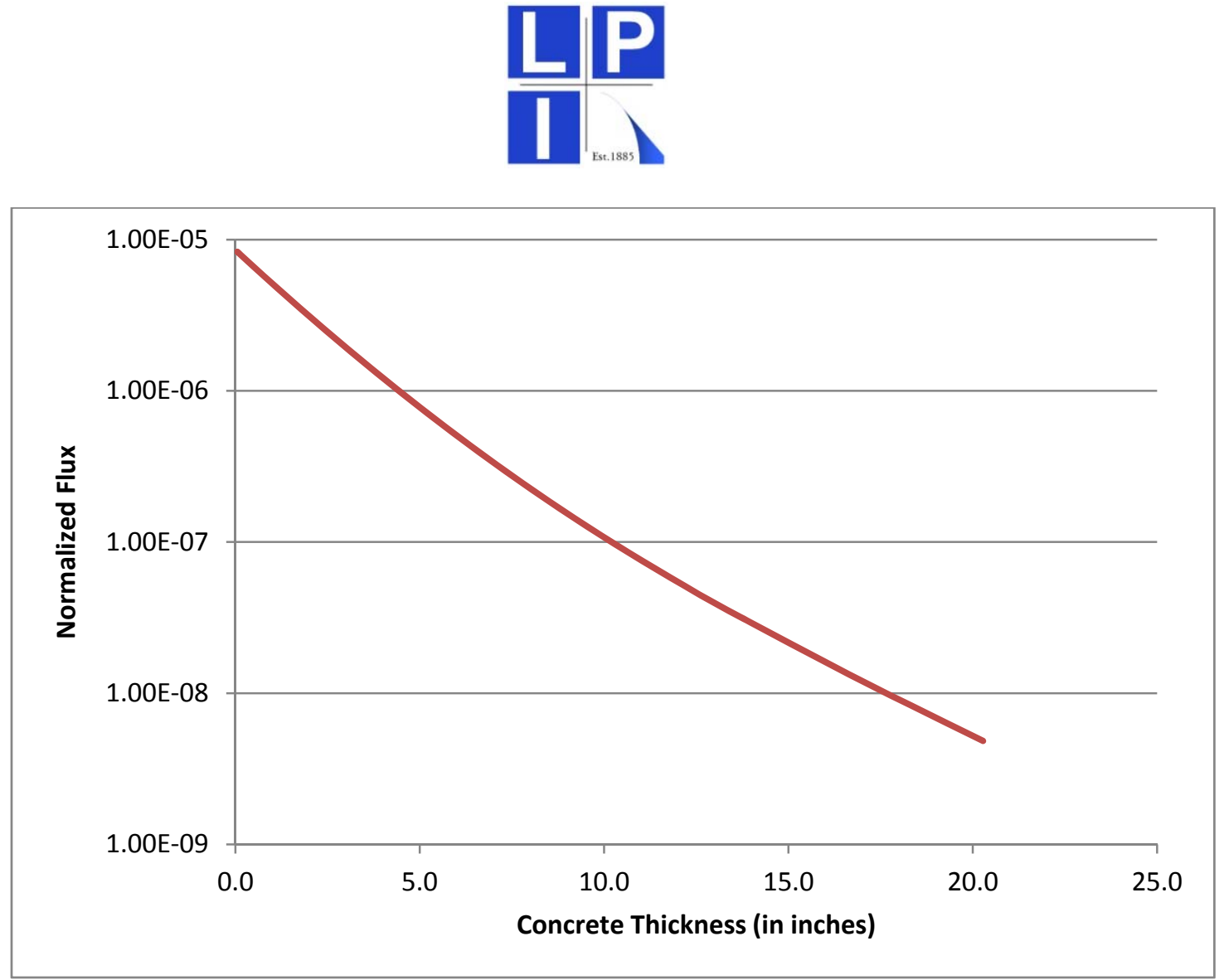

Figure 4-2: Neutron Flux (n/cm ${ }^{2} \mathrm{~s}$ - normalized per source neutron) attenuation in Portland concrete (2-loop model)

\subsubsection{Three-Loop PWR}

The three loop simplified model used a RPV inner diameter of 3.95 meters (155.5 inches) and a wall thickness of $237 \mathrm{~mm}$ (9.3 inches).

Comparisons in the RPV calculations were made with both ORNL and TransWare [5] results for the same plant. Table 4-6, 4-7, and 4-8 present these results. All three models agree quite well in terms of ratios and fluence attenuation exponents.

Table 4-9 shows the flux for various distances into the concrete shield wall. This data is used to plot the attenuation which is shown in Figure 4-3. 
Table 4-5: MCNP5 Neutron Flux Results for 3-loop model (n/cm² $\mathbf{s}-$ normalized per source neutron)

\begin{tabular}{|l|c|c|c|c|}
\hline & 0T & 1T & Ratio 1T/0T & Exponent \\
\hline$>1 \mathrm{MeV}$ & $8.54 \times 10^{-6}$ & $4.08 \times 10^{-7}$ & 0.0477 & -0.32 \\
\hline$>0.1 \mathrm{MeV}$ & $2.50 \times 10^{-5}$ & $5.92 \times 10^{-6}$ & 0.237 & -0.15 \\
\hline Ratio $>0.1 />1$ & 2.93 & 14.5 & & \\
\hline
\end{tabular}

Table 4-6: ORNL Neutron Flux Results for 3-loop plant model (n/cm²) [6]

\begin{tabular}{|l|c|c|c|c|}
\hline & 0T & 1T & Ratio 1T/0T & Exponent \\
\hline$>1 \mathrm{MeV}$ & $2.50 \times 10^{10}$ & $1.04 \times 10^{9}$ & 0.0416 & -0.33 \\
\hline$>0.1 \mathrm{MeV}$ & $6.50 \times 10^{10}$ & $1.43 \times 10^{10}$ & 0.220 & -0.16 \\
\hline Ratio $>0.1 />1$ & 2.60 & 13.8 & & \\
\hline
\end{tabular}

Table 4-7: TwE Neutron Flux Results for 3-loop plant model (n/cm $\left.{ }^{2} \mathrm{~s}\right)$ [5]

\begin{tabular}{|l|c|c|c|c|}
\hline & 0T & $\mathbf{1 T}$ & Ratio 1T/0T & Exponent \\
\hline$>1 \mathrm{MeV}$ & $3.46 \times 10^{10}$ & $1.31 \times 10^{9}$ & 0.0379 & -0.34 \\
\hline$>0.1 \mathrm{MeV}$ & $1.01 \times 10^{11}$ & $1.77 \times 10^{10}$ & 0.175 & -0.18 \\
\hline Ratio $>0.1 />1$ & 2.92 & 13.5 & & \\
\hline
\end{tabular}


Table 4-8: Neutron Flux (n/cm² ${ }^{2}$ - normalized per source neutron) attenuation in Portland concrete (3-loop)

\begin{tabular}{|c|c|c|}
\hline Distance $(\mathrm{cm})$ & Distance (inches) & Flux $(>0.1 \mathrm{MeV})$ \\
\hline 0.125 & 0.049 & $5.10 \times 10^{-6}$ \\
\hline 1.125 & 0.443 & $4.09 \times 10^{-6}$ \\
\hline 3 & 1.181 & $2.69 \times 10^{-6}$ \\
\hline 5 & 1.969 & $1.74 \times 10^{-6}$ \\
\hline 7 & 2.756 & $1.13 \times 10^{-6}$ \\
\hline 9 & 3.543 & $7.48 \times 10^{-7}$ \\
\hline 11 & 4.331 & $4.98 \times 10^{-7}$ \\
\hline 13 & 5.118 & $3.35 \times 10^{-7}$ \\
\hline 15 & 5.906 & $2.27 \times 10^{-7}$ \\
\hline 17 & 6.693 & $1.56 \times 10^{-7}$ \\
\hline 19 & 7.480 & $1.08 \times 10^{-7}$ \\
\hline 21 & 8.268 & $7.58 \times 10^{-8}$ \\
\hline 23 & 9.055 & $5.37 \times 10^{-8}$ \\
\hline 25 & 9.843 & $3.85 \times 10^{-8}$ \\
\hline 27 & 10.630 & $2.81 \times 10^{-8}$ \\
\hline 29 & 11.417 & $2.07 \times 10^{-8}$ \\
\hline 31 & 12.205 & $1.54 \times 10^{-8}$ \\
\hline 33 & 12.992 & $1.17 \times 10^{-8}$ \\
\hline 36.5 & 14.370 & $7.38 \times 10^{-9}$ \\
\hline 41.5 & 16.339 & $3.87 \times 10^{-9}$ \\
\hline
\end{tabular}




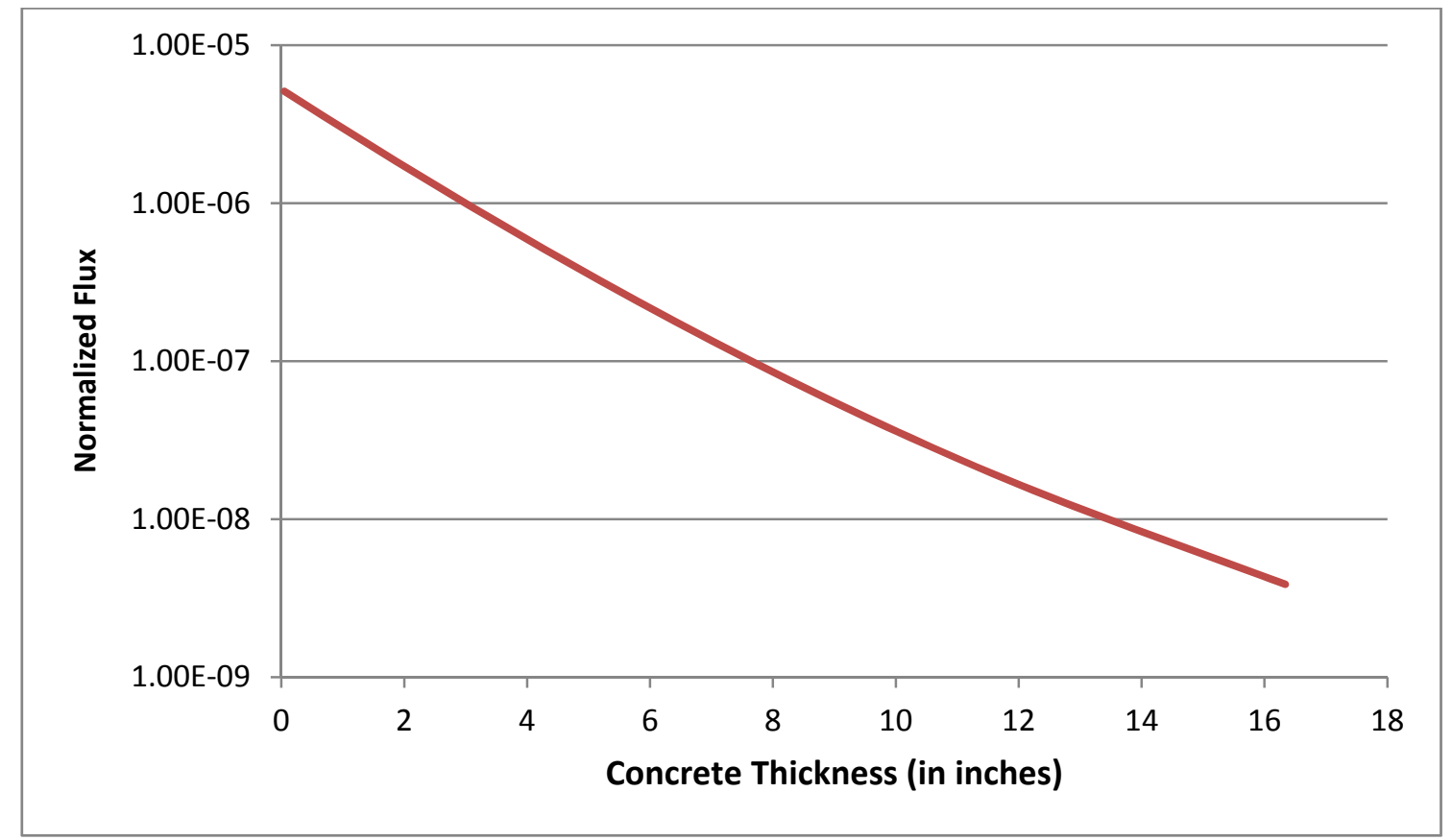

Figure 4-3: Neutron Flux (n/cm ${ }^{2} \mathrm{~s}$ - normalized per source neutron) attenuation in Portland concrete ( 3 loop model) $(E>0.1 \mathrm{MeV})$

\subsubsection{Rate of Neutron Attenuation}

The Portland concrete neutron flux data for the two loop and the three loop plant was normalized to the flux at zero inches (actually, the initial depth is 0.049 inches). The ratio of the flux at a depth to the flux at zero is the rate of attenuation of the neutron flux.

That data is shown in Figure 4-4. Note that the flux is reduced by one order of magnitude in approximately 5 inches. The rate of attenuation within this first 5 inches of the concrete is important. The rate of attenuation in this distance has been replotted on a linear scale so that the rate can be more easily discerned. This data is plotted in Figure 4-5. The neutron flux is reduced by half in approximately the first $1 \frac{1}{2}$ inches of concrete. 

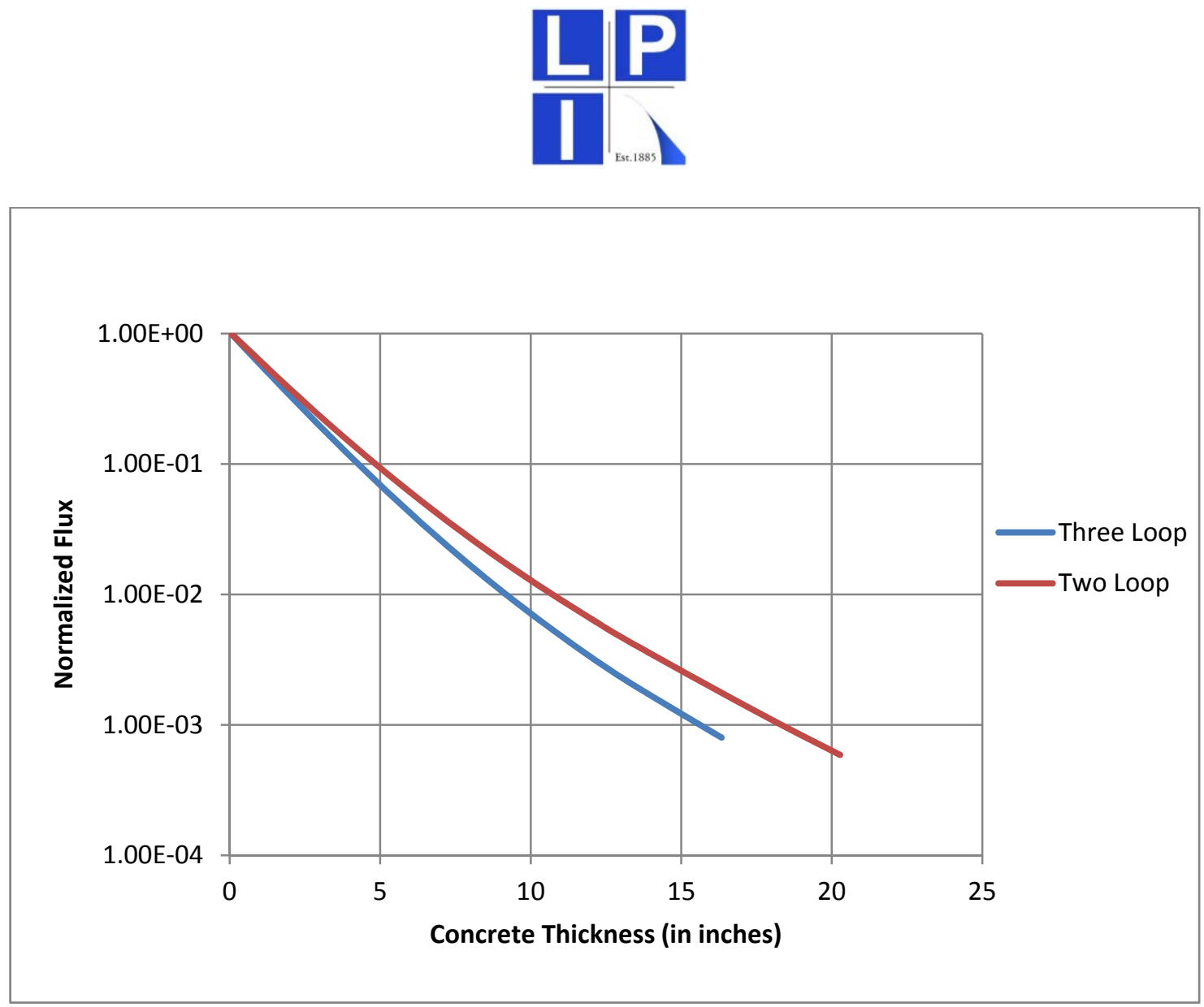

Figure 4-4: Rate of Flux attenuation in Portland concrete for 2-loop and 3 loop model $(E>0.1 \mathrm{MeV})$. 


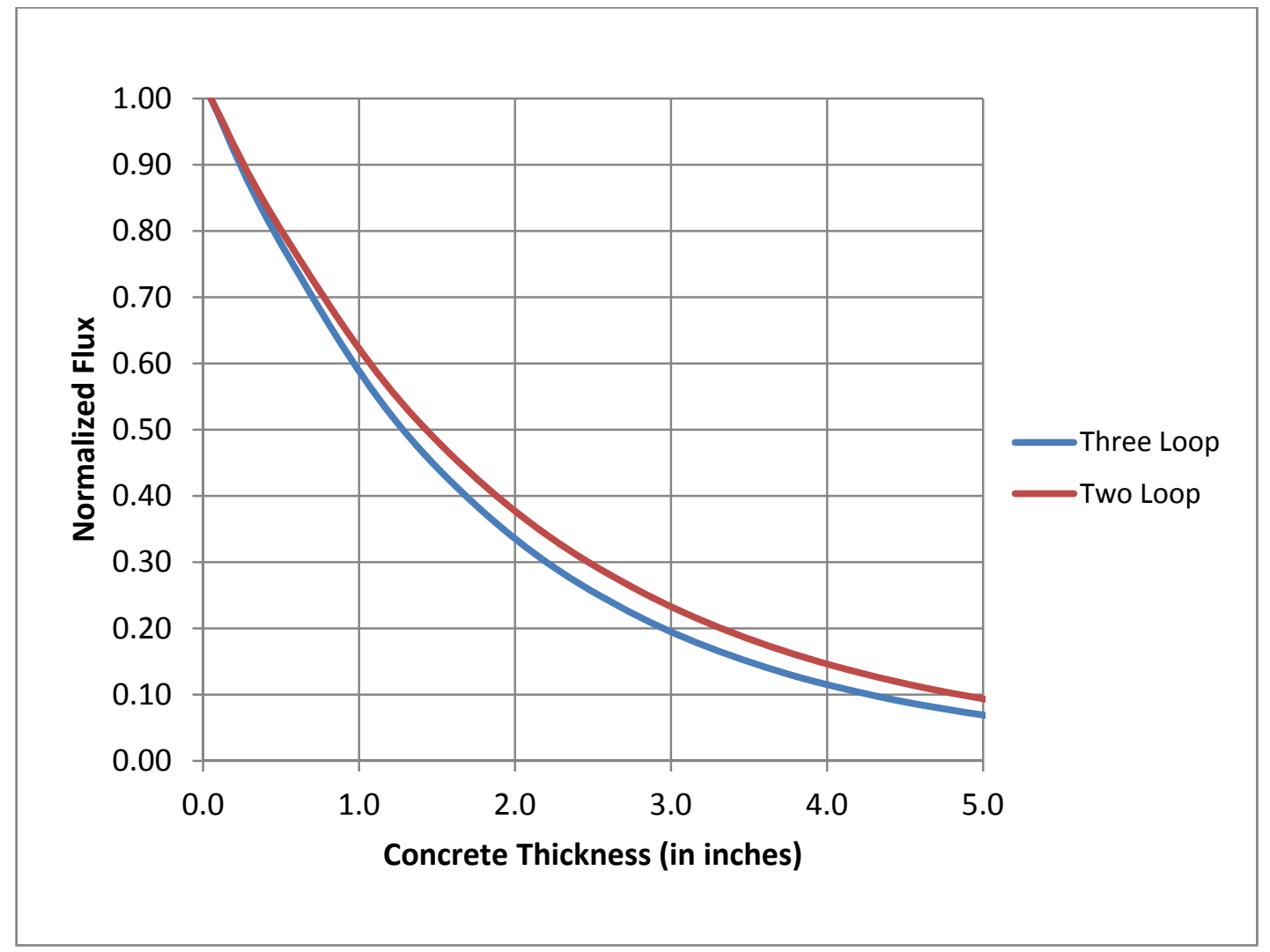

Figure 4-5: Rate of Flux attenuation in Portland concrete for 2-loop and 3 loop model in first 5 inches of concrete $(E>0.1 \mathrm{MeV})$

\subsubsection{Two and Three-Loop PWR Results with Rebar}

Once the model was modified to include rebar, the neutron models were rerun. Figure 4-6 presents the original results for the two loop plant and the added line with rebar. The approximate position of the rebar is indicated with the shaded blue boxes. The blue line (with rebar) was extended to the edge of the second rebar layer (approximately 34 inches). The rebar has a minimal impact on the neutron flux in the reactor shield wall.

The analyses were also run for the 3 loop plant. Those results are presented in Figure 4-7. The rebar can also be seen to have very little impact on the neutron flux. 

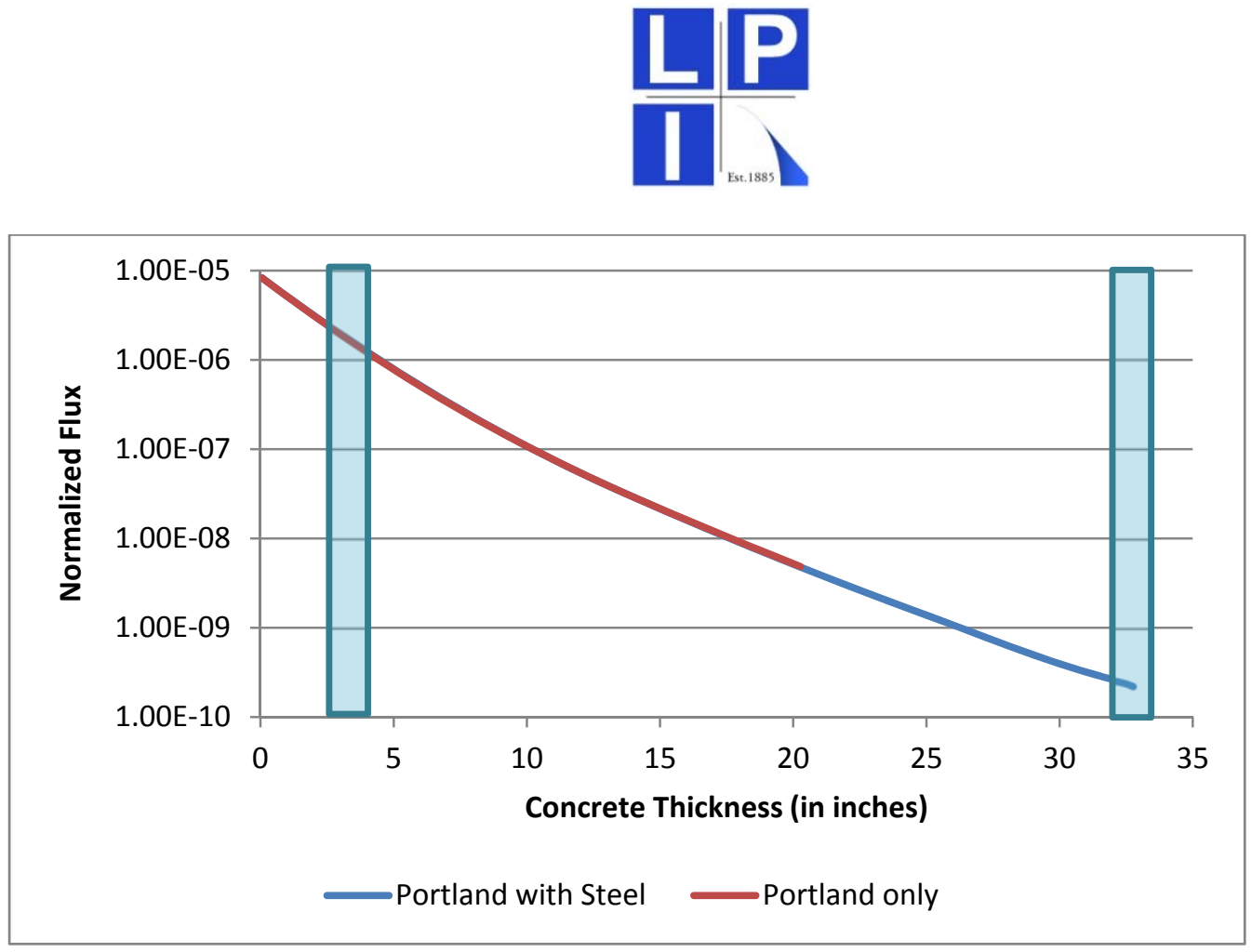

Figure 4-6. Two Loop Plant Neutron Flux Results with and without Rebar (n/cm ${ }^{2}$ s for E > $0.1 \mathrm{MeV}$ - normalized per source neutron) - approximate position of rebar shown in blue boxes.

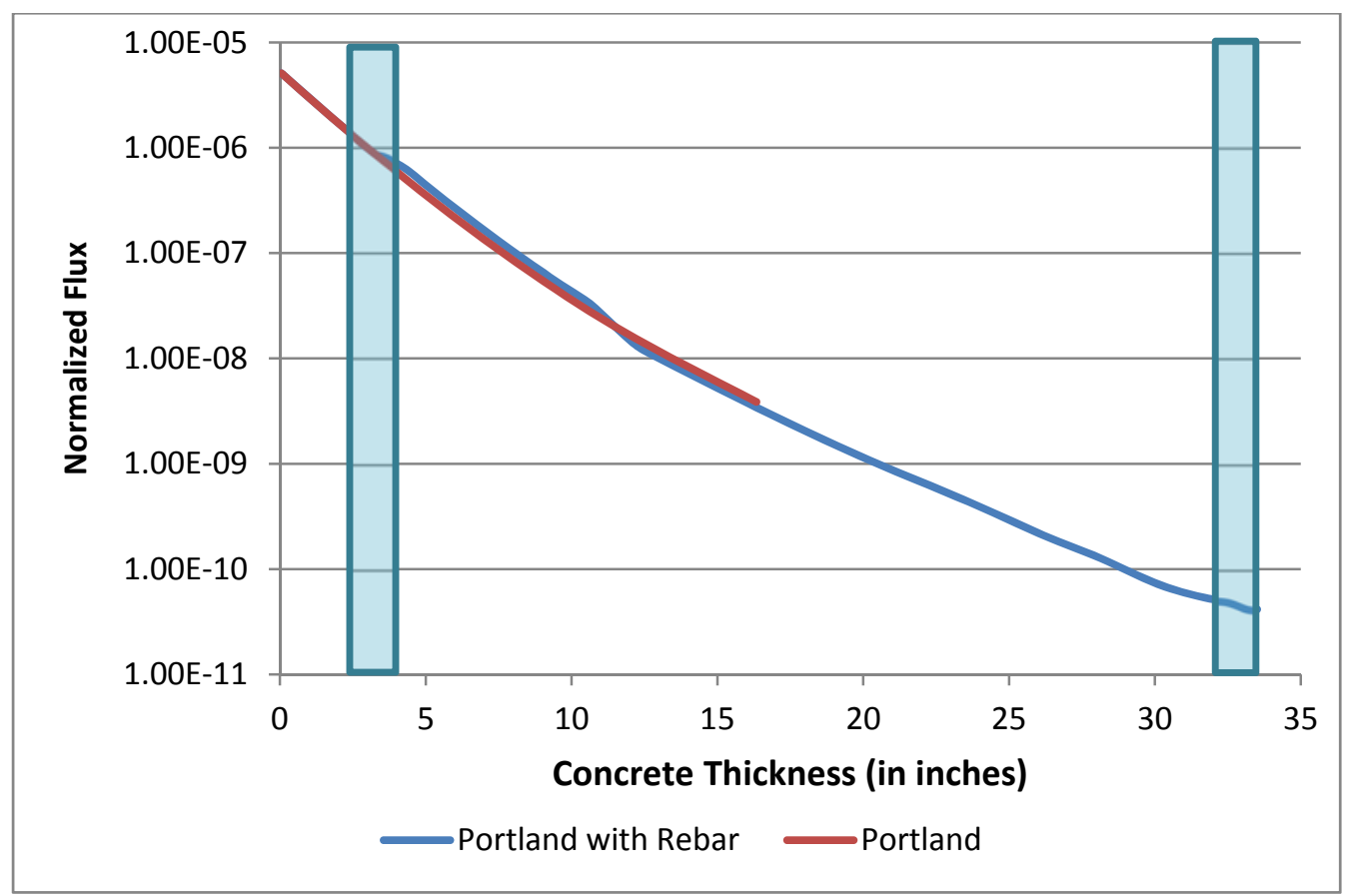

Figure 4-7. Three Loop Plant Results with and without Rebar $\left(\mathrm{n} / \mathrm{cm}^{2} \mathrm{~s}\right.$ for E > $0.1 \mathrm{MeV}$ - normalized per source neutron) - approximate position of rebar shown in blue boxes. 


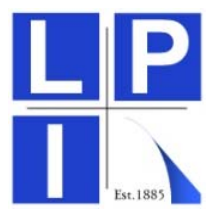

\subsubsection{Gamma Attenuation - Photon Dose}

To evaluate photon dose in concrete, the following formula was used:

$$
\text { DoseRate }=\frac{\mu_{e n}}{\rho} \times I \times E
$$

Where the first term $\left(\mu_{e n} / \rho\right)$ is the known mass energy absorption coefficient where $\mu_{e n}$ is the energy attenuation coefficient, $\rho$ is the material density, $I$ is the photon flux, and $E$ is the energy of the photon. The two last terms can be tallied simultaneously in the MCNP code, thus yielding an energy multiplied flux accounting for the exact photon energy. The first term is taken from the NIST database [15]. The mass energy absorption coefficient curve that is provided by NIST is reproduced in Figure 4-8. The dotted line is the mass energy absorption coefficient. This is stated to be for "ordinary concrete" and is presumed to be valid for Portland concrete.

The analysis model for photon attenuation in concrete is very similar to the ones for neutrons. Reactor vessel insulation comprised of $3 \%$ steel and $97 \%$ air was added in the model but did not have any significant effect on the results. The photon model neglects photons produced by fission and by absorption inside the core. Only photons produced by neutron capture in the RPV and beyond are considered. A sensitivity study was performed with varying energy photons to determine if fission photons could make it out of the RPV. It was determined that the contribution from fission neutrons was an order of magnitude less than that from secondary photons (neutron-induced) in the RPV. As a result, the fission photons were neglected and the analysis was simplified. The photons produced in the approximate core barrel and water gap were also neglected since their contribution is minimal and the simplified model cannot account for them accurately. Thus it should be noted that the simplified model used here will slightly underestimate the photon flux, but will provide an adequate basis to determine the attenuation in the concrete. The photon flux given by MCNP is normalized per source neutron. A scaled value was determined by comparing the neutron attenuation results from the previous analysis and ORNL values at $1 \mathrm{~T}$ [6]. 
This method is approximate and is not appropriate to accurately calculate the photons for a particular plant. They do not coincide accurately with plant predictions, but that was not the intent. These models were prepared to determine the attenuation in the concrete.

The two loop plant was analyzed. The attenuation in the concrete for the three loop plant will be similar.

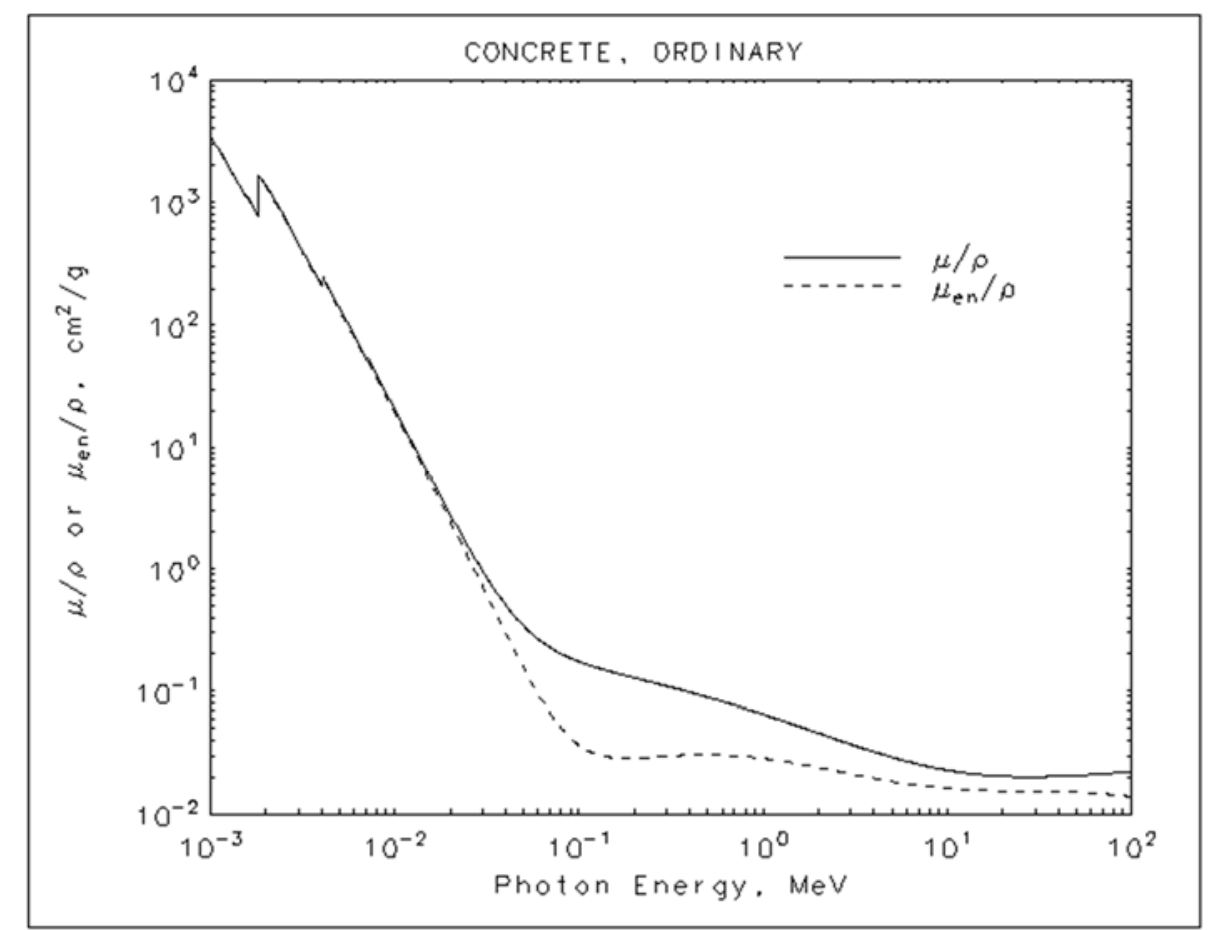

Figure 4-8: Mass energy attenuation coefficient (from NIST) [15]

A. Two Loop Results - Concrete Only

Tallies were added in the RPV and concrete structure to get the energy multiplied flux. The energy structure was separated in many bins in which the mass energy absorption coefficient can be assumed constant. Preliminary analysis indicated that the dose for energies below $0.05 \mathrm{MeV}$ were many orders of magnitude less than at higher energies, so only 4 energy bins were followed with mass energy absorption coefficient indicated below. 


$\begin{array}{ll}\text { Group 1: } 10-20 \mathrm{MeV} & 0.0156 \mathrm{~cm}^{2} / \mathrm{g} \\ \text { Group 2: } 1-10 \mathrm{MeV} & 0.0185 \mathrm{~cm}^{2} / \mathrm{g} \\ \text { Group 3: } 0.1-1 \mathrm{MeV} & 0.03 \mathrm{~cm}^{2} / \mathrm{g} \\ \text { Group 4: } 0.05-0.1 \mathrm{MeV} & 0.065 \mathrm{~cm}^{2} / \mathrm{g}\end{array}$

Figure 4-9 presents the photon flux in just Portland concrete. Figure 410 presents the dose rates at a few locations in the concrete.

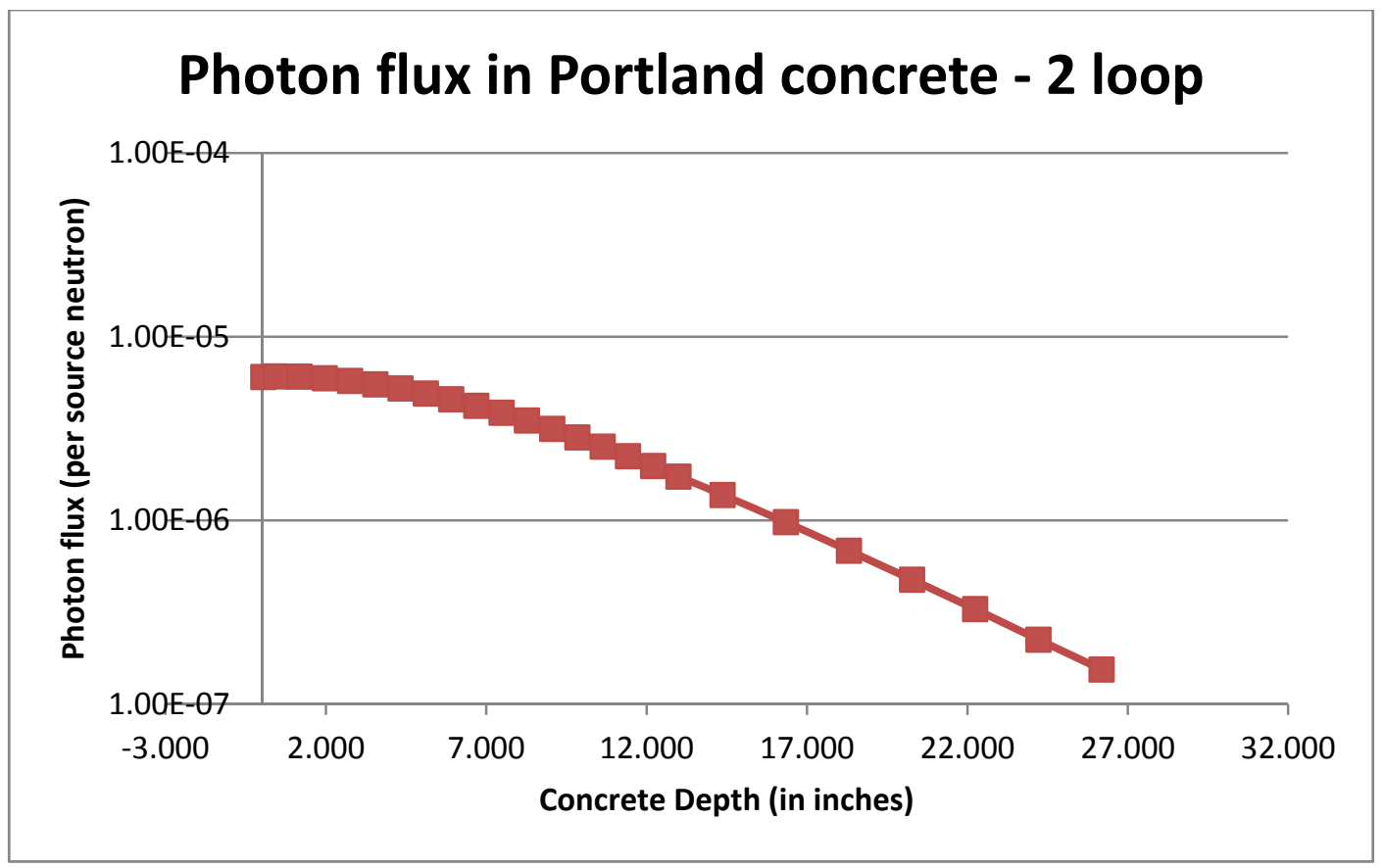

Figure 4-9: Photon Flux ( $\mathrm{n} / \mathrm{cm}^{2}$ s normalized per source neutron) in Portland Concrete - Two Loop Plant 

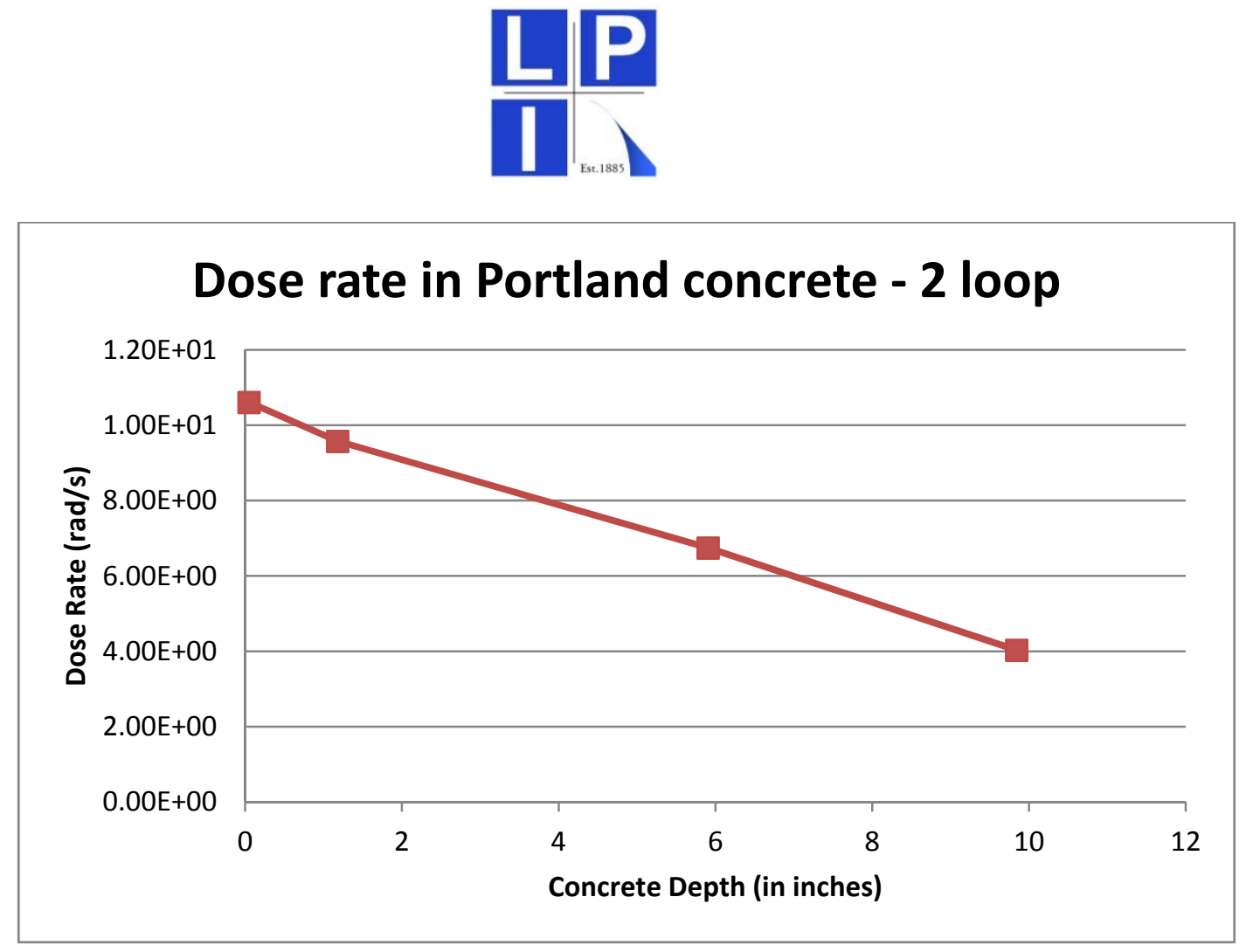

Figure 4-10: Dose Rate (rad/sec) in Portland Concrete (normalized using neutron flux at 1T from ORNL study) - Two Loop Plant

B. Two Loop Results - Concrete and Rebar

The calculations were repeated with rebar added as was described previously. Figure 4-11 shows the results for photon flux with and without rebar in Portland concrete. Once again the impact is minimal, with the exception of a slight dip in the second rebar layer. The "with rebar" curve was extended beyond the $1 \%$ statistical uncertainty of the results to show the trend.

The absorbed dose rate was averaged over both rebar positions and yielded an average of $10.6 \mathrm{rad} / \mathrm{s}$ in the first layer and $0.05 \mathrm{rad} / \mathrm{s}$ in the second. Figure 4-12 presents the dose rate with and without rebar.

The jump at 3 inches in the Dose Rate curve is due to the presence of the rebar. Neutron collisions will produce more photons in steel, but the dose rate attenuates substantially afterwards. 


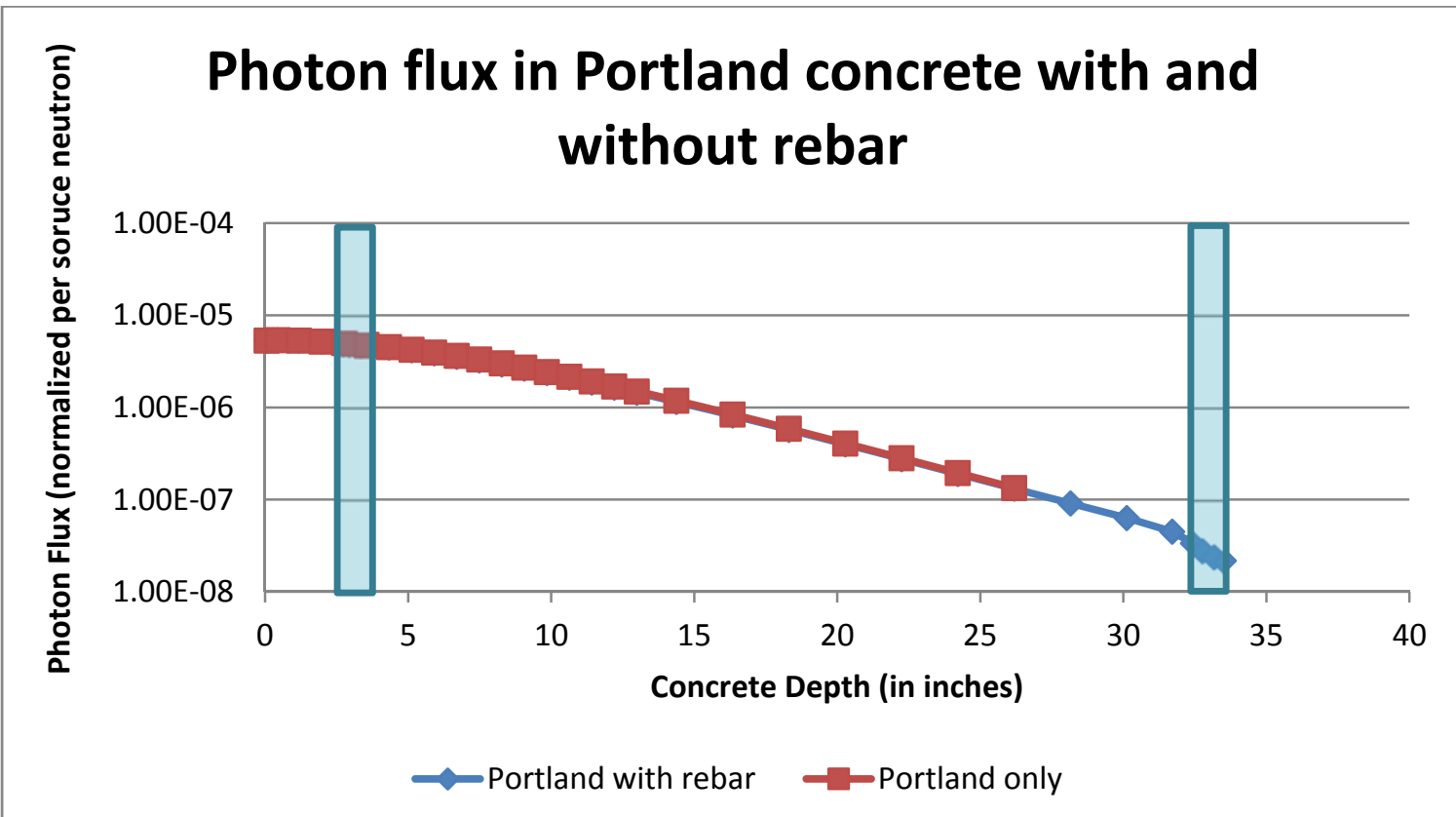

Figure 4-11: Photon Flux in Concrete with and without Rebar (normalized per source neutron) - Two Loop Plant - approximate position of rebar shown in blue boxes

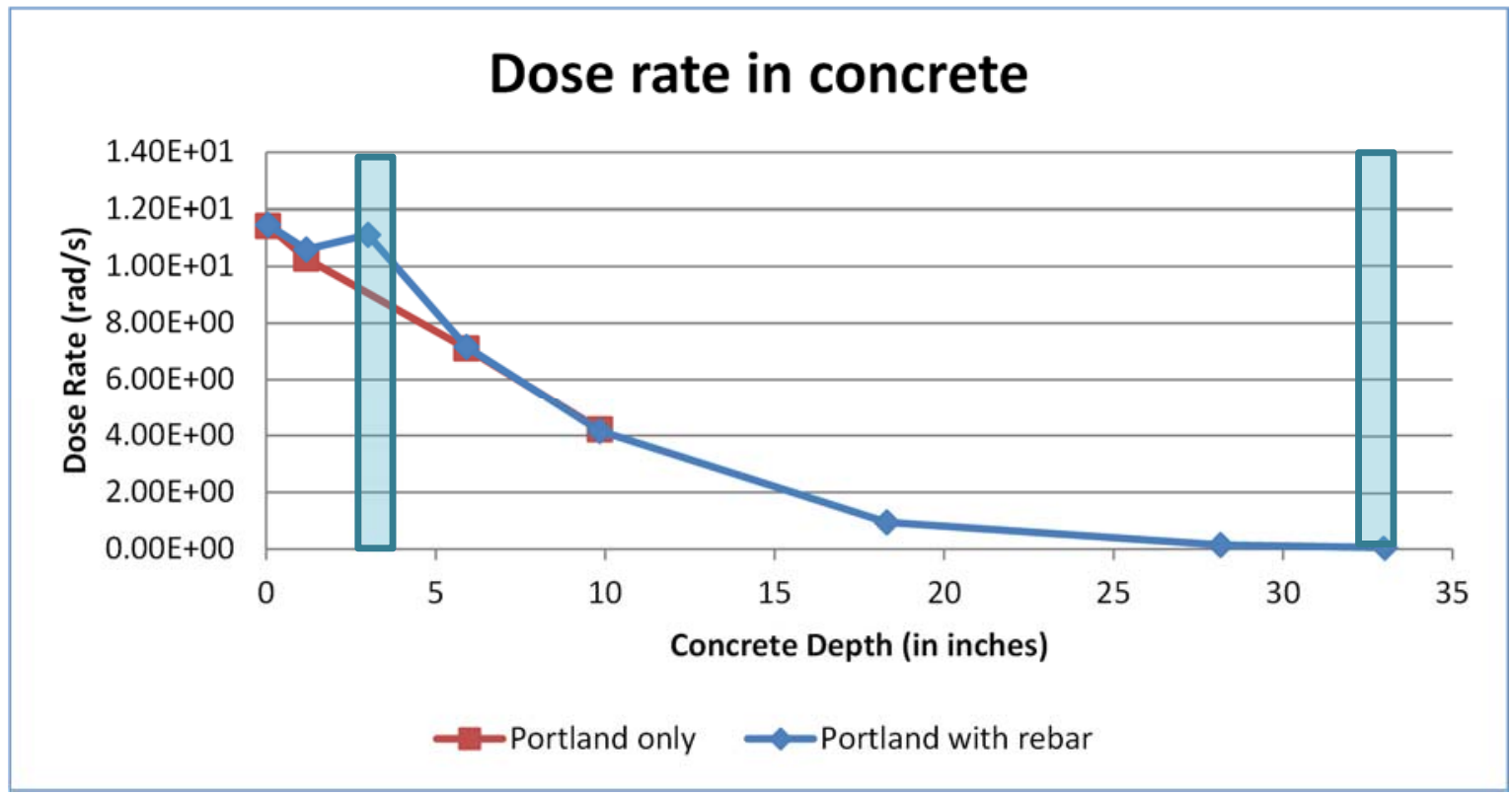

Figure 4-12: Dose Rate (rad/sec) in Concrete with and without Rebar (normalized using neutron flux at 1T from ORNL study) - Two Loop Plant approximate position of rebar shown in blue boxes 


\subsection{Gamma Heating Evaluation}

The thermal heating due to radiation exposure in a biological shield at the peak elevation was evaluated by TwE [5]. The total thermal heating in the biological shield was determined with a finite element analysis. The contributions of the ambient temperatures in the cavity region inside the biological shield and the neutron and gamma radiation energies deposited in the biological shield wall were evaluated.

The temperature of the cavity was presumed to be $150^{\circ} \mathrm{F}$. Many plants circulate containment air through this cavity and it is expected that most plants will operate near or below $150^{\circ} \mathrm{F}$.

With an inner surface wall temperature of $150^{\circ} \mathrm{F}$, the maximum temperature in the shield wall was approximately $159^{\circ} \mathrm{F}$. This was located at a depth of approximately 3.2" into the wall. This included the effect of the ambient temperature on the inside surface of the reactor cavity and the effects of radiation heating

Figure 4-13 provides a profile of the total temperature distribution in the concrete at the peak elevation.

Based on $150^{\circ} \mathrm{F}$ cavity temperature, which is based on forced cooling of the cavity, the cavity concrete temperature is predicted to be below $180^{\circ} \mathrm{F}$. This is within the American Concrete Institute (ACl) codes [16], [17] and is expected to be below all plant FSAR requirements 


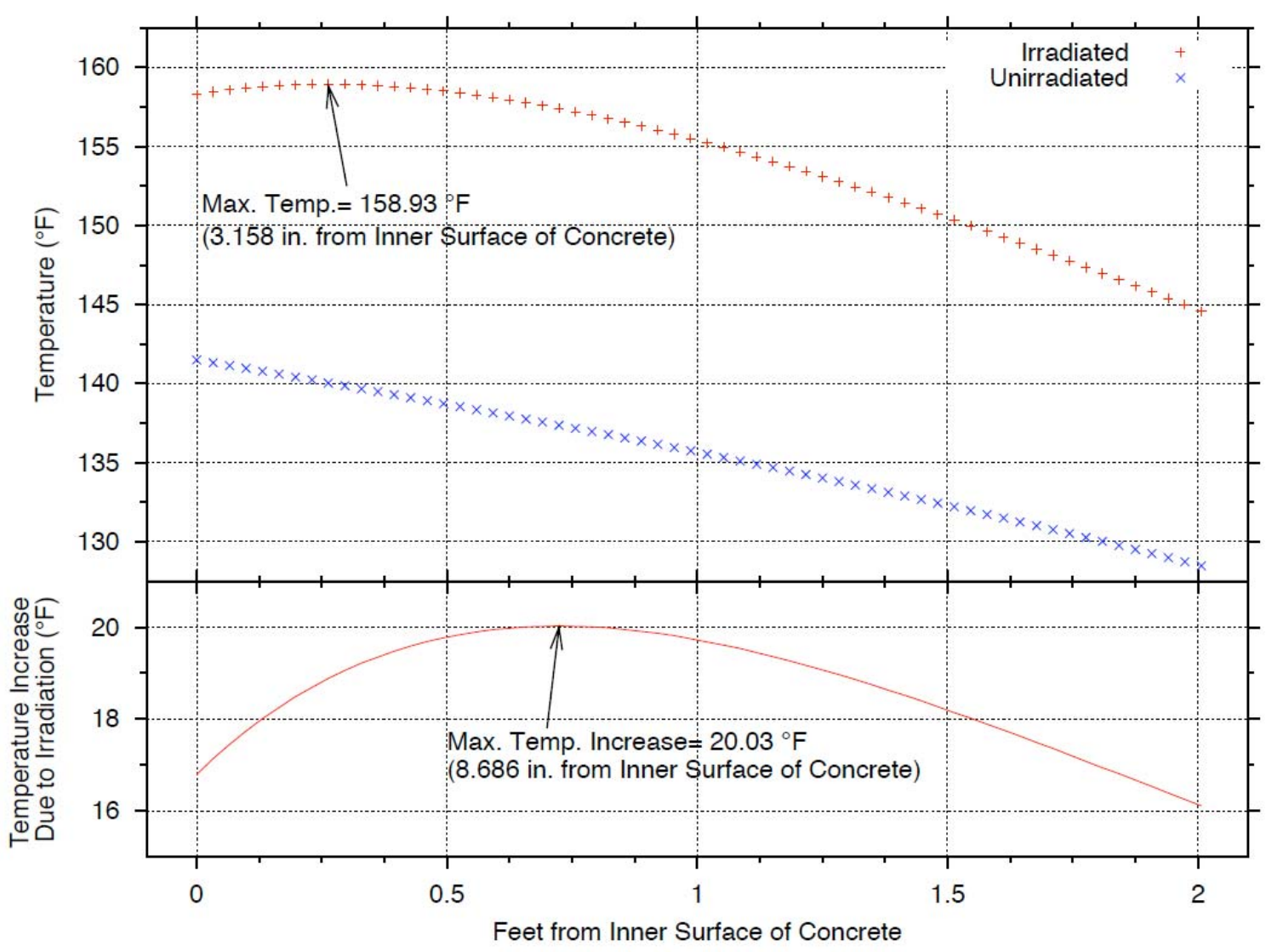

Figure 4-13: Radial Profiles of Temperature Increase in Concrete from Ambient and Radiation Heating [5] 


\section{TEST RESULTS}

In 2012, EPRI performed a literature survey on testing of irradiated concrete [18]. The Technical Paper that has been used by many as the definition of acceptable exposure is a paper by Hilsdorf. In 1978, H. K. Hilsdorf et al. [19] published a paper on the effects of nuclear radiation on the mechanical properties of concrete. The authors compiled and summarized previously published experimental data on the effect of nuclear radiation on the properties of concrete. Figure 5-1 shows a plot of the data evaluated by Hilsdorf for change in compressive strength versus neutron fluence dose. Figure 5-2 shows the change in compressive strength versus gamma dose.

Based on these plots, Hilsdorf concluded that neutron radiation with a fluence of greater than $1 \times 10^{19} \mathrm{n} / \mathrm{cm}^{2}$ (neutron per square centimeter) may have a detrimental effect on concrete strength and modulus of elasticity [19].

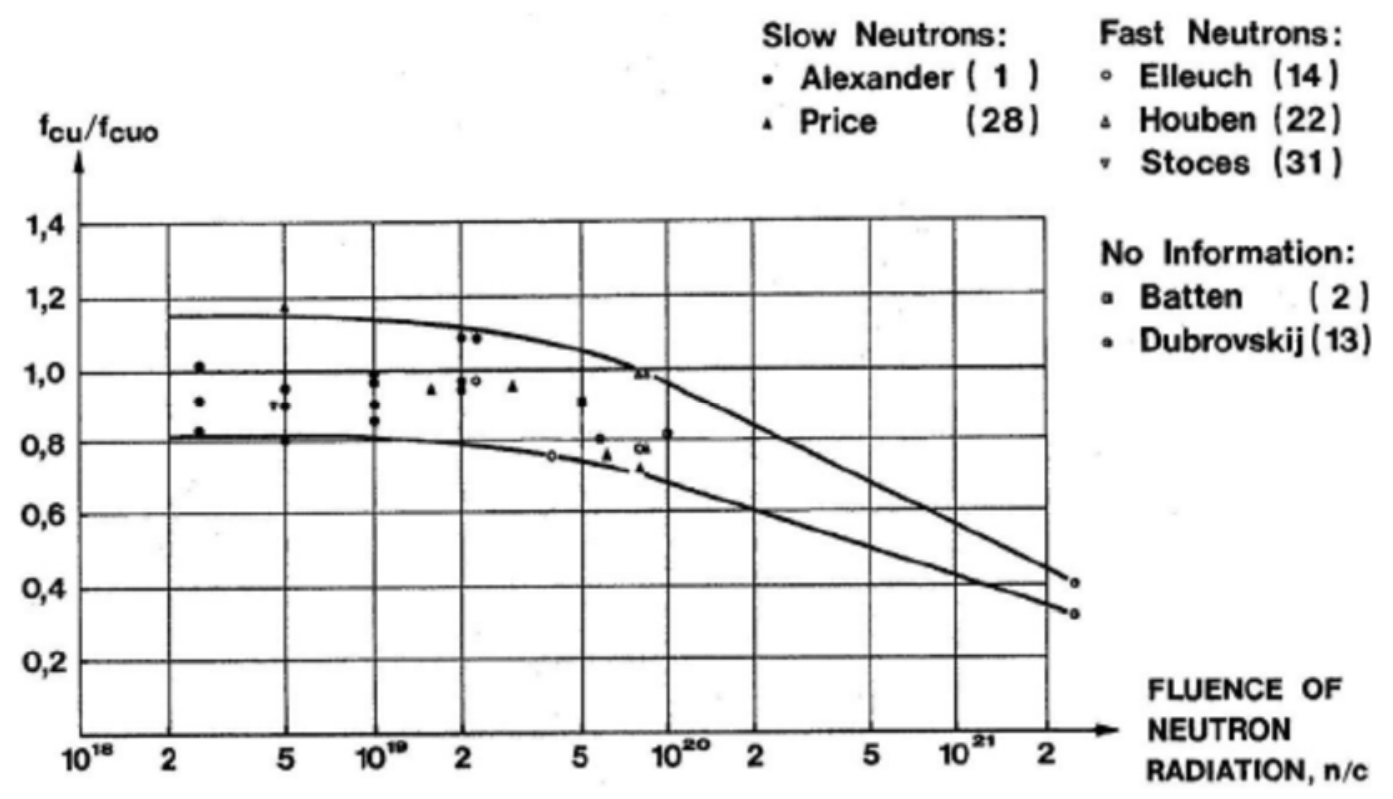

Figure 5-1: Compressive strength of concrete exposed to neutron radiation $f_{c u}$ related to strength of untreated concrete $f_{c u o}$ (Reprinted from [19]) 


\section{LP \\ II.}

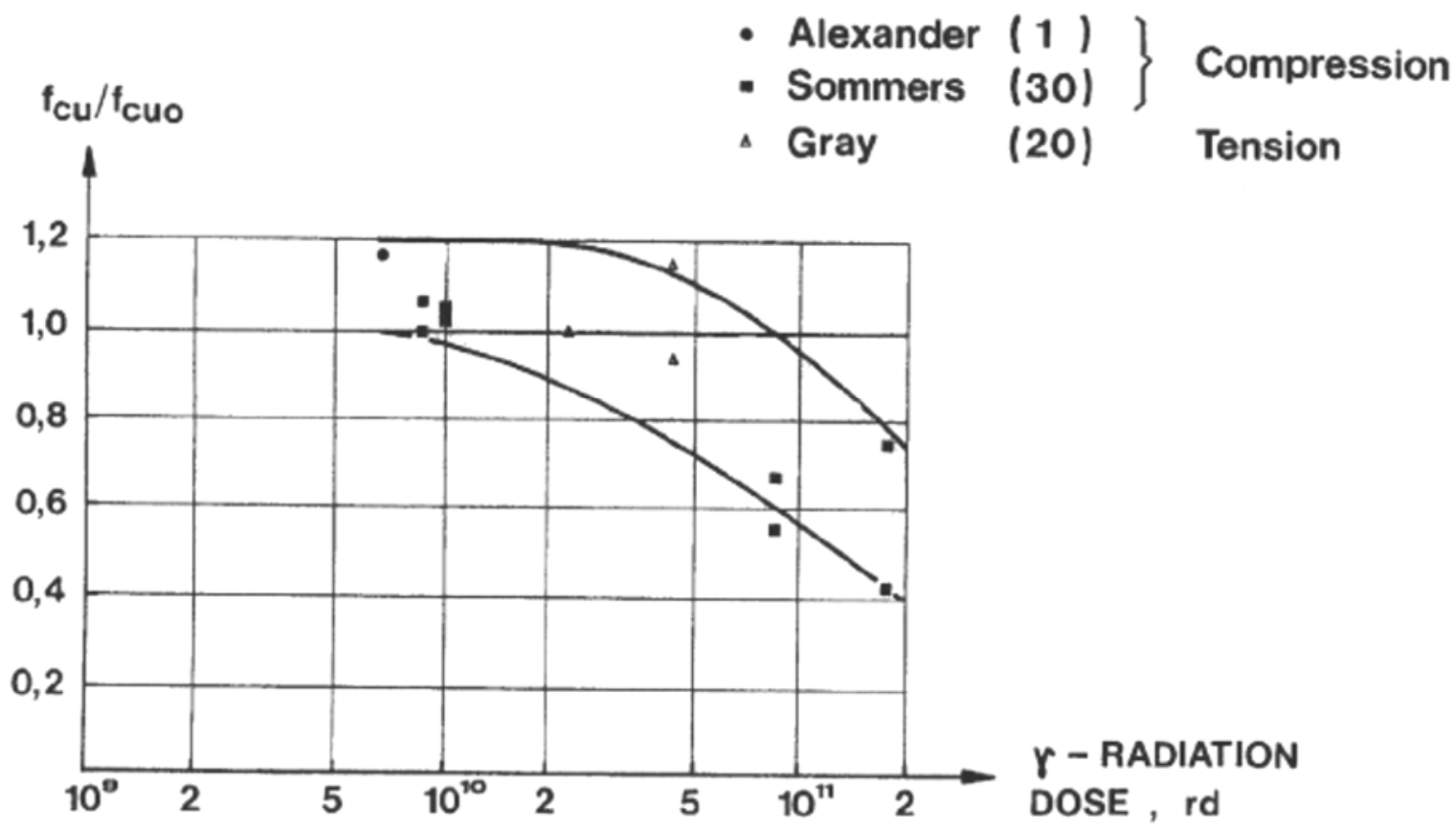

Figure 5-2: Compressive and tensile strength of concrete exposed to gamma radiation $f_{c u}$ related to strength of untreated concrete $f_{c u o}$ (Reprinted from [19])

\subsection{Neutron Testing}

All the testing reported by Hilsdorf was performed during the period from approximately 1963 to 1972 . The technical papers referenced by Hilsdorf, in general, do not provide detail on the energy of the neutrons. Even in Figure 51 here, which is reproduced from the Hilsdorf paper, the data is stated to include both fast neutrons and slow neutrons, and some that are not defined. It is also difficult to reproduce the energy spectra that were used in the testing as details on the test reactors and the specific locations that the tests were placed inside the reactor are often not described. Some of the data presented was from early test reactors that the energy spectra were not reported. Many of the test reactors were not similar to commercial nuclear reactors, and thus may not have energy spectra that would be representative of commercial plants.

Kontani et al [2] concluded in 2010 that the test conditions in which some of the data used in Hilsdorf's neutron data summary are very different from the irradiation and heat conditions usually found in a commercial light water reactor (LWR) power plant. Kontani points out that the concrete containment structures 
in LWRs are typically made from Portland cement and temperatures in the reactor building are normally kept below 65 degrees Celsius $\left(150^{\circ} \mathrm{F}\right)$. In the Hilsdorf paper [19], two data points with fluence greater than $2 \times 10^{21} \mathrm{n} / \mathrm{cm}^{2}$ were obtained from samples made of liquid glass under irradiated temperatures of up to $500^{\circ} \mathrm{C}\left(930^{\circ} \mathrm{F}\right)$. Numerous data points with fluence levels between $3 \times 10^{19}$ $\mathrm{n} / \mathrm{cm}^{2}$ and $1 \times 10^{20} \mathrm{n} / \mathrm{cm}^{2}$ were obtained from aluminous cement samples under irradiated temperatures between $150-200^{\circ} \mathrm{C}\left(300-390^{\circ} \mathrm{F}\right)$ [2]. Kontani highlighted the Hilsdorf neutron fluence curve with this information. This is shown in Figures 5-3. If the data points that were highlighted by Kontani as unrepresentative, were removed, the trend of decreasing strength with increasing fluence (dose) would be much less well defined [2]. Although less well defined, the threshold values defined by Hilsdorf for neutron exposure would still be conservative. Deleting the data that Kontani highlighted as unrepresentative data indicates that the reduction in strength that was apparent with all the data at neutron exposures greater than approximately $2 \mathrm{E}+19 \mathrm{n} / \mathrm{cm}^{2}$ may not occur for concrete and temperatures that are typical of LWRs.

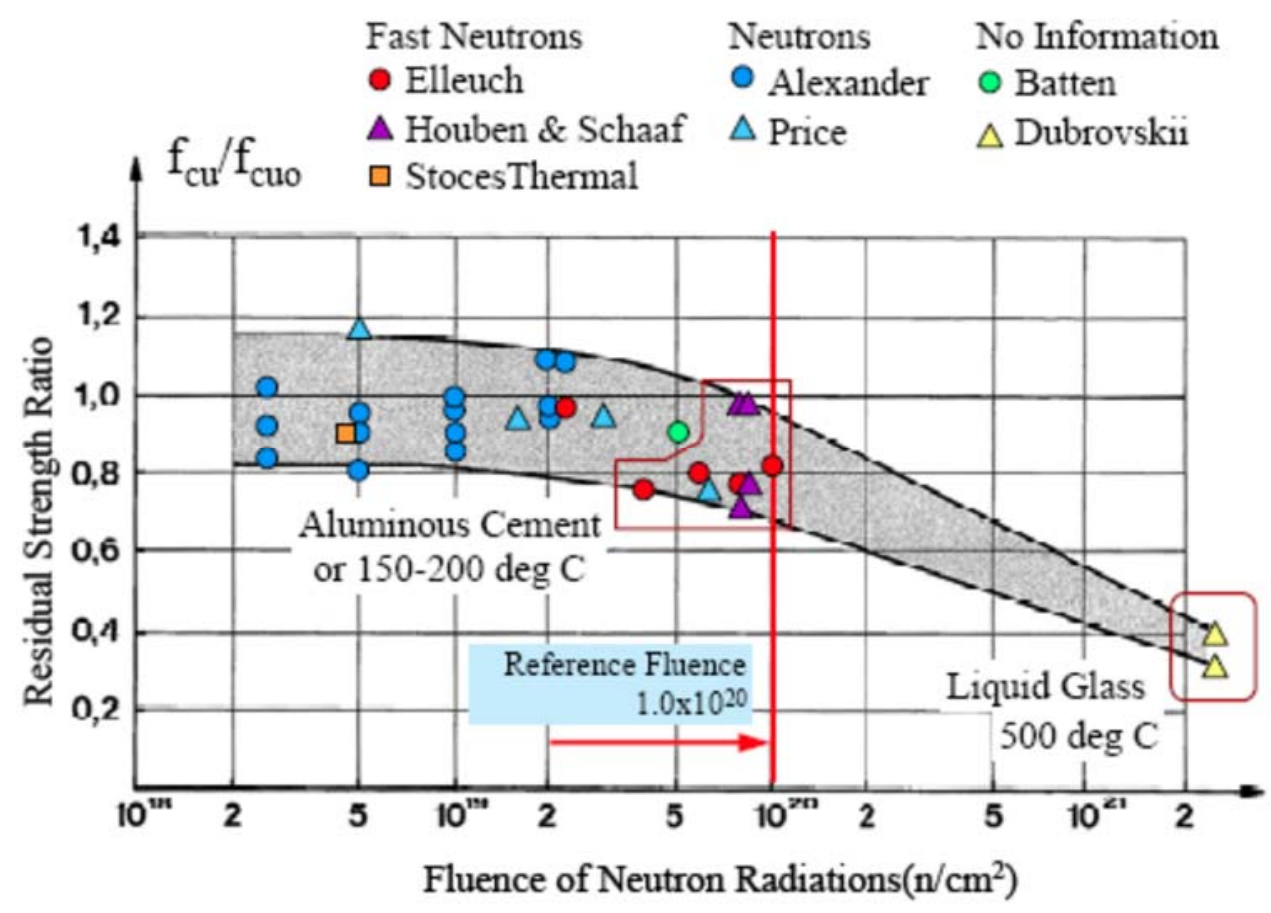

Figure 5-3: Compressive strength data points from Hilsdorf [19] paper that may not be representative of commercial LWRs (Reprinted from [2]) 
The Kontani re-plot of the neutron data, though, combined data for fast neutrons, slow neutrons, and data without the energy being specified. The comparison of all this data on the same curve is not desirable.

Recently, additional research performed in Japan and reported by Fujiwara et. al. [1] has added useful well documented data to the data that had been previously used by Hilsdorf. The testing was performed at the Japan Materials Testing Reactor (JMTR). JMTR is a light-water cooled tank reactor. The temperature of the specimens was maintained below $65^{\circ} \mathrm{C}\left(150^{\circ} \mathrm{F}\right)$ during the testing. The fluence was selected at energy greater than $0.1 \mathrm{MeV}$. An energy of $>0.1 \mathrm{MeV}$ has become a norm for concrete testing around the world.

The test results are shown in Figure 5-4. The tests were performed up to a neutron fluence $(E>0.1 \mathrm{MeV})$ of $1.2 \mathrm{E}+19 \mathrm{n} / \mathrm{cm}^{2}$. As is evident in Figure 5-4, no reduction in compressive strength of the concrete was noted.

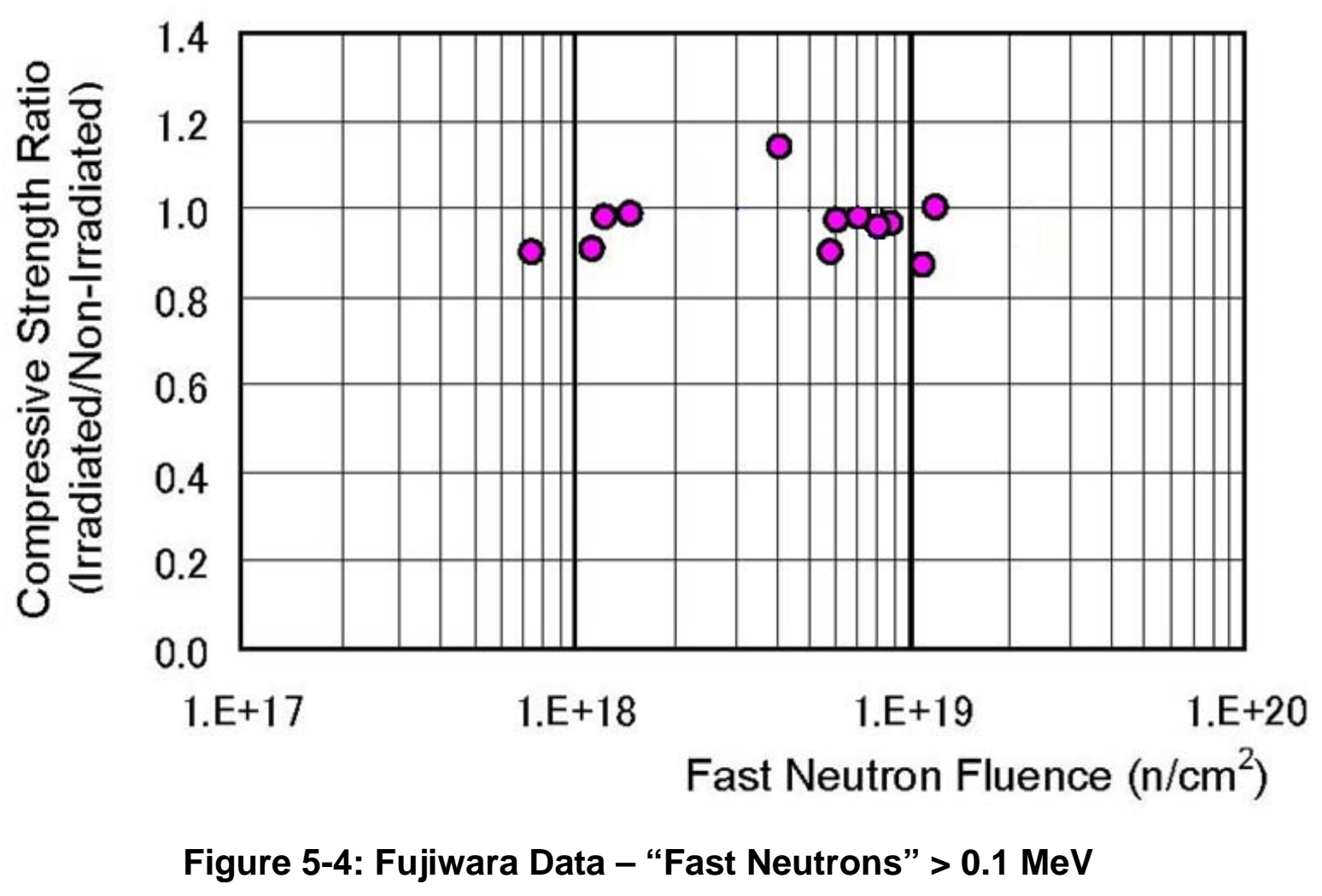

Report No. A13276-R-001

Revision 0 


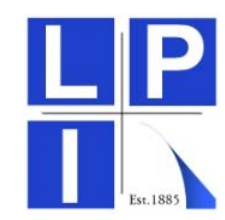

The only other data that may be plotted on this curve was data from Dubrovskii [20]. This work was not included in the Hilsdorf curves. Dubrovskii reported on testing on "Ordinary Concrete". The concrete tested was made from Portland cement with sandstone as an aggregate. The temperature of the testing varied from $50^{\circ} \mathrm{C}$ to $200^{\circ} \mathrm{C}$, but they tested concrete that was exposed to the same temperature but was unirradiated for comparison. In the paper, "fast neutrons" were defined as those with energy greater than $0.8 \mathrm{MeV}$. Dubrovskii concluded that "the investigation of the radiation resistance of ordinary concrete made of Portland cement and an aggregate consisting of sandstone and river sand showed that for irradiation of the concrete by a total neutron flux less than $5 \times 10^{19} \mathrm{n} / \mathrm{cm}^{2}$ (fast neutron flux $[>0.8 \mathrm{MeV}], 5 \times 10^{17} \mathrm{n} / \mathrm{cm}^{2}$ ), the changes in the properties of this material are insignificant, and it can be recommended for use in load-bearing shield construction." The temperature range of the tests of the samples irradiated to this level was between $20^{\circ} \mathrm{C}$ and $50^{\circ} \mathrm{C}$. Other samples that were tested were up to temperatures of $350^{\circ} \mathrm{C}$ and were not considered representative.

The Dubrovskii tests were performed in the BR-5 reactor and that paper defined the "Energy Distribution of Neutrons Incident on Sample". That table was used to approximate the neutron exposure with energy greater than $0.1 \mathrm{MeV}$. The neutron exposure with energy $>0.1 \mathrm{MeV}$ that corresponds to a "fast neutron flux" is $2.3 \mathrm{E}+19 \mathrm{n} / \mathrm{cm} 2(\mathrm{E}>0.1 \mathrm{MeV})$. The average strength of the irradiated samples at this fluence level was $4 \%$ higher than the average strength of the unirradiated samples. This data point can reliably be placed on the curve with the Fujiwara data.

With the Dubrovskii data, the data that accurately represents the compressive strength of irradiated concrete following neutron irradiation with energy greater than $0.1 \mathrm{MeV}$ and temperatures less than $100^{\circ} \mathrm{C}$ is shown in Figure 5-5. 


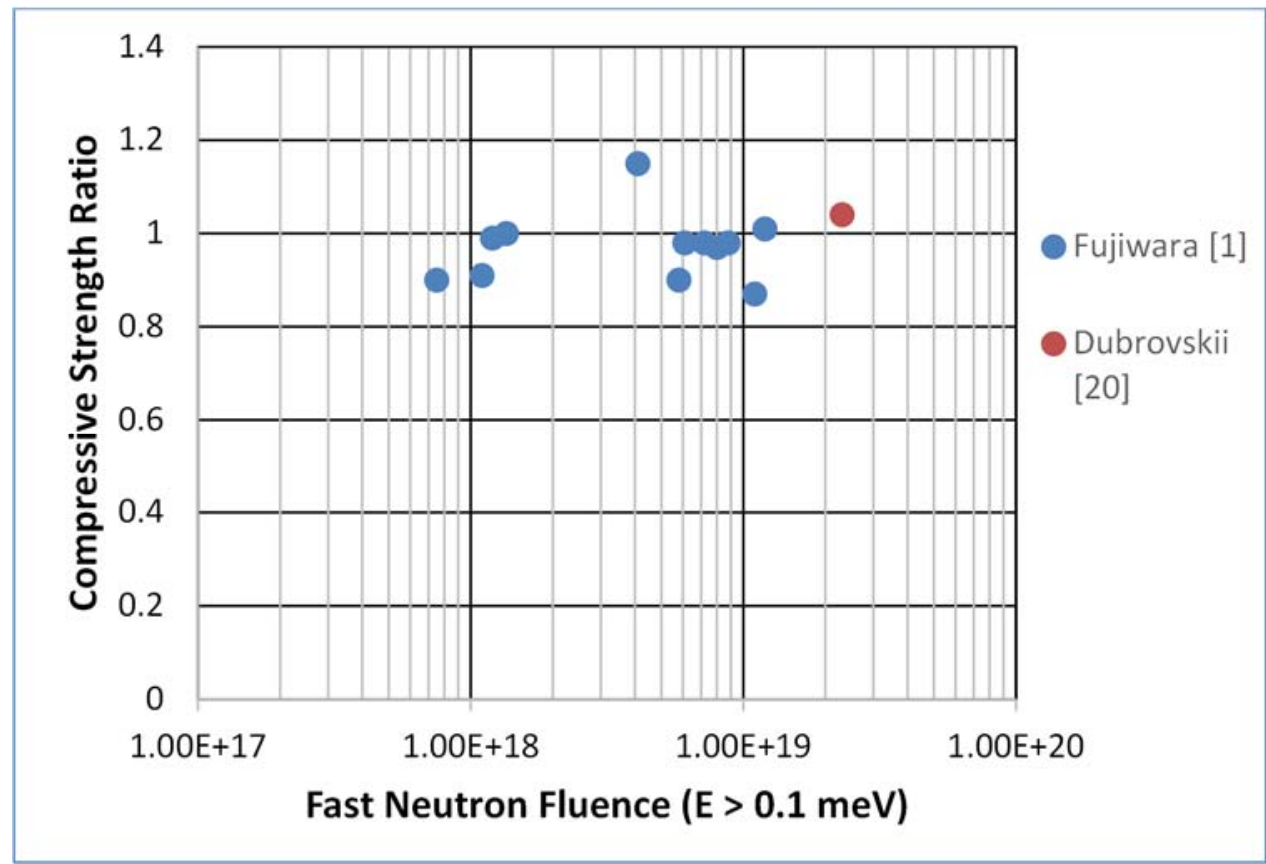

Figure 5-5: Concrete Compressive Strength Data following exposure to Neutron Radiation ( $E>0.1 \mathrm{MeV}$ )

The evaluation of the data indicates that a lack of uniformity of the early data used by Hilsdorf and the lack of information on the test conditions and the energy of the fluence prevents the reliable use of most of the early data. The data shown in Figure 5-5 is judged to be reliable and consistent and should provide a foundation for future understanding of the effects of radiation. Additional data that is for representative concrete, representative conditions, and known to be for neutron fluence for energies greater than $0.1 \mathrm{MeV}$ should be sought.

\subsection{Gamma Test Results}

Hilsdorf [19] also presented a summary of gamma testing. The Hilsdorf gamma curve is shown in Figure 5-2. The data that was used is varied and not representative of commercial reactor conditions. The Sommers [21] data provided an indication of a decline in compressive strength. Those tests were performed with concrete in direct contact with deionized water and the samples showed significant effects of water degradation. The Gray [22] data was for concrete tested in tension and is not pertinent to define the change in compressive strength. Without this data, there is not adequate data to state that the compressive strength would be reduced. 
Kontani [2] also reviewed this data in detail and concluded that the Sommers data was not representative. Kontani highlighted the Hilsdorf gamma curve with this information. This is shown in Figures 5-5. If the data points that were highlighted by Kontani as unrepresentative were removed, the trend of decreasing strength with increasing gamma dose would be less well defined. Although less well defined, a threshold value of approximately $2.0 \mathrm{E}+10$ rads, as suggested by Kontani [2], seems conservative.

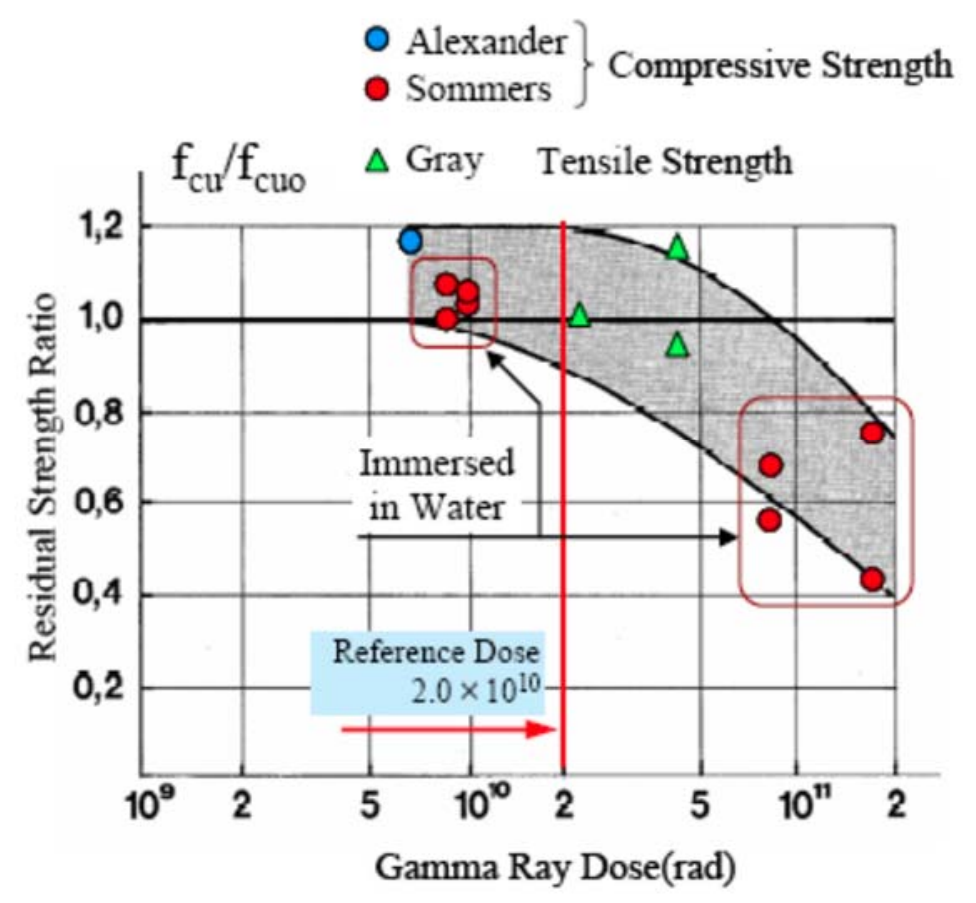

Figure 5-5: Gamma dose data points from Hilsdorf [19] paper that may not be representative of commercial LWRs (reprinted from [2])

Some more recent testing has been performed. Soo and Milian [23] tested Portland cement mortars and described a reduction of strength that was postulated to be caused by the radiolysis of water. Their data on compressive strength of the cement paste is shown in Figure 5-6. They showed a reduction in strength at a gamma exposure of $1 \mathrm{E}+9$ rads when tested at a dose rate of 3.8 $\mathrm{E}+5$ rads per hours. A reduction of strength at a gamma exposure of 2.0 $\mathrm{E}+7$ rads when tested at a dose rate of $3.1 \mathrm{E}+3 \mathrm{rads} / \mathrm{hr}$. was also reported. This testing on cement paste must be augmented with testing of the paste with aggregate as would be used in prototypical concrete to provide insight into the performance of concrete. 


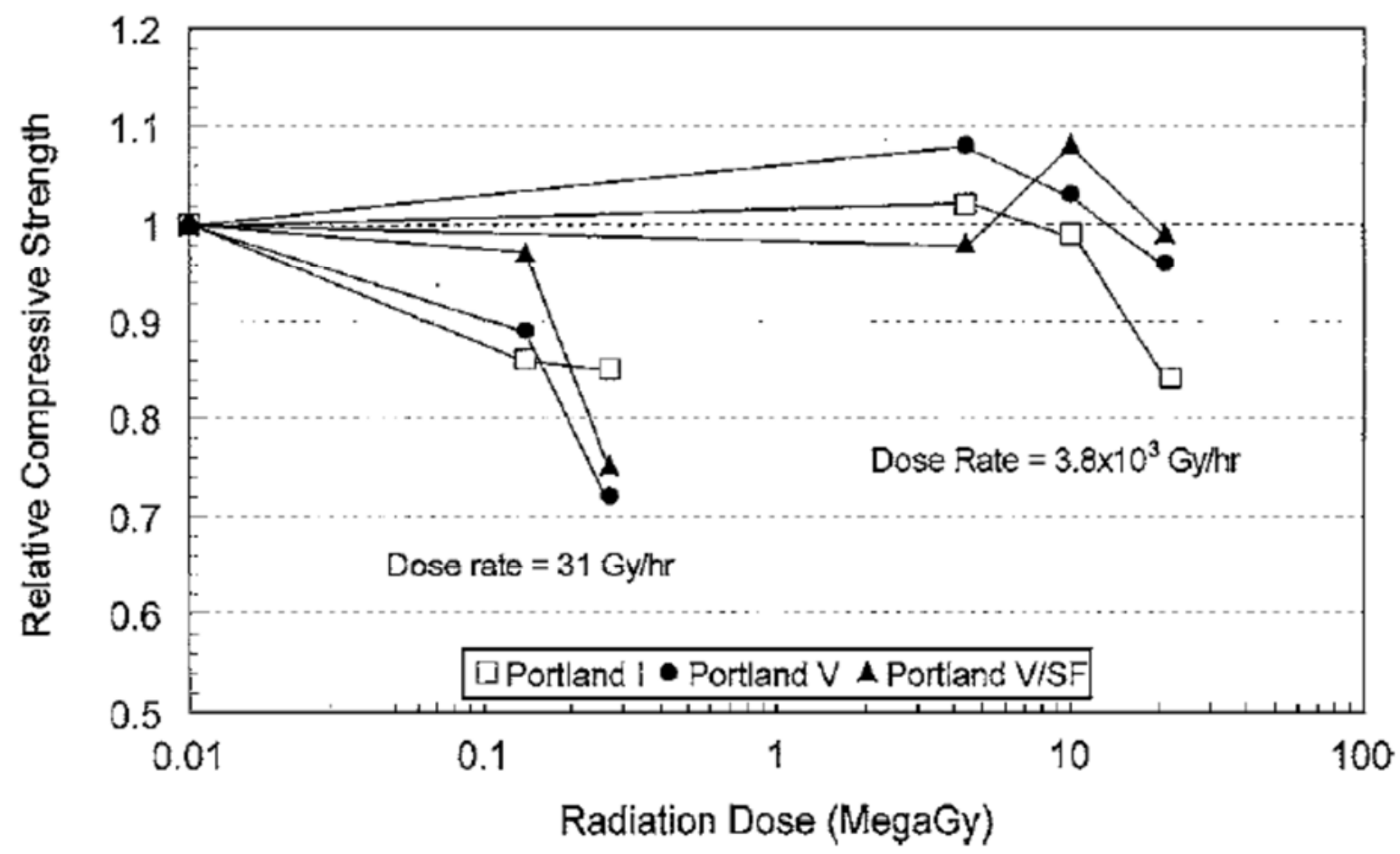

Figure 5-6: Data from Soo and Milian [23] shows reduction in strength at 1 $\mathrm{E}+9 \mathrm{rads}$ (10 MegaGy) for a dose rate of $3.8 \mathrm{E}+5 \mathrm{rads}$ per hours (3.8 E+3 Gy per hour)

Other test results from Sopko, et. al. [24] showed compressive strength reduction of concrete specimens starting at a gamma exposure of $3.0 \mathrm{E}+7$ rads. The dose rate was reported to be between $2.5 \mathrm{E}+4$ rads per hour and $9.35 \mathrm{E}+4$ rads per hour ( $0.935 \mathrm{kGy}$ per hour). These tests were performed on concrete beams with dimension of $0.4 \times 0.1 \times 0.1 \mathrm{~m}(15.8 \times 3.9 \times 3.9$ inches $)$. They were first tested in three point bending and then the ends were tested in tension and compression. 


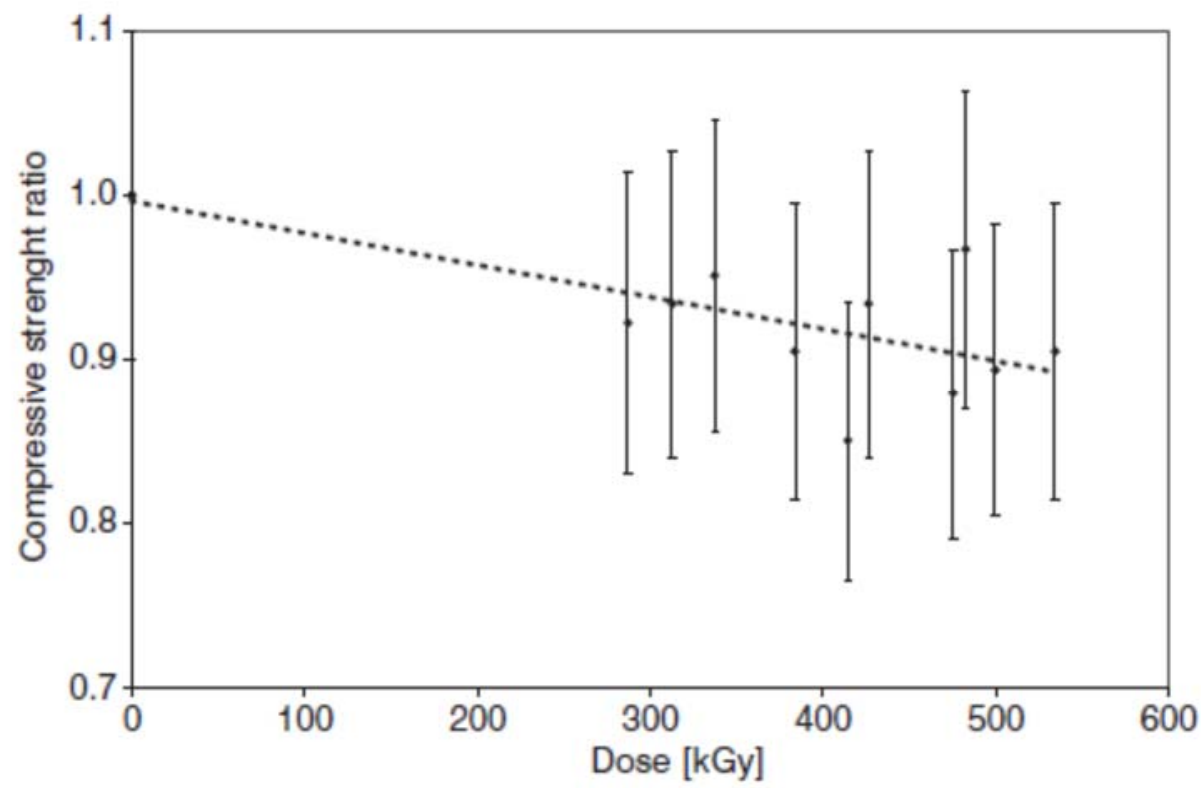

Figure 5-7: Data from Sopko, et. al. [24] shows continual reduction in strength starting at $3.0 \mathrm{E}+7$ rads (300 kGy)

More recent work reported by Kontani et. al. [25] studied water retention in cement paste. This is important work that will supplement the knowledge on the effect that radiation has on concrete materials. They state that they intend to perform physical property tests on concrete for the effects of gamma irradiation in the future.

Inadequate test results for the effect of gamma are currently available. Additional data that is for representative concrete, representative conditions, and gamma exposure should be sought. 


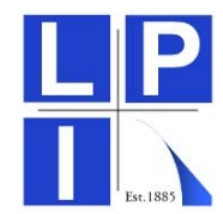

\section{CONCRETE MATERIAL CHARACTERIZATION}

This section considers the main constituents of concrete. These are cement, large aggregate (gravel), small aggregate (sand), and water. Additionally, concrete used at a sample of US nuclear plants is described. The characteristics of prototypical are reviewed and presented to provide information on composition. Material that could be considered as representative of the fleet is described to assist in material selection for future testing.

Concrete consists of aggregates bound together by a cementitious material. Different types of cement could have been used in concrete for reactor radiation shielding (typically referenced as reactor cavity concrete, reactor shield concrete, biological shield concrete), including Portland cement, high-alumina cement, specialty cements, and others. For this study, concrete from plants with US geographical diversity was evaluated based on information contained in NUREG/CR-3474 [26]. This reference presented data on concrete from currently operating plants as well as plants that have been decommissioned or had started construction but were not completed. They are considered to be representative of the currently operating plants in the United States. This information was supplemented with a review of concrete information from additional reactor sites [27], together with data from ORNL [28], Crystal River [29], and Trojan [30]. Collectively the reviewed data provides good geographical representation to supplement information of NUREG/CR-3474 [26].

From this review, recommendations are made relative to typical concrete characteristics and constituents that could be used for development of samples for future radiation testing.

Based on a review of concretes from NUREG/CR-3474 [26], together with the other plant sites reviewed [27 to 30], only one currently operating commercial reactor (Susquehanna) was identified as having used a high density aggregate.

\subsection{Cement}

There are many different types of cements used in the construction industry, by far the most important, in-terms of quantity used is Portland cement, and cement that is based on Portland cement [31]. Portland cement has typically been specified as the cement for concrete mixes at US nuclear plants. Cement can be "pure" Portland cement, or alternatively may be made from Portland cement mixed with other materials, with cementitious properties, including blast furnace slag from iron smelting or fly ash from coal-fired power stations. Cements composed of mixtures can enhance concrete properties.

Report No. A13276-R-001

Revision 0

Page 58 of 92 
Portland cement is made by heating suitable raw materials (typically limestone and clay) at a temperature of approximately $2,640^{\circ} \mathrm{F}\left(1,450^{\circ} \mathrm{C}\right)$ to produce clinker. The clinker is ground to a fine powder and a small amount of gypsum is added to control setting properties. A typical analysis of Portland cement is shown in Table 6-1 and compared to cement analysis from a sample of the study plants. A comparison of Portland cement element percentages to the cement evaluated from study plants is shown in Figure 6-2. The chemical similarity confirms the wide spread use of Portland cement.

Portland cement is primarily manufactured from a calcareous material [32]. Limestone and chalk are the two principal examples of calcareous material. Clay or shale provides the silica and alumina to Portland cement. The main compounds of Portland cement include: tricalcium silicate $\left(3 \mathrm{CaO} \cdot \mathrm{SiO}_{2}\right)$; dicalcium silicate $\left(2 \mathrm{CaO} \cdot \mathrm{SiO}_{2}\right)$; tricalcium aluminate $\left(3 \mathrm{CaO} \cdot \mathrm{Al}_{2} \mathrm{O}_{3}\right)$; and tetracalcium aluminoferrite $\left(4 \mathrm{CaO} \cdot \mathrm{Al}_{2} \mathrm{O}_{3} \cdot \mathrm{Fe}_{2} \mathrm{O}_{3}\right)$;

In the presence of water the Portland cement compounds hydrate. After the cement paste has set the hydration process continues and the paste hardens. The main hydration reactions are:

$$
\begin{aligned}
& \left(6 \mathrm{CaO} \cdot 2 \mathrm{SiO}_{2}\right)+6 \mathrm{H}_{2} \mathrm{O} \rightarrow\left(3 \mathrm{CaO} \cdot 2 \mathrm{SiO}_{2} \cdot 3 \mathrm{H}_{2} \mathrm{O}\right)+\left(3 \mathrm{CaO} \cdot 3 \mathrm{H}_{2} \mathrm{O}\right) \\
& \left(4 \mathrm{CaO} \cdot 2 \mathrm{SiO}_{2}\right)+4 \mathrm{H}_{2} \mathrm{O} \rightarrow\left(3 \mathrm{CaO} \cdot 2 \mathrm{SiO}_{2} \cdot 3 \mathrm{H}_{2} \mathrm{O}\right)+\left(\mathrm{CaO} \cdot \mathrm{H}_{2} \mathrm{O}\right) \\
& \left(3 \mathrm{CaO} \cdot \mathrm{Al}_{2} \mathrm{O}_{3}\right)+6 \mathrm{H}_{2} \mathrm{O} \rightarrow\left(3 \mathrm{CaO} \cdot \mathrm{Al}_{2} \mathrm{O}_{3} \cdot 6 \mathrm{H}_{2} \mathrm{O}\right)
\end{aligned}
$$

The hydrates of the various compounds contained in the cement paste are referred to as the cement gel. The gel consists of gel particles and interstitial voids that contain water and which are referred to as gel pores [18]. Also present are voids, called capillary pores, which contain the excess water that has not chemically combined with the mineral compounds and which is not present in the gel pores [31]. The density of unhydrated Portland cement is normally between $3.0-3.2 \mathrm{~g} / \mathrm{cm}^{3}$. Hydrated paste has a nominal density of 2.0 $\mathrm{g} / \mathrm{cm}^{3}$.

A number of the study plants (Palo Verde, Enrico Fermi, Hartsville, and Bellefonte) reported use of fly ash [26]. Typical specification calls for less than $5 \%$ by volume of fly ash added to the cement. Its use is beneficial for a number of reasons, including improved concrete workability, reduced permeability and increases its resistance to sulfate attack and alkali-silica reaction. The 


\section{LP \\ II...}

difference in element composition for fly ash cement to non-fly ash cement (Table 6-1) is not significant.

\subsection{Large and Fine Aggregate}

The fine and coarse aggregates generally occupy $60 \%$ to $75 \%$ of the concrete volume ( $70 \%$ to $85 \%$ by mass) and strongly influence the concrete's freshly mixed and hardened properties.

Large or coarse aggregate used in the manufacture of concrete at nuclear plants is generally typical of whatever rock can be quarried locally and economically. The high costs associated with the use of high density aggregate has resulted in a far more limited use than was common in the early stages of reactor plant development ${ }^{3}$. Of the study plants [26], the additional reviewed plants [27] and the ORNL database plants [28], Crystal River [29], Trojan [30], only Susquehanna used high density aggregate, identified in NUREG/CR-3474 as ilmenite and magnetite.

A review of the coarse aggregate main element percentages of select study plants is shown in Table 6-3 [26]. Geological differences between quarry sites are evident. For instance, the WPPSS site uses a basalt aggregate, whereas other sites (Turkey Point, Bellefonte, and Hartsville, as examples) clearly use a limestone aggregate with higher percentages of calcium (Ca) evident.

A review of a US aggregate map [33], Figure 6-3 provides regions of typical aggregate, contoured into 5 categories, based on the Mohs hardness of the aggregate. The study plants [26] [28] [29] [30] are depicted on Figure 6-3. Contrasting this to the locations of US fleet nuclear plants all five classifications of aggregates would be expected to be represented. Close to half of the coarse aggregates used in Portland cement concrete in North America are gravels, most of the remainder are crushed stones [33].

The chemical analysis of selected study plants were compared, Figure 6-4 and the aggregate used can be sorted into three "bins", plants clearly using an aggregate high in silica, limestone aggregate and plants with some other type of aggregate, generally fitting between these two "aggregate types".

\footnotetext{
${ }^{3}$ A discussion on the use of concretes used for radiation shielding common in earlier nuclear plant designs is discussed in [32] and [18]. Many of these "earlier" plants are no longer operational and will not be considered for an 80 year life. As identified in [26], Susquehanna plant used high density aggregate.
}

Report No. A13276-R-001

Page 60 of 92

Revision 0 


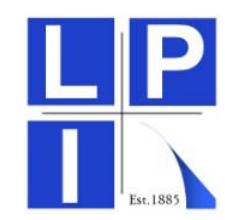

Fine aggregates generally consist of natural sand or crushed stone with most particles smaller than $5 \mathrm{~mm}$ (0.2 in.). Normal weight aggregates should meet the requirements of ASTM C-33 [35.a]. For adequate consolidation of concrete, the desirable amount of air, water, cement, and fine aggregate should be about $50 \%$ to $65 \%$ by absolute volume. Fine aggregate content is usually $35 \%$ to $45 \%$ by mass or volume of the total aggregate content [33].

A review of the fine aggregate main element percentages of select study plants [26] shows a similar composition between the coarse and fine aggregate, except at Wolf Creek and Susquehanna. The differences between coarse and fine aggregates are contrasted in Figure 6-5.

\subsubsection{Heavy Aggregates Used for Radiation Shielding}

Earlier plant designs utilized element additions to the concrete to increase density. One method to increase density is by the incorporation of heavy aggregates into the concrete mix. For protection from neutron radiation the optimization of concrete composition is not as straightforward. Materials of low atomic weight, such as hydrogen (in the form of water as an example), are required to reduce moderately fast neutrons of intermediate energy to slow neutrons of thermal energy [18]. In addition, materials are needed that can effectively absorb thermal neutrons without producing high-energy secondary gamma radiation as a consequence of the process. Boron is one element especially effective at the latter. Finally, materials of medium to high atomic weight are also needed to attenuate the secondary gamma radiation resulting from the capture of activated thermal neutrons [18]. Table 6-2 lists some of the typical aggregates used for concrete radiation shielding. This Table also identifies if the aggregate is covered by ASTM C-637: Standard Specification for Aggregates for Radiation Shielding Concrete [35.k].

The plants evaluated for this study were assessed relative to use of high density aggregate, Table 6-3, confirming its limited use.

\subsection{Concrete}

The main chemical analysis of the concrete samples from the selected study plants was evaluated [26] and is shown in Table 6-2. Differences in compositions are evident, based on differences in the aggregates utilized as was outlined in Section 6.2. These are depicted in Figure 6-6 and Figure 6-7. 


\subsubsection{Concrete Property Specification}

Concrete property specification was not reported in [26]. As such, data within the ORNL database [28], Trojan [30] and Crystal River [29] reports was reviewed, together with a review of concrete specifications from certain other sites [27].

Concrete requirements are typically outlined in plant specifications. These specifications usually detail requirements relative to concrete specific standards, as shown in Table 6-4. A review of a sample of plant concrete specification requirements are summarized in Table 6-5.

\subsubsection{Concrete Characterization}

As outlined above, some broad characterizations can be made of the study plants:

Portland cement was widely used for all study plants [26], the ORNL plants [28], and other plants reviewed [27], [29], [30]. The majority of the plants reviewed specified a Type II Portland cement, consistent with ASTM C-150 requirements. A number of the plants reviewed included fly ash to ASTM C-618 requirements, with air entrainment and water reduction admixtures to ASTM C-260 and C-494, respectively.

Aggregate can be categorized as containing high silica, or limestone, with some plant concretes having elements between these two groups.

Typical 28-day compressive strength was specified between 3,000 and 4,000 psi.

Water to cement $(\mathrm{W} / \mathrm{C})$ ratios were not readily available. 


\section{LIP}

Table 6-1: Typical Portland Cement Elements (weight)

\begin{tabular}{|l|c|c|c|c|c|c|c|c|c|}
\hline \multicolumn{1}{|c|}{ Element } & Symbol & $\begin{array}{c}\text { Ref } \\
\text { Portland }\end{array}$ & WPPSS & Bellefonte & Hartsville & $\begin{array}{c}\text { Wolf } \\
\text { Creek }\end{array}$ & $\begin{array}{c}\text { Palo } \\
\text { Verde }\end{array}$ & $\begin{array}{c}\text { Enrico } \\
\text { Fermi }\end{array}$ & Susquehanna \\
\hline Sodium & $\mathrm{Na}$ & $0.12 \%$ & $0.08 \%$ & $0.09 \%$ & $0.14 \%$ & $0.25 \%$ & $0.10 \%$ & $0.24 \%$ & $0.20 \%$ \\
\hline Aluminum & $\mathrm{Al}$ & $3.02 \%$ & $2.30 \%$ & $2.50 \%$ & $2.40 \%$ & $2.20 \%$ & $2.20 \%$ & $2.60 \%$ & $2.20 \%$ \\
\hline Silicon & $\mathrm{Si}$ & $9.66 \%$ & $11.00 \%$ & $10.40 \%$ & $11.40 \%$ & $10.90 \%$ & $10.00 \%$ & $10.90 \%$ & $10.70 \%$ \\
\hline Phosphorus & $\mathrm{P}$ & & $0.60 \%$ & $0.60 \%$ & $0.60 \%$ & $0.70 \%$ & $0.60 \%$ & $0.60 \%$ & $0.60 \%$ \\
\hline Sulphur & $\mathrm{S}$ & $1.08 \%$ & $1.40 \%$ & $1.30 \%$ & $0.88 \%$ & $1.00 \%$ & $1.60 \%$ & $1.10 \%$ & $1.10 \%$ \\
\hline Potassium & $\mathrm{K}$ & $0.50 \%$ & $0.56 \%$ & $0.49 \%$ & $0.40 \%$ & $0.27 \%$ & $0.22 \%$ & $0.70 \%$ & $0.60 \%$ \\
\hline Calcium & $\mathrm{Ca}$ & $45.71 \%$ & $41.60 \%$ & $45.50 \%$ & $46.10 \%$ & $46.00 \%$ & $48.50 \%$ & $45.30 \%$ & $46.10 \%$ \\
\hline Iron & $\mathrm{Fe}$ & $1.75 \%$ & $2.17 \%$ & $1.86 \%$ & $2.00 \%$ & $3.35 \%$ & $2.12 \%$ & $1.78 \%$ & $2.29 \%$ \\
\hline
\end{tabular}




\section{LPP \\ I.}

Table 6-2: Special aggregates for radiation-shielding concrete (adapted from [33])

\begin{tabular}{|c|c|c|c|c|c|}
\hline Aggregate & Type of Material & Chemical Composition & $\begin{array}{l}\text { Fixed Water } \\
\text { (\% by weight) }\end{array}$ & $\begin{array}{l}\text { Specific } \\
\text { Gravity }\end{array}$ & $\begin{array}{l}\text { ASTM } \\
\text { C637 }\end{array}$ \\
\hline Serpentine & Natural, hydrous & $3 \mathrm{MgO} .2 \mathrm{SiO}_{2} .2 \mathrm{H}_{2} \mathrm{O}$ & 10 to $13^{*}$ & 2.4 to $2.65^{*}$ & Yes \\
\hline Limonite & Natural, hydrous & $2 \mathrm{Fe}_{2} \mathrm{O}_{3} .3 \mathrm{H}_{2} \mathrm{O}$ & 8 to $12^{*}$ & 3.4 to $3.8^{*}$ & Yes \\
\hline Goethite & Natural, hydrous & $\mathrm{Fe}_{2} \mathrm{O}_{3} \cdot \mathrm{H}_{2} \mathrm{O}$ & 8 to $12^{*}$ & 3.5 to 4.5 & Yes \\
\hline Bauxite & Natural, hydrous & $\mathrm{Al}_{2} \mathrm{O}_{3} .2 \mathrm{H}_{2} \mathrm{O}$ & 15 to 25 & 1.8 to 2.3 & No \\
\hline Hematite & Natural, heavy & $\mathrm{Fe}_{2} \mathrm{O}_{3}$ & - & 4.6 to $5.2^{*}$ & Yes \\
\hline Magnetite & Natural, heavy & $\mathrm{Fe}_{3} \mathrm{O}_{4}$ & - & 4.6 to $5.2^{*}$ & Yes \\
\hline Ilmenite & Natural, heavy & $\mathrm{FeO} . \mathrm{TiO}_{2}$ & - & 4.2 to $4.8^{*}$ & Yes \\
\hline Barytes & Natural, heavy & $\mathrm{BaSO}_{4}$ & - & 4.0 to $4.4^{*}$ & Yes \\
\hline Witherite & Natural, heavy & $\mathrm{BaCO}_{3}$ & - & 4.3 (approx.) & No \\
\hline $\begin{array}{l}\text { Ferro } \\
\text { phosphorus }\end{array}$ & Manufactured, heavy & $\mathrm{FeP}, \mathrm{Fe}_{2} \mathrm{P}$, or $\mathrm{Fe}_{3} \mathrm{P}$ & - & 5.8 to $6.3^{*}$ & Yes \\
\hline IronISteel & Manufactured, heavy & $\mathrm{Fe}$ & - & 6.5 to $7.5^{\star}$ & Yes \\
\hline Colemanite & Natural, boron & $2 \mathrm{CaO} .3 \mathrm{~B}_{2} \mathrm{O}_{3} .5 \mathrm{H}_{2} \mathrm{O}$ & - & 2.3 to 2.4 & No \\
\hline Borocalcite & Natural, boron & $\mathrm{CaO} .2 \mathrm{~B}_{2} \mathrm{O}_{3} .4 \mathrm{H}_{2} \mathrm{O}$ & - & 2.3 to 2.4 & No \\
\hline Boron-frit & Manufactured, boron & $\mathrm{B}_{2} \mathrm{O}_{3}, \mathrm{Al}_{2} \mathrm{O}_{3}, \mathrm{SiO}_{2}, \mathrm{CaO}$ & - & 2.6 to $2.8^{*}$ & Yes \\
\hline Boron-carbide & Manufactured, boron & $\mathrm{B}_{6} \mathrm{C}, \mathrm{B}_{4} \mathrm{C}$, or $\mathrm{B}_{3} \mathrm{C}$ & - & 2.4 to 2.6 & No \\
\hline Ferroboron & Manufactured, boron & $\begin{array}{l}\text { 90\% Fe and 10\% B } \\
\text { (approx.) }\end{array}$ & - & 5.0 (approx.) & No \\
\hline
\end{tabular}




\section{LIP \\ I.}

Table 6-3: Typical Concrete Elements (weight) [26]

\begin{tabular}{|c|c|c|c|c|c|c|c|c|c|c|c|c|c|}
\hline Element & Sym. & WPPSS & $\begin{array}{c}\text { Rancho } \\
\text { Seco }\end{array}$ & $\begin{array}{l}\text { Belle } \\
\text { fonte }\end{array}$ & $\begin{array}{l}\text { Harts } \\
\text { ville }\end{array}$ & $\begin{array}{l}\text { Wolf } \\
\text { Creek }\end{array}$ & $\begin{array}{l}\text { Palo } \\
\text { Verde }\end{array}$ & $\begin{array}{l}\text { Enrico } \\
\text { Fermi }\end{array}$ & $\begin{array}{c}\text { Turkey } \\
\text { Point }\end{array}$ & $\begin{array}{l}\text { Path } \\
\text { finder }\end{array}$ & $\begin{array}{c}\text { Humboldt } \\
\text { Bay }\end{array}$ & $\begin{array}{l}\text { Water } \\
\text { ford }\end{array}$ & $\begin{array}{c}\text { Susque } \\
\text { hanna }\end{array}$ \\
\hline Sodium & $\mathrm{Na}$ & 0.076 & & 0.09 & 0.14 & 0.25 & 0.1 & 0.24 & 0.2 & & & & \\
\hline Aluminum & $\mathrm{Al}$ & 5.5 & 5.7 & 1.5 & 1.3 & 1.8 & 6.1 & 2 & 0.53 & 2.2 & 5.1 & 1.6 & 2.1 \\
\hline Silicon & $\mathrm{Si}$ & 21.5 & 23.9 & 3.9 & 4.2 & 12.3 & 26.7 & 9.2 & 8.5 & 25.4 & 20.3 & 32.4 & 12.7 \\
\hline Phosphorus & $\mathrm{P}$ & 0.81 & 0.92 & 0.5 & 0.5 & 0.9 & 0.5 & 0.2 & 0.2 & 0.1 & 0.1 & 0.4 & 0.2 \\
\hline Sulphur & $S$ & 0.46 & 0.44 & 0.26 & 0.33 & 0.25 & 0.27 & 0.42 & 0.2 & 0.2 & 0.2 & 0.43 & 0.3 \\
\hline Potassium & $\mathrm{K}$ & 1.2 & 1.1 & 0.29 & 0.31 & 0.93 & 2.5 & 0.6 & 0.047 & 0.61 & 0.84 & 0.08 & 0.5 \\
\hline Calcium & $\mathrm{Ca}$ & 14 & 12.3 & 32.4 & 34.7 & 26.8 & 9.2 & 17.5 & 29.4 & 8.3 & 8.5 & 12 & 15 \\
\hline Iron & $\mathrm{Fe}$ & 5 & 3.6 & 0.9 & 1.1 & 1.05 & 1.9 & 1.1 & 0.5 & 1.2 & 4.4 & 0.7 & $24(1)$ \\
\hline
\end{tabular}

Notes:

(1) Heavy aggregate 


\section{LPP \\ I.}

Table 6-4: Typical Plant Specification Standards

\begin{tabular}{|l|l|}
\hline \multicolumn{1}{|c|}{ Specification } & \multicolumn{1}{c|}{ Title } \\
\hline ACI 301 [34.a] & Specifications for Structural Concrete \\
\hline ACI 613 [34.b] & $\begin{array}{l}\text { ACI Standard Recommended Practice for the Design of Concrete } \\
\text { Mixes }\end{array}$ \\
\hline ASTM C-33 [35.a] & Standard Specification for Concrete Aggregates \\
\hline ASTM C-39 [35.b] & $\begin{array}{l}\text { Standard Test Method for Compressive Strength of Cylindrical } \\
\text { Concrete Specimens }\end{array}$ \\
\hline ASTM C-40 [35.c] & $\begin{array}{l}\text { Standard Test Method for Organic Impurities in Fine Aggregates for } \\
\text { Concrete }\end{array}$ \\
\hline ASTM C-94 [35.d] & Standard Specification for Ready-Mixed Concrete \\
\hline ASTM C-143 [35.e] & Standard Test Method for Slump of Hydraulic-Cement Concrete \\
\hline ASTM C-150 [35.f] & Standard Specification for Portland Cement \\
\hline ASTM C-231 [35.g] & $\begin{array}{l}\text { Standard Test Method for Air Content of Freshly Mixed Concrete by } \\
\text { the Pressure Method }\end{array}$ \\
\hline ASTM C-260 [35.h] & Standard Specification for Air-Entraining Admixtures for Concrete \\
\hline ASTM C-494 [35.i] & Standard Specification for Chemical Admixtures for Concrete \\
\hline ASTM C-618 [35.j] & $\begin{array}{l}\text { Standard Specification for Coal Fly Ash and Raw or Calcined } \\
\text { Natural Pozzolan for Use in Concrete }\end{array}$ \\
\hline ASTM C-637 [35.k] & $\begin{array}{l}\text { Standard Specification for Aggregates for Radiation Shielding } \\
\text { Concrete }\end{array}$ \\
\hline
\end{tabular}




\section{LPP \\ I.}

Table 6-5: Plant Concrete Specifications (Available Information)

\begin{tabular}{|c|c|c|c|c|c|c|c|c|}
\hline Plant & Location & Cement & Fly Ash & Admix. & $\begin{array}{c}\text { Air } \\
\text { Entrain. }\end{array}$ & $\begin{array}{l}\text { Aggregate } \\
\text { Type / Size }\end{array}$ & $\begin{array}{l}\text { Conc. Mix } \\
\text { IStrength. }\end{array}$ & Ref., Other Notes \\
\hline Trojan & OR & $\begin{array}{l}\text { C-150 } \\
\text { Type II }\end{array}$ & $\begin{array}{c}15 \% \text { by } \\
\text { wt to C- } \\
637\end{array}$ & & & $\begin{array}{l}\text { Willamette } \\
\text { River } \\
\text { Deposits } 0.75 " \\
\text { \& 1.5" size }\end{array}$ & $\begin{array}{c}6.0 \mathrm{ksi} \\
\text { (Containment) }\end{array}$ & $\begin{array}{c}\text { NUREG/CR-6598 } \\
{[30]}\end{array}$ \\
\hline $\begin{array}{l}\text { Crystal } \\
\text { River } 3 \\
\end{array}$ & $\mathrm{FL}$ & $\mathrm{ACl}-301$ & & & & & $\begin{array}{c}5.0 \mathrm{ksi} \\
\text { (Containment) }\end{array}$ & [29] \\
\hline Midland & MI & $\begin{array}{l}\text { C-150 } \\
\text { Type II }\end{array}$ & $\begin{array}{l}\text { C-618 } \\
\text { Class F }\end{array}$ & $\begin{array}{c}\text { C-494 } \\
\text { Type A }\end{array}$ & C-260 & $1.5 "$ & & $\begin{array}{c}\text { W/C ratio } 0.34 \\
\text { Slump } 3, \text { ORNL } \\
\text { Database }[28]\end{array}$ \\
\hline [27] & $\begin{array}{l}\text { Upper } \\
\text { Midwest }\end{array}$ & $\begin{array}{l}\text { C-150 } \\
\text { Type II }\end{array}$ & $C-150$ & & $\begin{array}{c}\text { C-260 } \\
\text { Air } \\
\text { Content } \\
3 \%\end{array}$ & $\begin{array}{c}\text { C-33 } \\
\text { Crushed } \\
\text { Dolomite } \\
0.75 " \& 1.5 "\end{array}$ & $\begin{array}{l}\mathrm{ACl}-613 \\
4-5 \mathrm{ksi}\end{array}$ & Mix per ACl-613 \\
\hline$[27]$ & Southeast & & & & & & $5.0 \mathrm{ksi}$ & \\
\hline [27] & Southeast & & & C-494 & C-260 & $\begin{array}{l}\text { C-33 } \\
1.0 "\end{array}$ & $4.0 \mathrm{ksi}$ & \\
\hline [27] & $\begin{array}{l}\text { Middle } \\
\text { South }\end{array}$ & $\begin{array}{l}\text { C-150 } \\
\text { Type II }\end{array}$ & & & & $\begin{array}{c}\text { C-33 } \\
0.75 " \text { \& 1.5" } \\
\text { C-40 }\end{array}$ & $4.0 \mathrm{ksi}$ & $\mathrm{ACl}-301$ \\
\hline [27] & Northeast & $\begin{array}{l}\text { C-150 } \\
\text { Type I, II, } \\
\text { or III }\end{array}$ & & & & $\begin{array}{c}\text { C-33 } \\
0.75^{\prime \prime}, 1.5^{\prime \prime}\end{array}$ & $3.0 \mathrm{ksi}$ & $\begin{array}{c}\text { ACl- } 613,614 \\
\text { C- } 94\end{array}$ \\
\hline [27] & Northeast & $\begin{array}{l}\text { C-150 } \\
\text { Type II }\end{array}$ & & C-494 & C-260 & $\begin{array}{l}\text { C-33 } \\
1.5^{\prime \prime}\end{array}$ & $4.0 \mathrm{ksi}$ & $\mathrm{ACl}-301$ \\
\hline
\end{tabular}




\section{LP \\ I.}

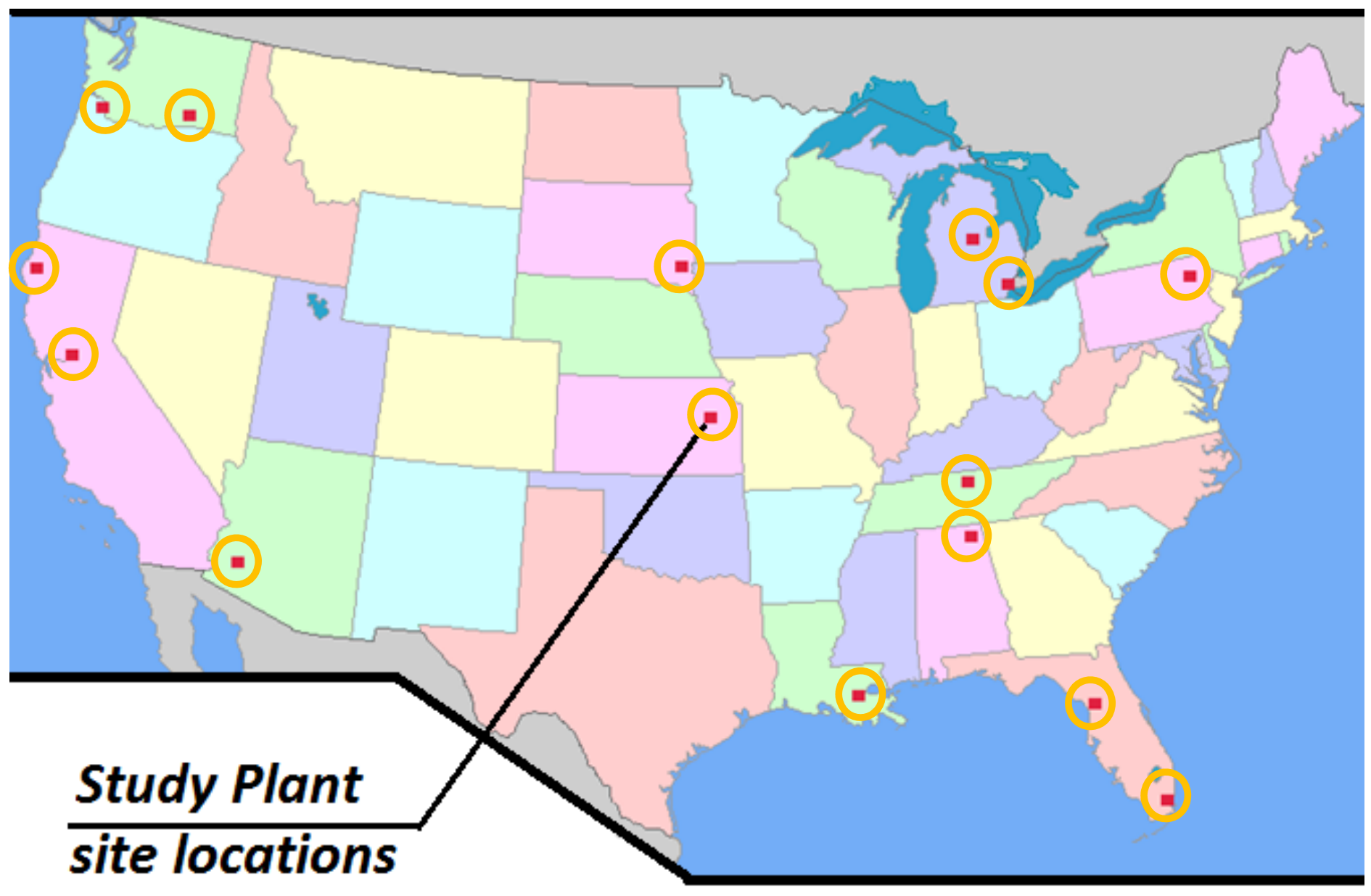

Figure 6-1: Geographic Representation of US Study Plant Locations 


\section{LP \\ I.}

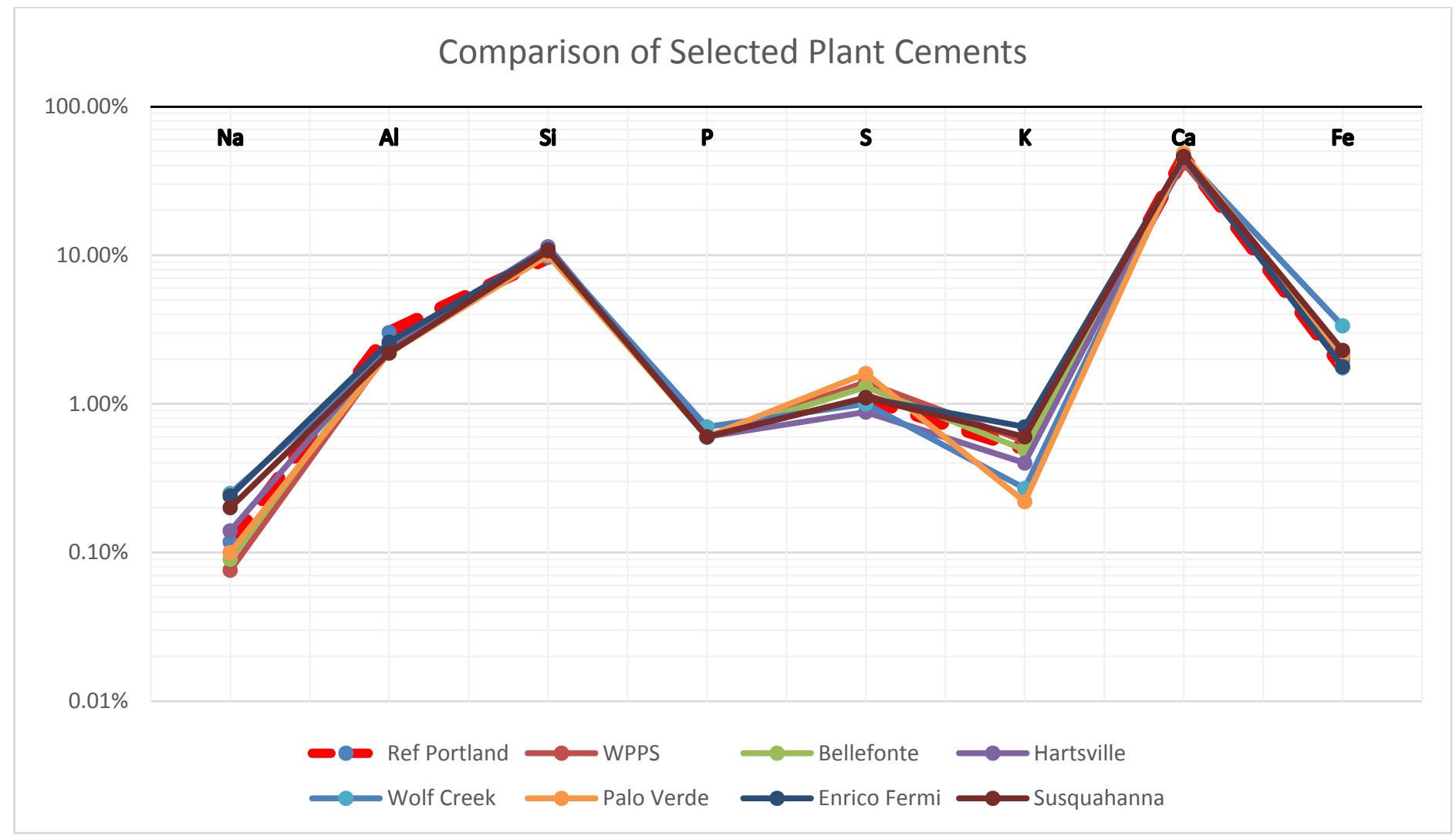

Figure 6-2: Comparison of Selected Plant Cement Elements to Portland cement "Reference Composition" 


\section{LPP \\ I.}

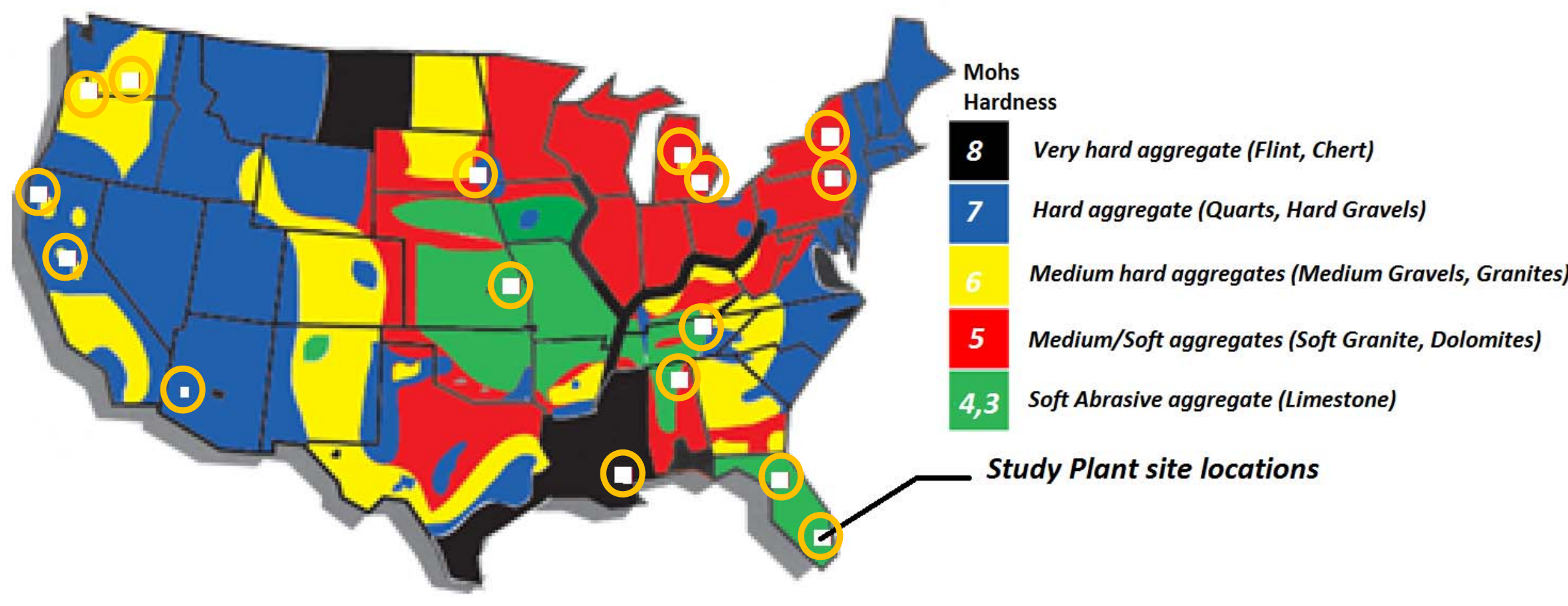

Figure 6-3: US Aggregate Map with Study Plants Located 


\section{LPP \\ I.}

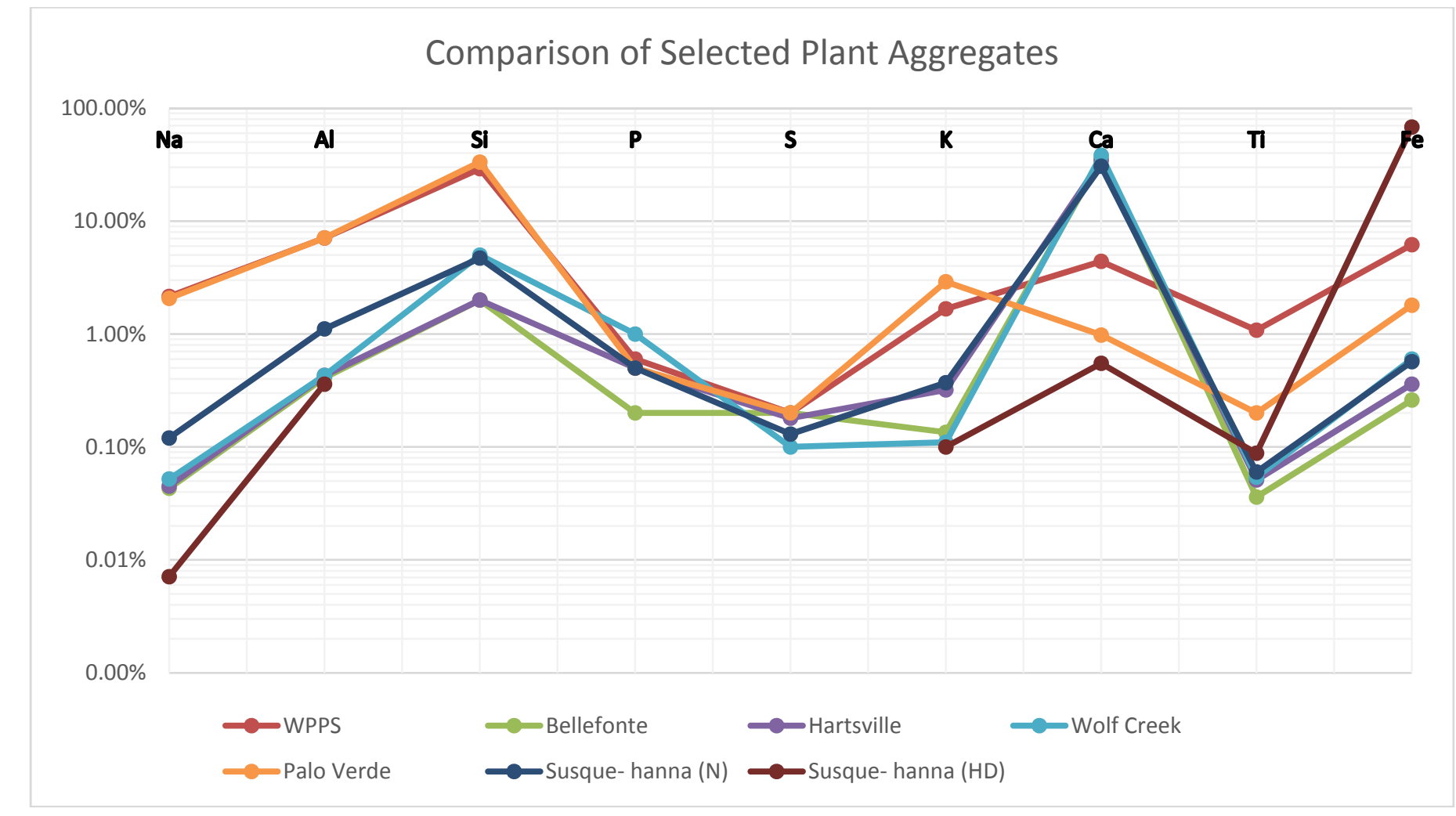

Notes: Susquehanna (N) and (HD) refer to Normal and High Density

Figure 6-4: Comparison of Selected Plant Aggregate Elements 


\section{LP \\ I.}

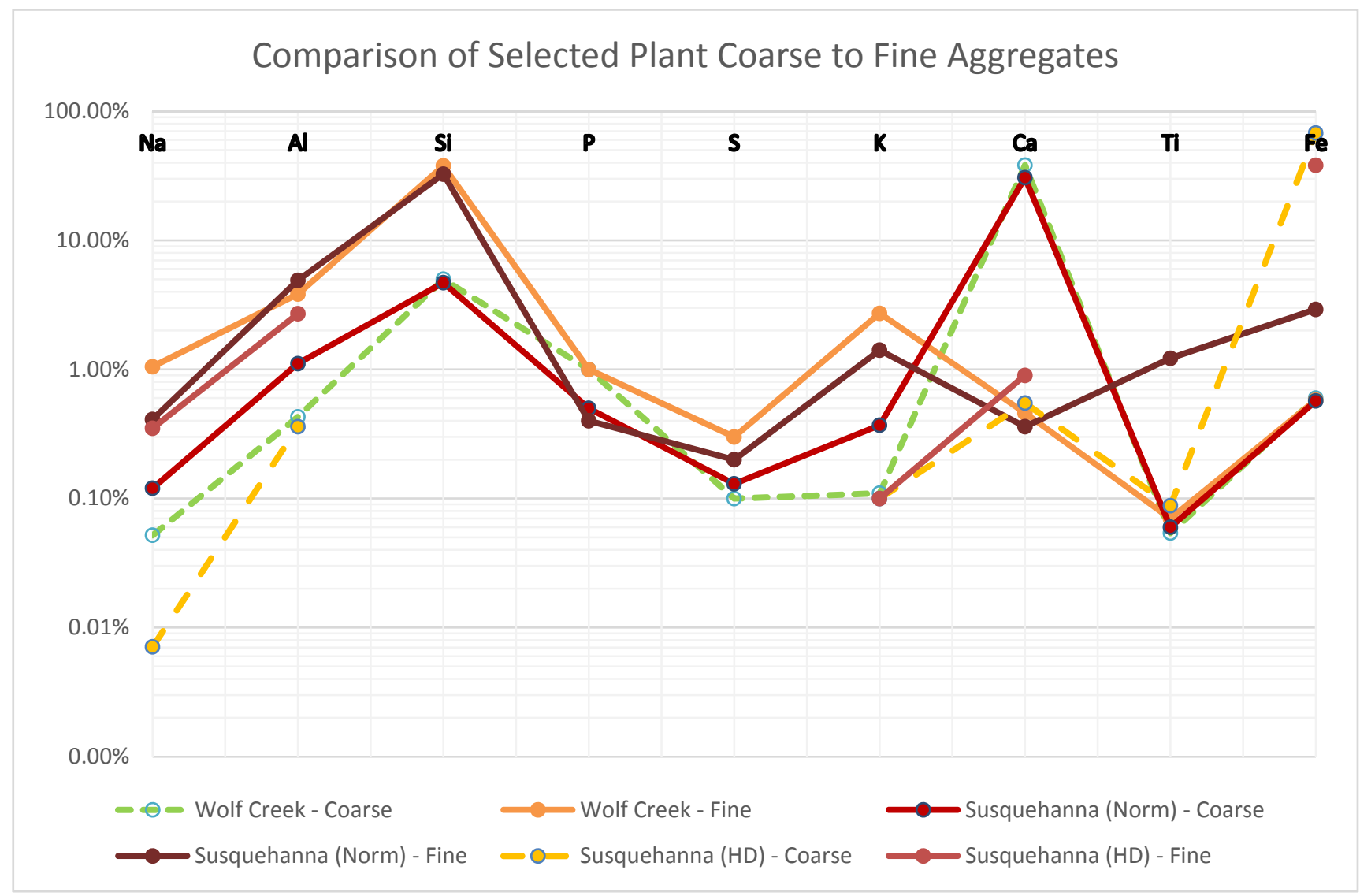

Figure 6-5: Comparison of Coarse to Fine Aggregates for Selected Study Plants 


\section{LP \\ I.}

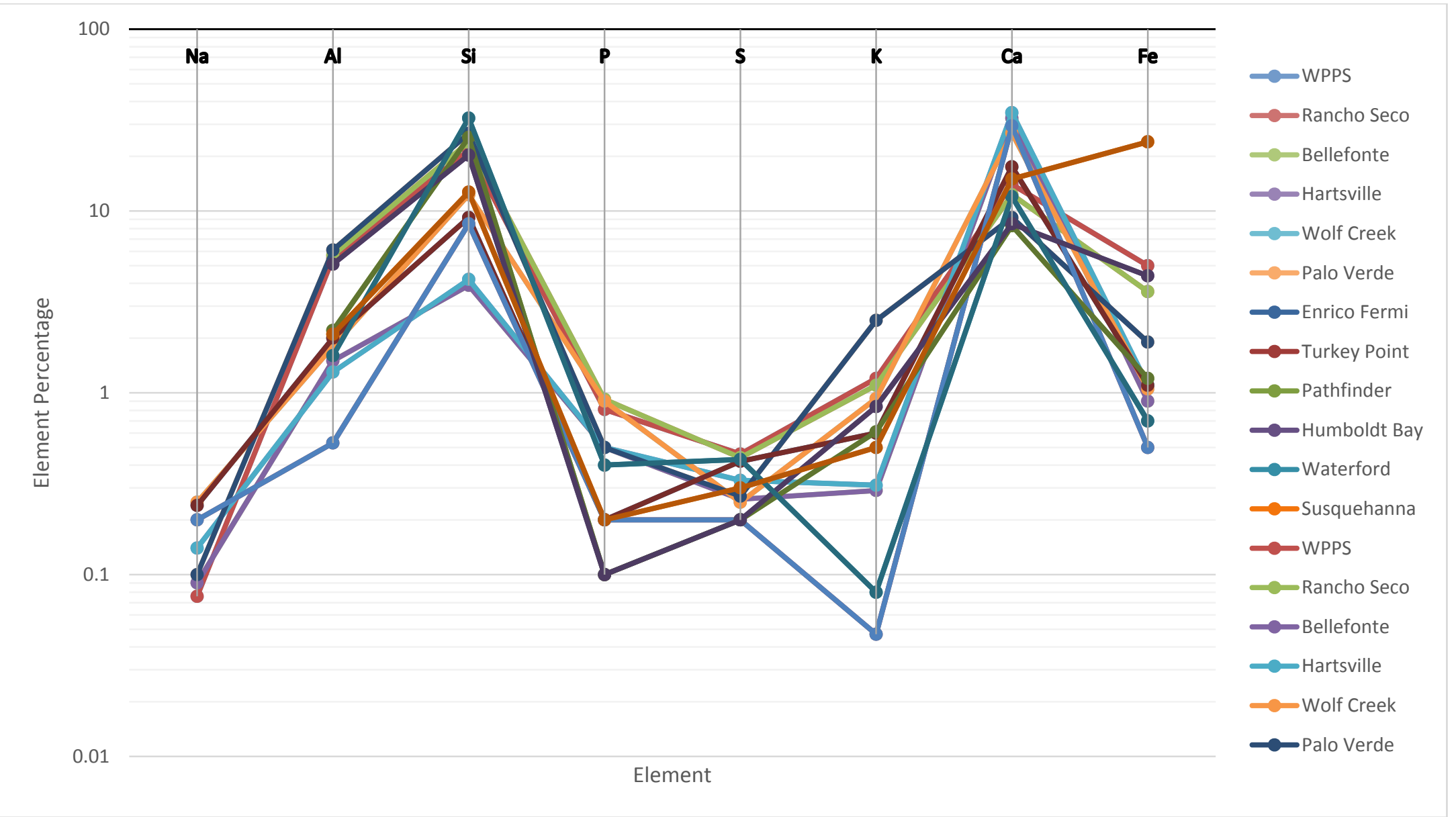

Figure 6-6: Comparison of Concrete for Selected Study Plants 


\section{LPP I.}

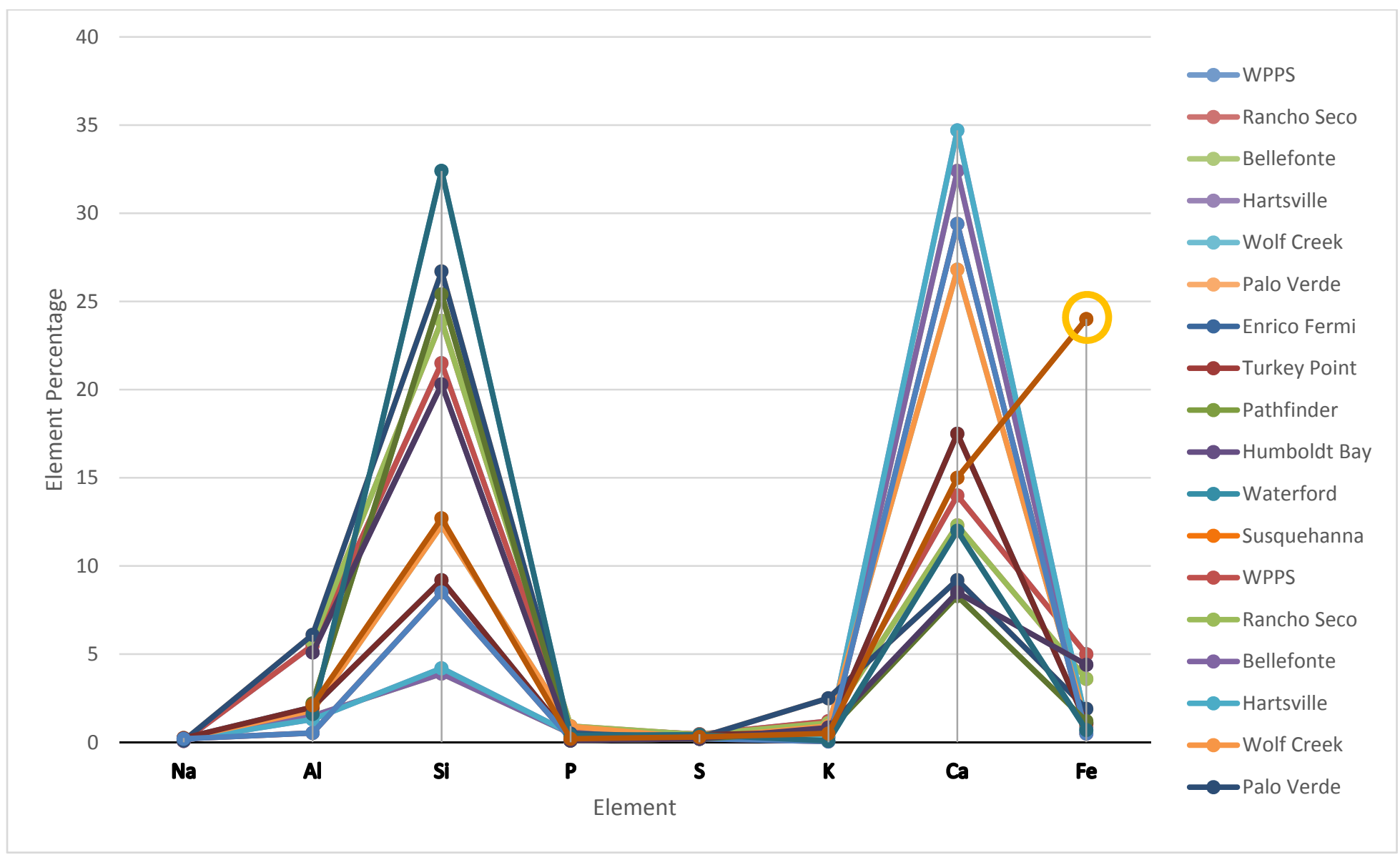

Figure 6-7: Comparison of Concrete for Selected Study Plants

\section{Heavy Aggregate}




\section{LPP \\ I.}

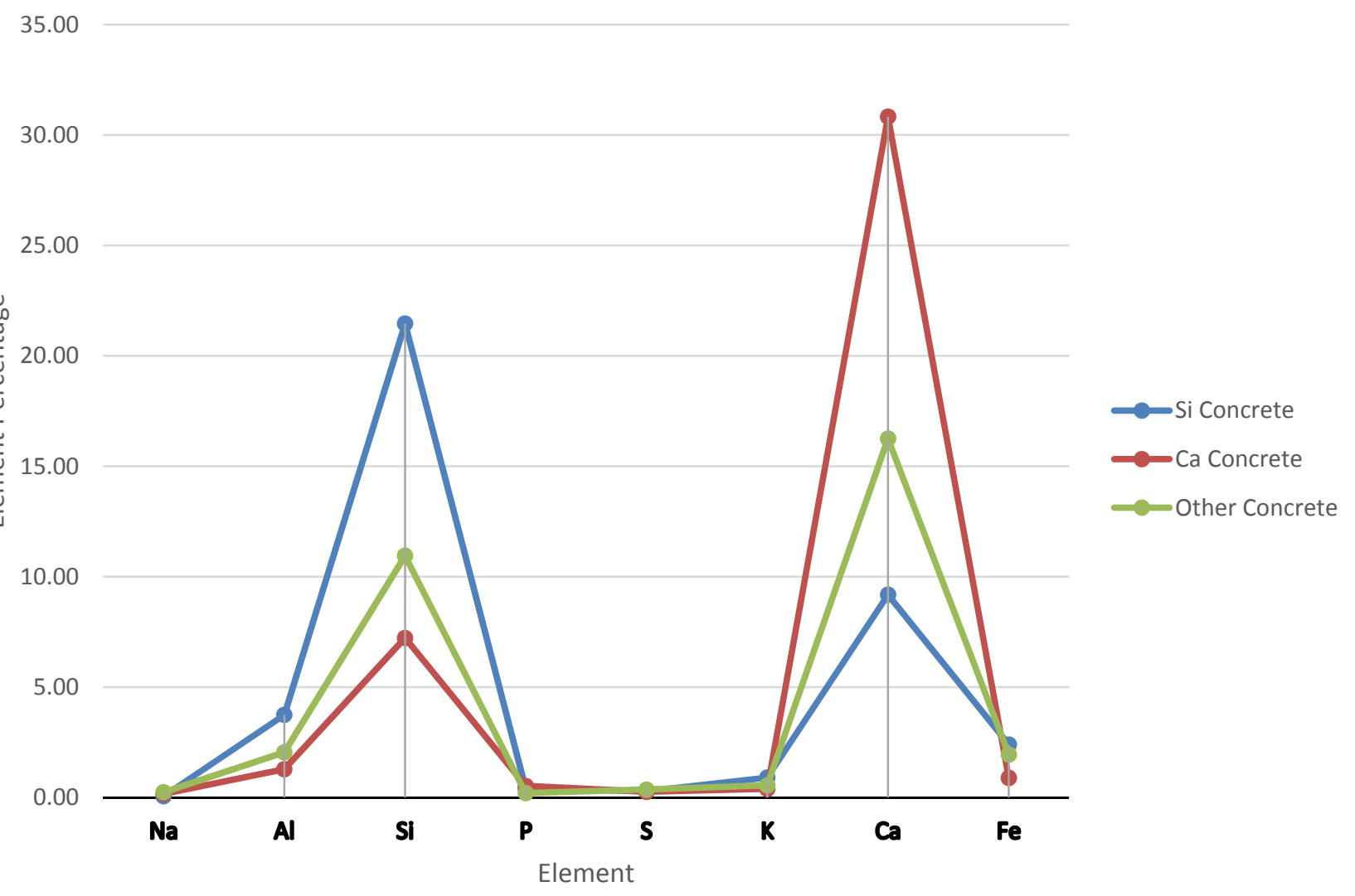

Figure 6-8: Average Element Values for Selected Concrete Types 


\section{SHIELD WALL REQUIREMENTS}

An assessment is performed to define the important requirements of the biological shield wall (BSW) concrete (additionally referenced as reactor cavity concrete, reactor shield concrete, and biological shield concrete). This assessment includes shielding, transferring load to the rebar, and reacting normal and accident loads from the reactor vessel support. Concrete compressive and shear strength will be required to perform these functions. These will be considered to better understand the impact of these functional requirements on any degradation that could occur through radiation damage. This will enable any potential degradation due to radiation to be evaluated in the context of what the structure needs to do.

\subsection{Biological Shield Wall PWR}

The biological shield wall in a PWR performs a number of functions, including providing an integral structure inside the Containment that is integrated into the reactor refuel cavity as a load path to the foundation and can provide support of the reactor pressure vessel for some plants (see Attachment B). The biological shield wall provides for radiation shielding of the reactor pressure vessel and an impingement shield for certain LOCA pipe breaks.

The structure requires strength to support loading from the refuel cavity and support of the reactor pressure vessel. This loading is primarily a gravity based loading which subjects the concrete to direct compression. The shield wall structures are typically relatively massive in thickness (typically 6 to $8 \mathrm{ft}$.), and as a result, stresses from seismic induced inertia or cavity pressurization as a result of LOCA breaks within the cavity are relatively low in stress magnitude.

\subsubsection{Westinghouse NSSS Designs}

As reported in WCAP-14422 [36], four types of RPV supports are used, Type I, II, III, and IV. These are depicted in Figures 7-1 through 7-4 respectively. An evaluation of the RPV support associated with the biological shield wall is outlined in Attachment B.

The Type 1 support configuration, Figure 7-1 uses a shoe arrangement under each RPV nozzle, and was used at 34 US fleet plants (Att. B). The location of the attachment to the concrete, Figure 7-5 (for sample plants reviewed) is typically above the reactor core centerline. This shoe arrangement relies on fins and air cooling to reduce RPV loop temperature to within acceptable limits prior to attachment at the 


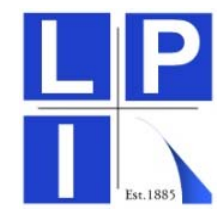

concrete. As a result, this arrangement uses a "higher" shim height, with a resulting larger distance from the nozzle centerline to the bottom of the shim - a longer " $L$ " in Figure 7-1) than other designs. As a result for these plants the attachment point to the concrete is closer to the reactor core centerline than for some other designs, subjecting this region to higher flux levels than other designs.

The Type II configuration shown in Figure 7-2, was used at only two US units (Peach Bottom [36]) and does not rely on the biological shield wall for support, and as such performs only a function of integral structural support for the refuel cavity and would be subjected to self-excitation seismic inertia loading and LOCA break pressurization effects.

The Type III configuration shown in Figure 7-3, was used at four US units (Diablo Canyon and Indian Point [36]). It uses component cooling water to dissipate reactor coolant loop piping temperatures prior to attachment to the biological shield wall concrete. As a result, the support shim height "L" (Figure 7-3) is relatively short, increasing the height between the reactor core centerline and the support attachment point.

The Type IV configuration shown in Figure 7-4, was used at seven US units (designed by the Architect Engineer S\&W at the time), and incorporates a neutron shield tank around the RPV. The RPV support shoes are mounted on the neutron shield tank. Loadings from the RPV are transferred through the shoe to the shield tank to the reinforced concrete structures. As a result, the concrete is more effectively shielded from radiation compared to other designs.

\subsubsection{B\&W NSSS Designs}

The B\&W RPV support design is through a skirt to a concrete pedestal at the base of the vessel (similar to the vessel design used on BWRs). As such the biological shield wall is not required to provide support of the RPV.

\subsubsection{CE NSSS Designs}

As outlined in Attachment B, RPV support design to the biological shield wall differs dependent on individual plants. Some of the designs utilized a column arrangement and some designs utilized a vessel shoe design with load to the biological shield wall. 


\subsubsection{Plant Survey Dimensions for RPV Shoe Designs}

Of the differing RPV support designs, the design configuration that utilizes a "support shoe" under the RPV nozzles has the greatest potential for the concrete to experience the highest level of fluence at the support point. The distance above the reactor core and depth of anchorage into the concrete will effectively result in this attachment point seeing lower fluence than the reactor cavity wall at the core centerline and at the surface of the concrete.

As shown in Figure 7-5, dimensions are marked to enable an individual plant to gather required dimensions to help assess actual fluence levels at the embedment point.

A survey of five individual plants that utilized the shoe design identified a wide variation in the positioning of the shoe anchorage. The "least" conservative of these plants had a distance between the support anchorage and the reactor vessel - "L3" in Figure 7-5 - of 10" (with the cavity clearance "L1" of 6") and an" $L 4$ " dimension of 12 ". Of the surveyed plants, the variation of the height of the vessel support above the core center line varied significantly.

\subsection{Biological Shield Wall BWR}

The biological shield wall in a BWR primarily performs a function associated with radiation shielding of the reactor pressure vessel and an impingement shield for certain LOCA pipe breaks. Pipe breaks within the annulus between the reactor pressure vessel and the biological shield wall would also result in pressurization of the biological shield wall.

A typical biological shield wall for a BWR is shown in Figure 7-6 for a Mark I design and in Figure 7-7 for a Mark III design. It is evident that for the BWR design the biological shield wall is significantly thinner than for typical PWR designs. This is a result of the wall being required to provide radiation shielding only, and is not an integral structural support for the inner containment structure, as for a PWR. As outlined in Attachment $B$, the biological shield wall is not relied upon to provide structural support of the RPV. As a result, seismic stresses in the wall from self-excitation under seismic loads, or cavity pressurization as a result of LOCA breaks within the cavity may result in higher stresses, than for thicker walled PWR biological shield concrete. 

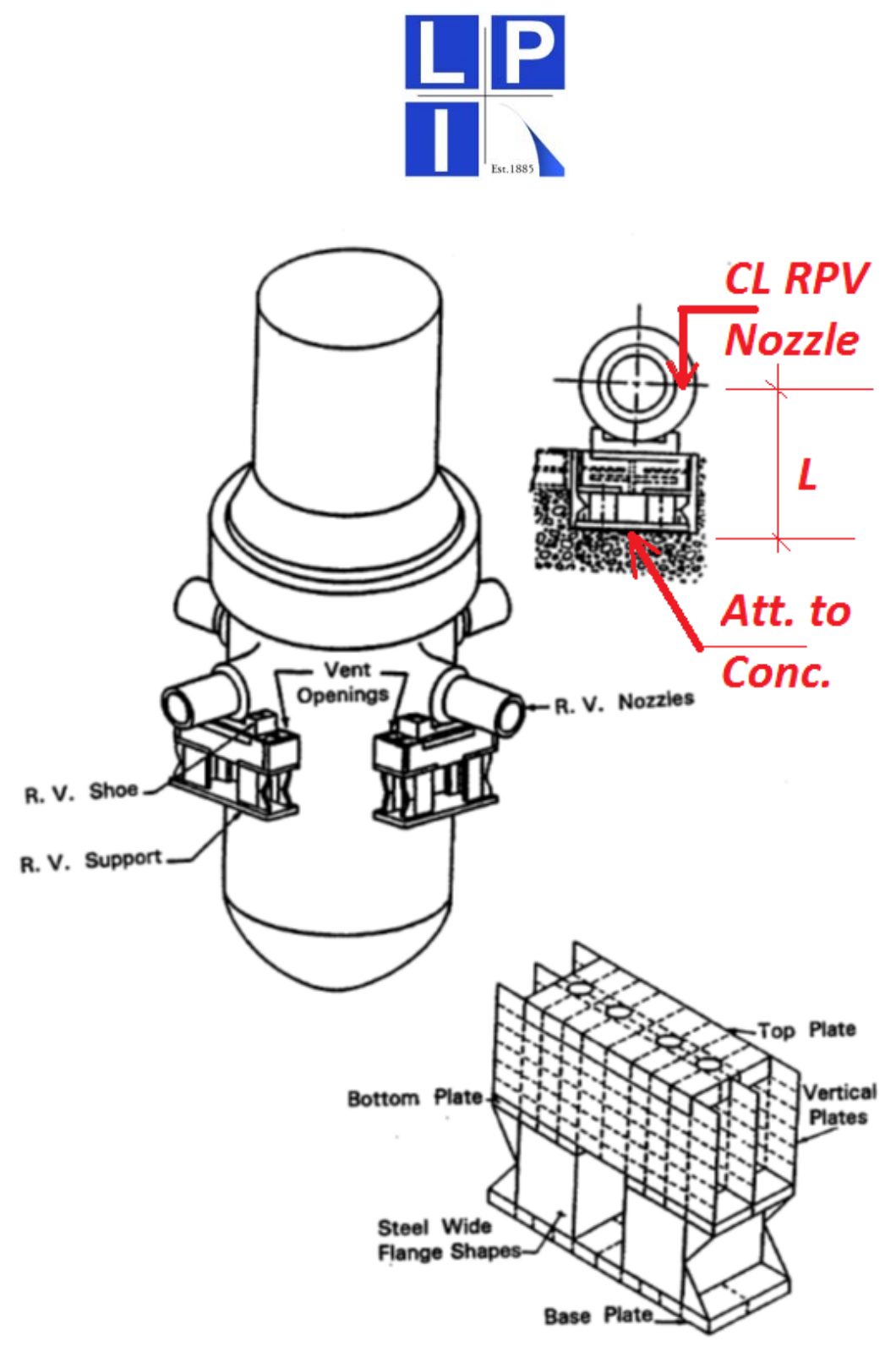

Figure 7-1: W RPV Support Configuration Type I [44] 


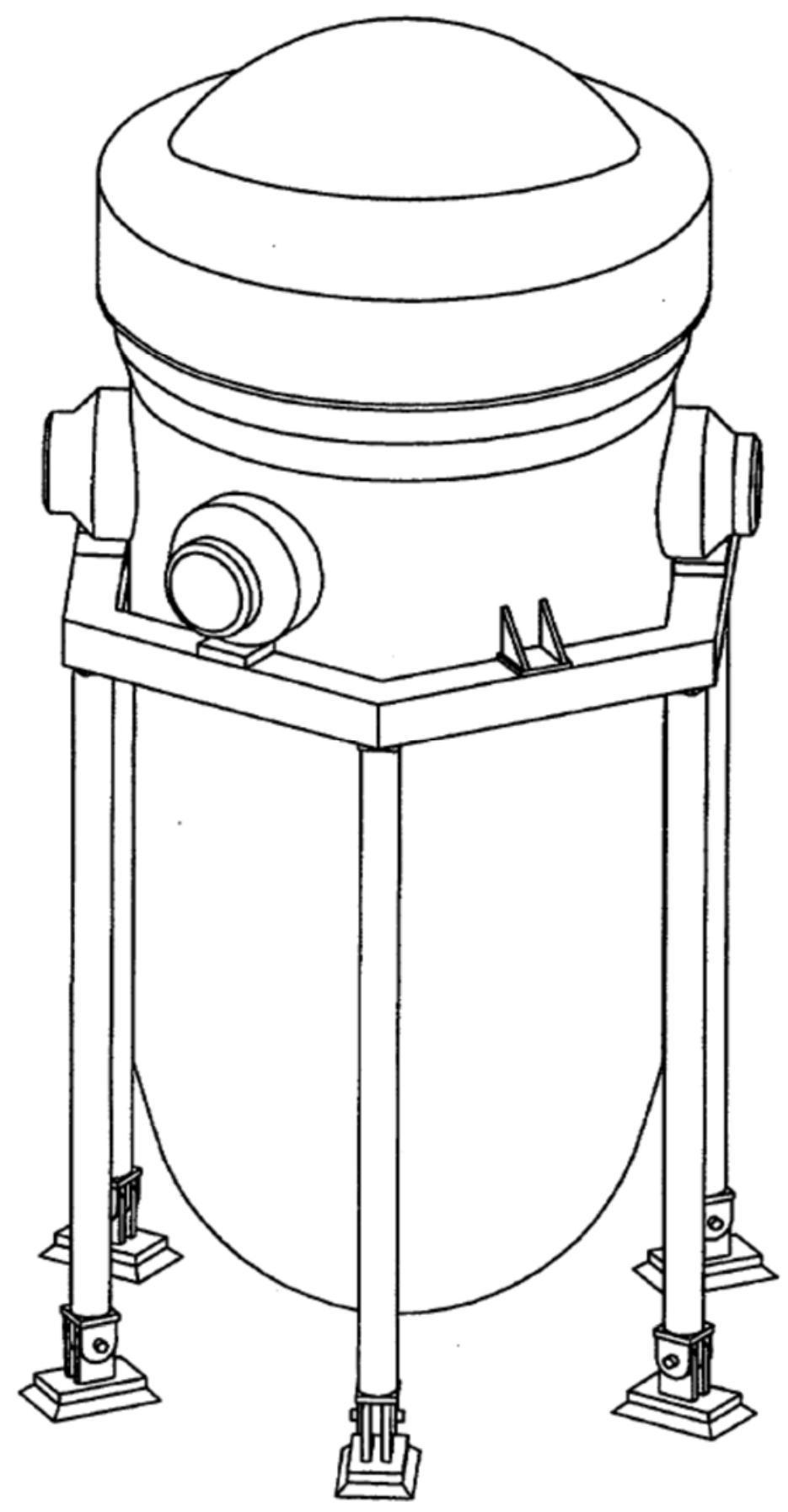

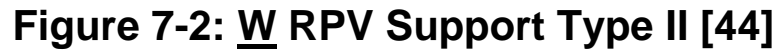




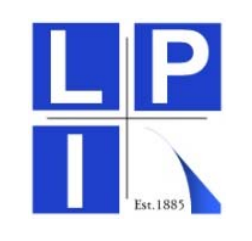

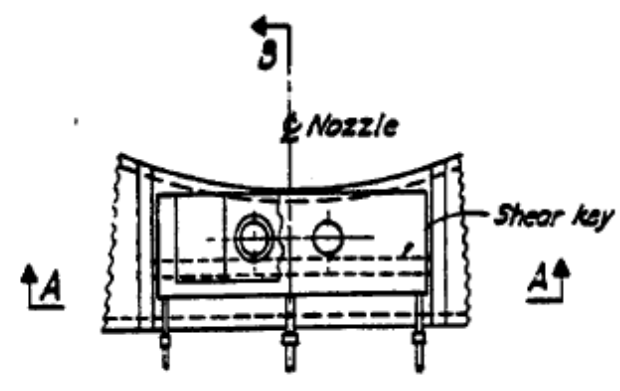

Bj
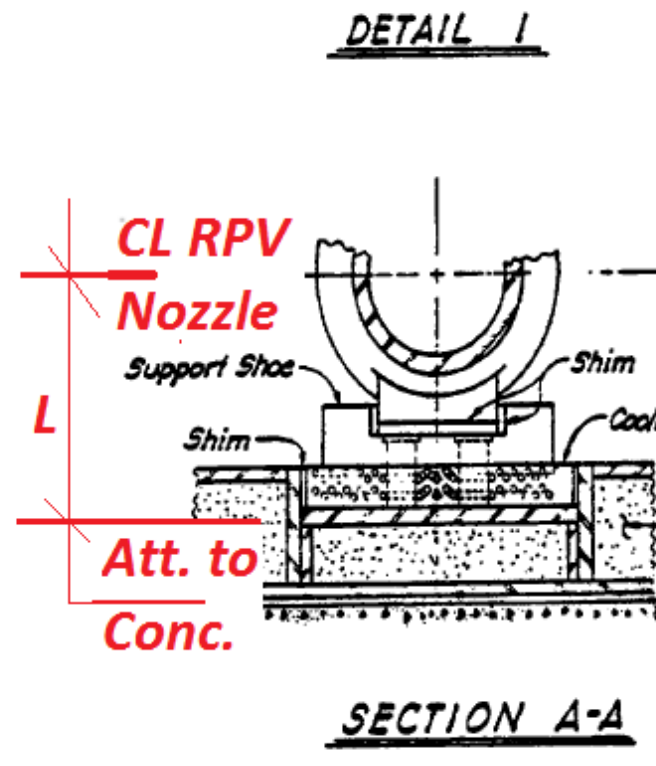

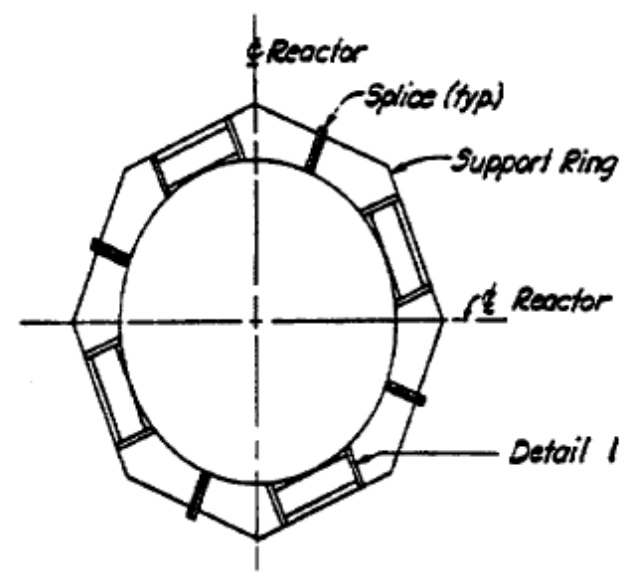

KEY PLAN

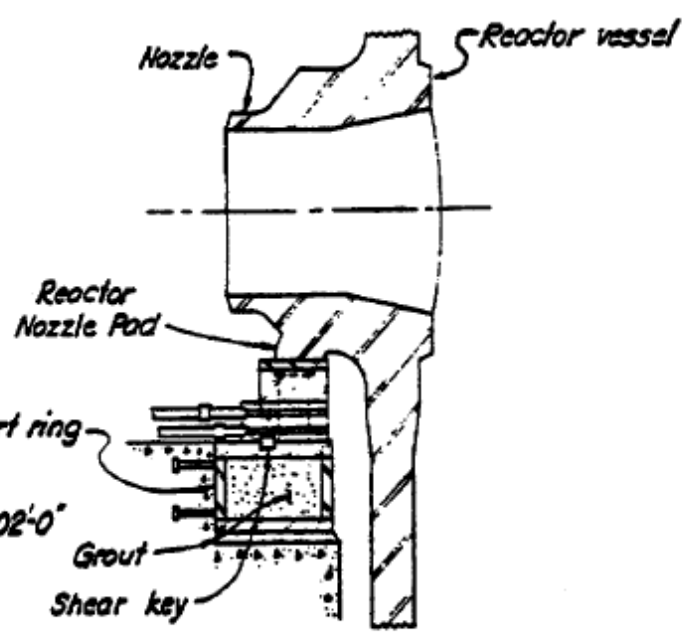

SECTION B-B

Figure 7-3: ㅌ RPV Support Type III [44] 

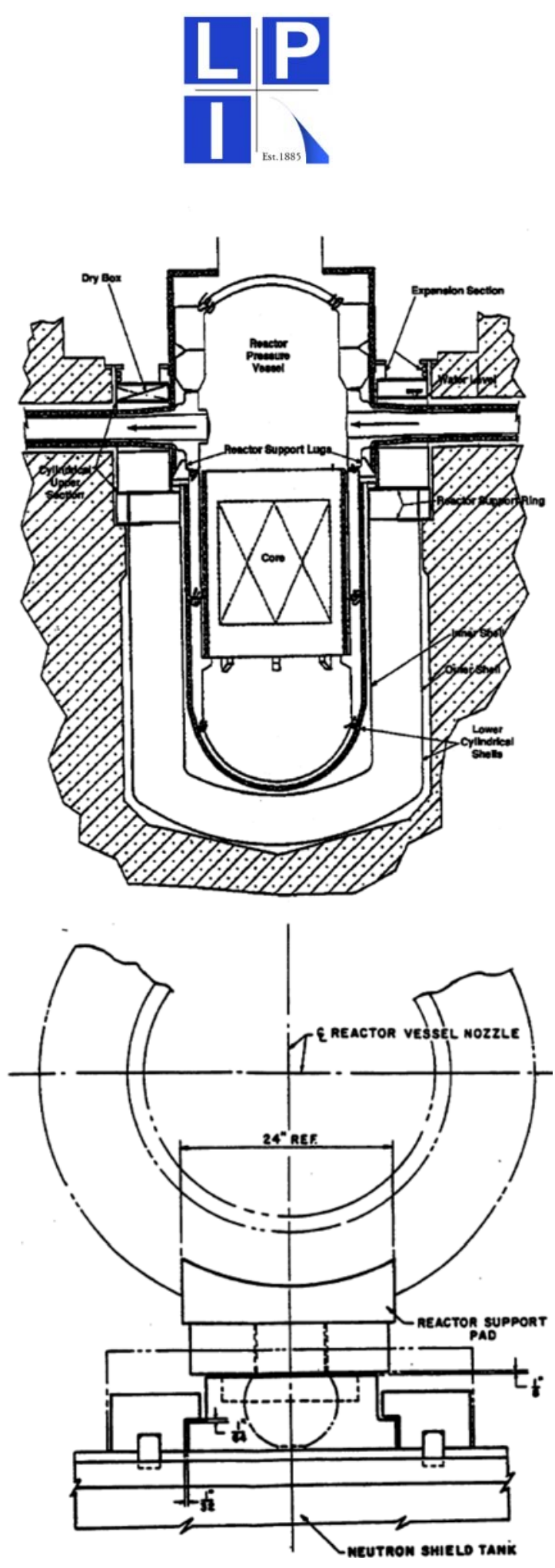

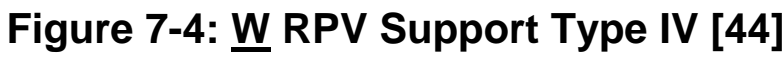

Report No. A13276-R-001

Revision 0 


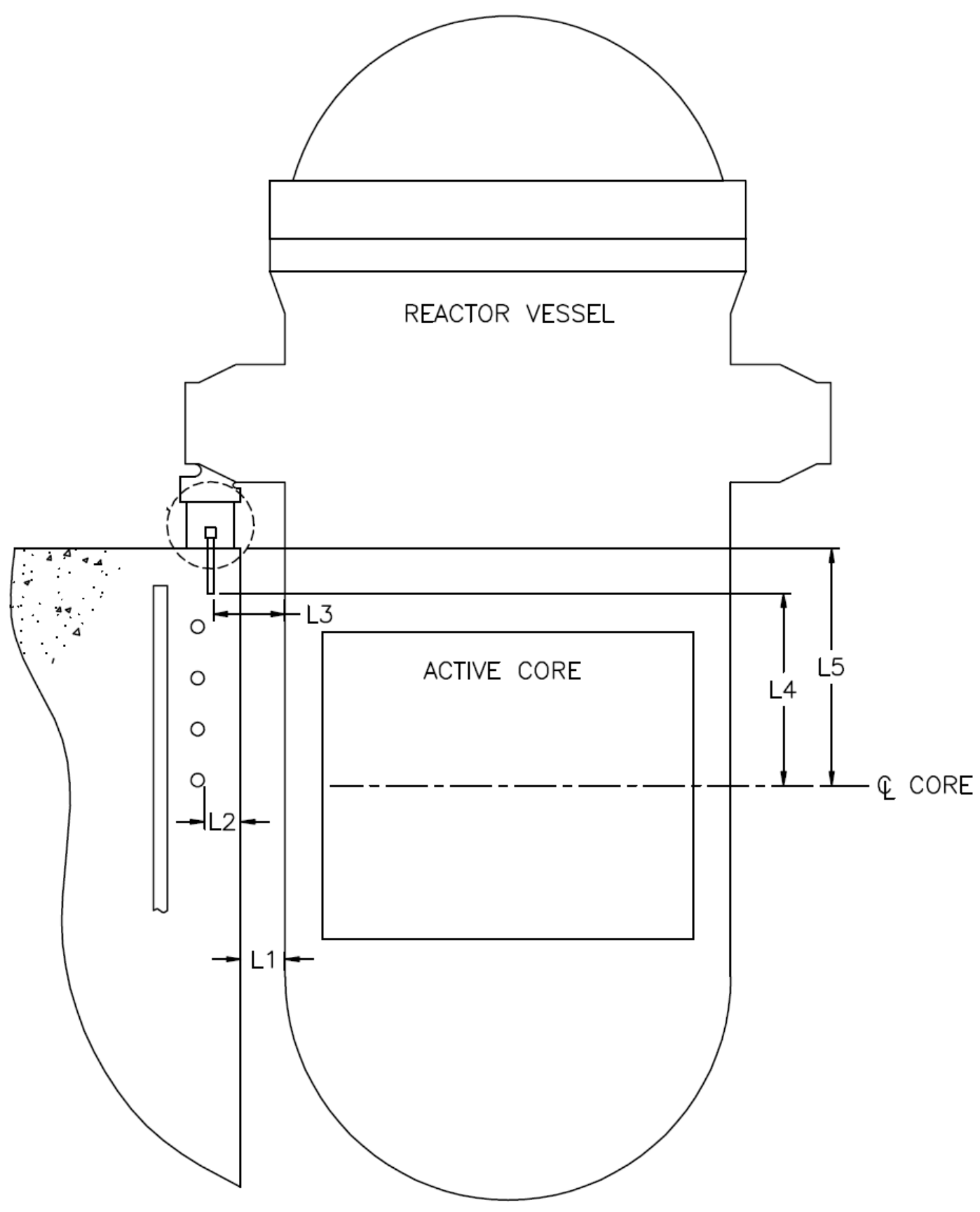

Figure 7-5: Dimensional Configuration for Plant Specific Survey 


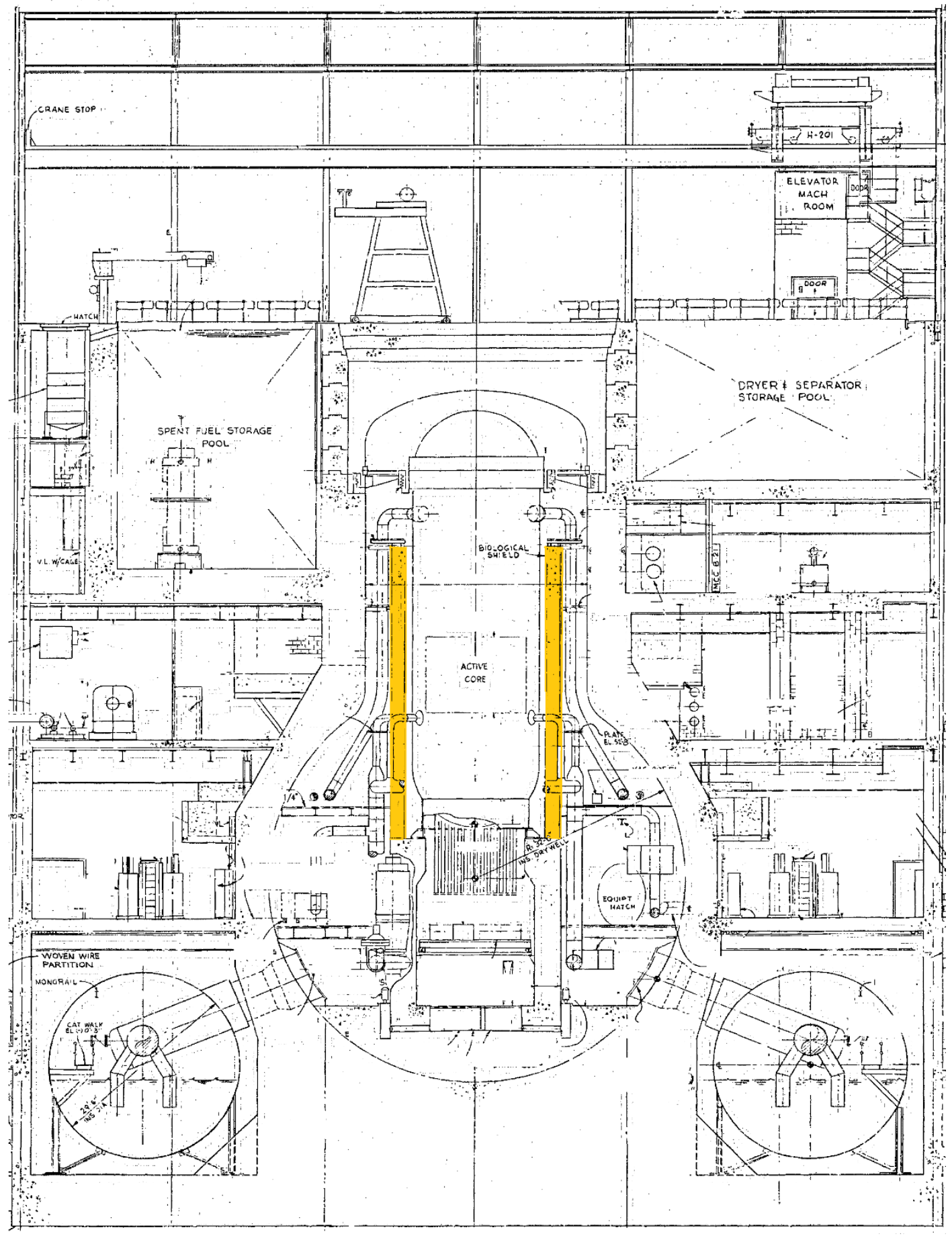

Figure 7-6: Typical Biological Shield Wall for BWR Mark I Design 


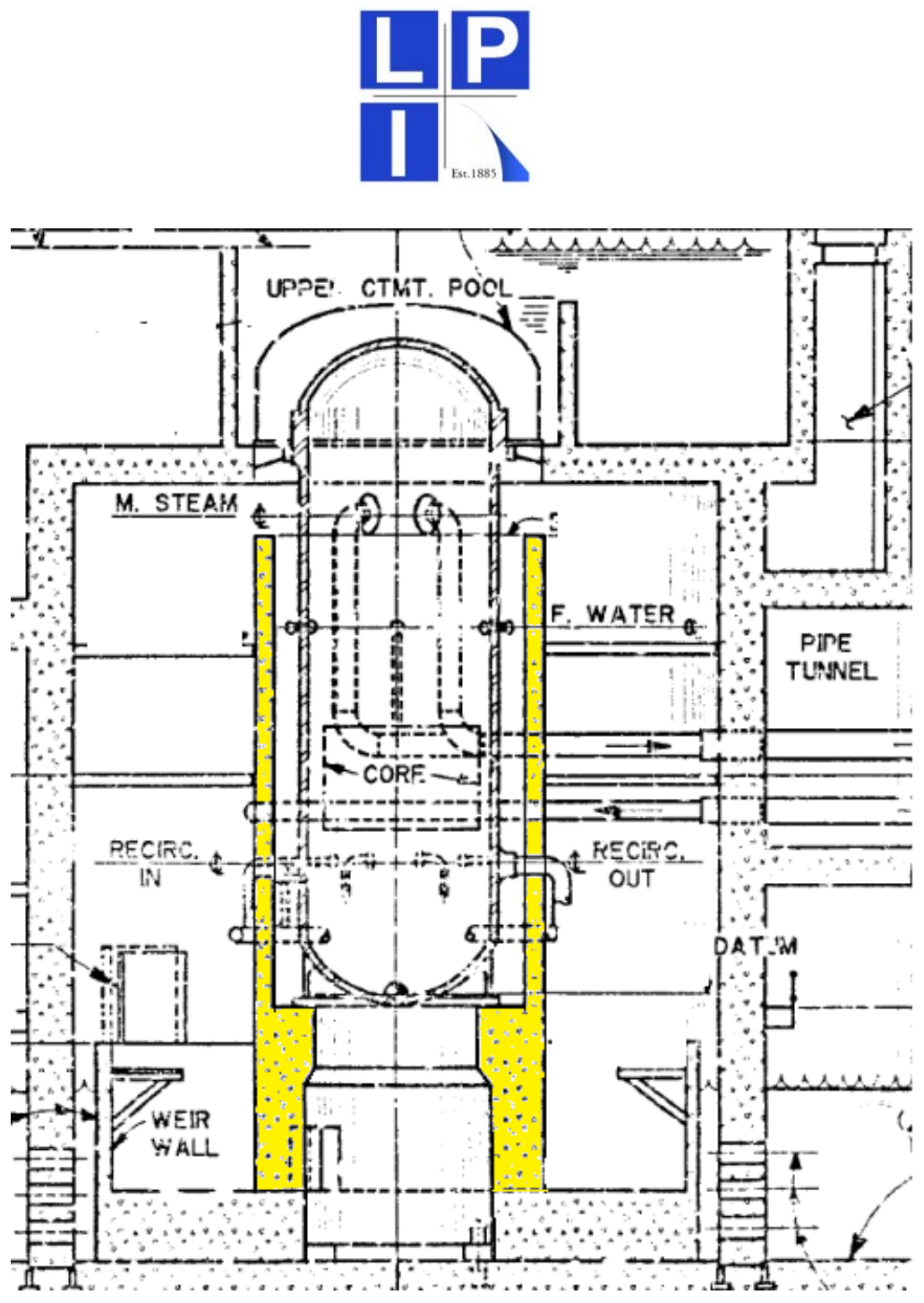

Figure 7-7: Typical Biological Shield Wall for BWR Mark III Design

Report No. A13276-R-001

Revision 0 


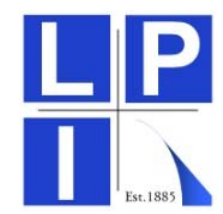

\section{EXPECTED CONCRETE CONDITION AT 80 YEARS}

Based on the evaluations contained in this report, the following statements can be made about the condition of the concrete in the biological shield wall:

- The maximum neutron fluence expected in nuclear plant reactor cavity/shield wall concrete is approximately $6.1 \mathrm{E}+19 \mathrm{n} / \mathrm{cm}^{2}$ with energy greater than $0.1 \mathrm{MeV}$.

- Currently available data that is considered to be reliable and well documented shows that compressive strength will not change up to the maximum value tested, which is $2.3 \mathrm{E}+19 \mathrm{n} / \mathrm{cm}^{2}$ with energy greater than $0.1 \mathrm{MeV}$.

- It is likely that additional testing will show that concrete strength will not degrade with higher fluence.

- The neutron fluence attenuates in the concrete. The fluence will be attenuated an order of magnitude in approximately 5 inches. For the limiting plant with a peak fluence of $6.1 \mathrm{E}+19 \mathrm{n} / \mathrm{cm}^{2}$ with energy greater than $0.1 \mathrm{MeV}$, the fluence will attenuate to $2.3 \mathrm{E}+19 \mathrm{n} / \mathrm{cm}^{2}$ in approximately the first 2 inches of concrete.

- Reliable data for exposure to gamma radiation is not available. The data that is available indicates that a threshold value of approximately $2.0 \mathrm{E}+10$ rads would be acceptable. This exceeds the maximum gamma dose of $1.23 \mathrm{E}+10$ rads that is expected at 80 years of operation.

- For those reactor designs that rely on the biological shield wall for support, the location of reactor vessel support structures and rebar critical to supporting the vessel is generally not within the region of highest fluence. For the plants reviewed, it is always above the centerline of the core and for many plant designs, it is above the top of the core. Above the RPV beltline region the fluence drops off. The support structures that are deeper in the concrete also will not experience peak fluence.

- Major structural rebar is not expected to be within the first 2 to 3 inches of the biological shield wall, and much of it will be much deeper.

- The increase in temperature of the concrete due to neutron and gamma exposure has been calculated and is small. The increase calculated leaves that concrete well below the accepted limits for long term concrete exposure.

- The function of the biological shield wall for all reactor designs is to provide shielding. For certain PWR designs, the biological shield wall provides support of the reactor vessel and is an integral part of the inner containment structure. The 


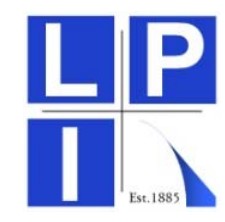

biological shield wall needs to be capable of providing deadweight support for applied loads and to withstand the inertial loads and reactor vessel support loads from a seismic event, and to withstand the imposed loads from the reactor vessel during a LOCA.

Based on these conclusions, it appears that none of the required functions of the biological shield wall will be compromised by radiation-induced material changes or radiation induced heat-up of the concrete for an operating period of 80 years.

Additional work, much of it planned or being considered, is expected to further support and validate this conclusion. 


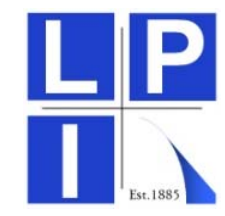

\section{RECOMMENDATIONS}

It is recommended that the following topics be considered in order to enhance the clarity and confidence in the positions regarding the concrete in nuclear power plants. Many of these topics may already be incorporated into ongoing or planned projects.

- Neutron Energy Levels of $>0.1 \mathrm{MeV}$ - The energy levels of neutrons considered are based on the characteristics of the material being irradiated. When neutrons collide within the material, they need sufficient energy to displace an atom from its lattice. For this reason, low energy neutrons are commonly neglected. For carbon steel materials used in reactor vessels, as an example, the neutron inclusion energy has been determined to be neutrons with energy greater than $1 \mathrm{MeV}$. For concrete, many research teams have used an energy inclusion level of greater than $0.1 \mathrm{MeV}$.

A technical basis for selection of $0.1 \mathrm{MeV}$ is not well documented in the literature. It would be useful to identify the basis for a neutron energy level based on the material properties of concrete. The development of this basis would be useful.

- Additional Neutron Exposure Testing - Tests to $2.3 \mathrm{E}+19 \mathrm{n} / \mathrm{cm}^{2}$ have shown no reduction in concrete strength. Tests to higher fluence would be helpful to define the margin available. Knowing the fluence at which a reduction in compressive strength would occur could be helpful.

- Varying Concrete Composition - Concrete composition variation will mostly be due to differences in the aggregate and somewhat due to differences in concrete mix. The cement that has been used in current commercial nuclear plants is relatively consistent across the plants in the United States. Some plants have included additives. The aggregate vary based on the region of the country. Tests of commonly used aggregates should be considered so that the effect of neutrons on just the aggregate could be determined.

- Gamma Testing - The effect of gamma radiation on concrete is not well documented. Gamma radiation can cause displacement per atom damage rates comparable to neutrons, but it is generally considered to be less important than neutron exposure. The testing that has been performed to determine an acceptable gamma dose has been generally supportive of the acceptability of concrete, but has been inconclusive. Additional work is required to document the behavior of concrete exposed to gamma radiation. Levels of gamma exposure that will reduce the compressive strength of concrete should be developed. 
- Physics of Degradation -- In order to assure a complete understanding of the potential of degradation of concrete over the period of 80 years or more, it is important to enhance the ability to correlate the relationship between the actual (in-plant) concrete behavior and the fundamental radiation damage mechanisms that occur. This is important for the combined effects of neutron and gamma exposure. Given the variability in plant-to-plant composition of the cement, the aggregate, and additives as well as in differences in "processing" (water content, sand content, etc.), it is important that the fundamental relationships between these variables and the resulting radiation damage processes be known. With a "baseline" fundamental knowledge that relates key parameters to behavior, tests can be more reliably designed and operating conditions more accurately assessed. 


\section{LP \\ II}

\section{REFERENCES}

1. Fujiwara K, et al "Experimental Study of the Effect of Radiation Exposure to Concrete", $20^{\text {th }}$ Int. Conf. on Structural Mechanics in Reactor Technology (SMIRT 20), Div. 1, Paper 1891.

2. Kontani, O., et. al., "Irradiation Effects on Concrete", International Symposium on the Aging Management and Maintenance of Nuclear Power Plants, 2010, pp 173182.

3. US NRC Regulatory Guide 1.99, Rev. 1, "Effects of Residual Elements on Radiation Damage to Reactor Vessel Materials", April 1977

4. US NRC Regulatory Guide 1.99, Rev. 2, "Radiation Embrittlement of Reactor Vessel Materials", May 1988

5. TransWare Enterprises (TwE) Report No. TWE-LPI1-001-R-001, Rev. 0 "An Evaluation of Neutron, Gamma, and Temperature Profiles in a Three Loop PWR Biological Shield", February, 2013

6. Remec, I., "Radiation Environment in Biological Shields of Nuclear Power Plants", Oak Ridge National Laboratory (ORNL), March 22, 2013

7. EPRI NP-152, "Study of Radiation Damage to Structural Components in Nuclear Reactors", January 1976

8. Randall, P, "Basis for Revision 2 of the US Nuclear Regulatory Commission's Regulatory Guide 1.99" "Radiation Embrittlement of Nuclear Reactor Pressure Vessel Steels: An International Review (second Volume)",ASTM , STP 909, 1986 pp 149-162

9. Remec, I "Study of the Neutron Flux and Dpa Attenuation in the Reactor PressureVessel Wall”, ORNL/NRC/LTR-99/5, June 1999.

10. Asgari, M., Williams, M. L., and Kam, F .B. K., "Determination of the Neutron and Gamma Flux Distribution in the Pressure Vessel and Cavity of a Boiling Water Reactor", NUREG/CR-5449, ORNL/TM-11350, June 1990.

11. X-5 Monte Carlo Team, "MCNP - A General Monte Carlo N-Particle Transport Code , Version 5", Los Alamos National Laboratory, Document LA-UR-03-1987

12. Williams, R, C. Gesh, R. Pagh "Compendium of Material Composition Data for Radiation transport Modeling”, PNNL-15870, April 2006.

13. M. Wieser and M. Berglund "Atomic Weights of the Elements 2007," IUPAC 2007 Pure Appl. Chem., 81, no 11, 2009.

14. N. Horelik, B. Herman, B. Forget, and K. Smith, Benchmark for Evaluation and Validation of Reactor Simulations (BEAVRS), v1.0.1. Proc. Int. Conf. Mathematics and Computational Methods Applied to Nuc. Sci. \& Eng., Sun Valley, Idaho, 2013. 
15. NIST Database,

http://physics.nist.gov/PhysRefData/XrayMassCoef/ComTab/concrete.html.

16. $\mathrm{ACl}$ 318, "Building Code Requirements for Structural Concrete", American Concrete Institute.

17. ACl 349, "Code Requirements for Nuclear Safety Related Concrete Structures, American Concrete Institute, Reported by ACI Committee 349.

18. "Effects of Radiation on Concrete: A Literature Survey and Path Forward", EPRI Report 1025584, May, 2012.

19. Hilsdorf, H, J. Kropp, H. Kock, "The Effects of Nuclear Radiation on the Mechanical Properties of Concrete", American Concrete Institute Report SP-55-10, 1978.

20. Duborvskii, V., Ibragimov, S., Kulakovskii, M., Ladygin, A., and Pergamenshchik, B., "Radiation Damage in Ordinary Concrete", Atomnaya Energiya, Vol. 23, No. 4, pp 310-316, 1966.

21. Sommers, J., "Gamma Radiation Damage of Structural Concrete Immersed in Water", Health Physics, Pergamon Press, Vol. 16, pp 503-508, 1969.

22. Gray, B., "The Effect of Reactor Radiation on Cements and Concrete', Commission of the European Communities, Luxembourg, pp 17-39, 1972.

23. Soo, P., and Milian, M., "the Effect of Gamma Radiation on the Strength of Portland Cement Mortars," Journal of Materials Science Letters, 20, 2001.

24. Sopko, V., Trtik, K., and Vodak, F., "Influence of Gamma Irradiation on Concrete Strength”, Acta Polytechnica, Vol. 44, No. 1, 2004.

25. Kontani, O., Sawada, S., Maruyama, I., Takizawa, M., and Sato, O., "Evaluation of Irradiation Effects on Concrete Structure - Gamma Ray Irradiation Tests on Cement Paste", Proceedings of the ASME 2013 Power Conference, POWER 2013-98099, 2013.

26. Evan, J., "Long-Lived Activation Products in Reactor Materials", NUREG CR-3474, 1984.

27. Review of selected licensee reactor specifications, selected for type (PWR/BWR), vintage (early or more recent), and geographic diversity.

28. Ren, W., Naus, D., Oland, B., "Implementation Plan and Initial Development of Nuclear Concrete Materials Database for Light Water Reactor Sustainability Program", ORNL/TM-2010/177.

29. Florida Power Corporation, "Crystal River Unit 3 Nuclear Generating Plant, Reactor Building Dome Delamination”, Final Report, December, 1976.

30. Naus, D. and Oland, C., "An Investigation of Tendon Sheathing Filler Migration into Concrete”, NUREG/CR-6598, ORNL/TM-13554, March, 1998. 


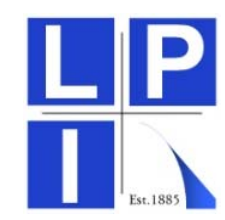

31. Winter, N "Understanding Cement - An introduction to cement production, cement hydration and deleterious processes in concrete" printed by WHD Microanalysis Consultants, Ltd.'

32. Kaplan, M. F., Concrete Radiation Shielding: Nuclear Physics, Concrete Properties, Design and Construction. John Wiley \& Sons, Inc. New York. 1989.

33. Langer, W. "Aggregates of the Conterminous United States", US Geological Survey Bulletin, No 1594.

34. American Concrete Institute Standards associated with concrete mix:

a. ACl-301, "Specifications for Structural Concrete"

b. ACl-613 "ACl Standard Recommended Practice for the Design of Concrete Mixes"

35. ASTM Standards associated with concrete:

a. ASTM C-33, Standard Specification for Concrete Aggregates.

b. ASTM C-39, Standard Test Method for Compressive Strength of Cylindrical Concrete Specimens.

c. ASTM C-40, Standard Test Method for Organic Impurities in Fine Aggregates for Concrete.

d. ASTM C-94, Standard Specification for Ready-Mixed Concrete.

e. ASTM C-143, Standard Test Method for Slump of Hydraulic-Cement Concrete.

f. ASTM C-150, Standard Specification for Portland Cement.

g. ASTM C-231, Standard Test Method for Air Content of Freshly Mixed Concrete by the Pressure Method.

h. ASTM C-260, Standard Specification for Air-Entraining Admixtures for Concrete.

i. ASTM C494, "Standard Specification for Chemical Admixtures for Concrete".

j. ASTM C-618, Standard Specification for Coal Fly Ash and Raw or Calcined Natural Pozzolan for Use in Concrete.

k. ASTM C-637, Standard Specification for Aggregates for Radiation Shielding Concrete.

36. Westinghouse Energy Systems WCAP-14422, Rev. 2-A "Licensing Renewal Evaluation: Aging Management for Reactor Coolant System Supports". 


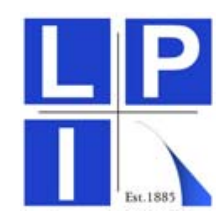

Attachment A

\section{Reactor Vessel Wall Neutron Fluence Values for PWR and BWR Reactors}




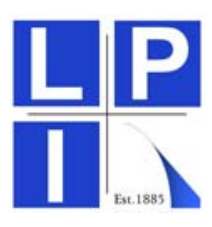

\section{A1.0 DESCRIPTION}

Reactor vessel neutron fluence values were studied for Pressurized Water Reactor (PWR) and Boiling Water Reactor (BWR) power plants in the United States. Selected neutron fluence values for each power plant site were based on the Effective Full Power Years (EFPY) at the End of License (EOL) period. The EOL neutron fluence values were taken from plant documents, extracted from the NRC ADAMS online database. All documents are listed in the Reference section below.

Calculations are developed considering an operating life of 80 years. An average capacity factor (CF) of $92 \%$ was applied for the life of the plant. This value is considered to envelope a typical reactors performance for a top performing nuclear plant, and would likely be considered as conservative over the life of a typical reactor. The final effective full power years (EFPY) would then be 80 years $\times 92 \%$ $\mathrm{CF}=73.6 \mathrm{EFPY}$.

Based on the provided EFPY value calculated for a plant at the time of the report, neutron fluences through the reactor pressure vessel (RPV) wall are reported at four locations through the thickness: The vessel inside surface (0T), 1/4 of the way through the vessel wall (1/4T), 3/4 of the way through the vessel wall (3/4T) and the outside wall surface (1T), as shown in Figure A-1-1 below. Neutron fluence values are taken in the RPV beltline or intermediate region.

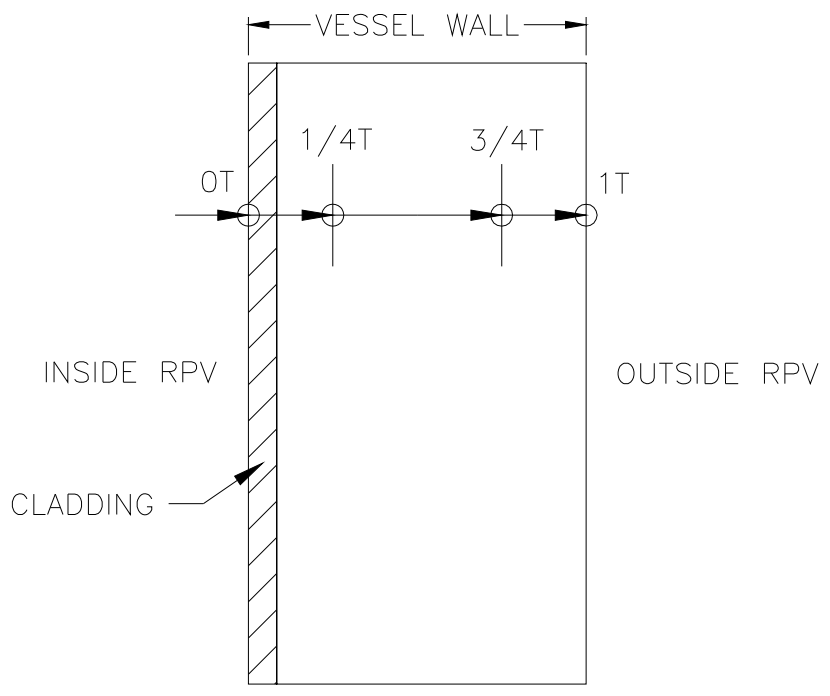

Figure A-1-1. Vessel Wall Neutron Fluence Locations 


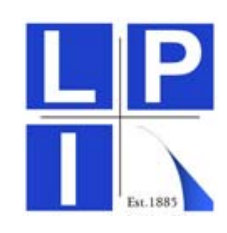

Depending on available information, vessel wall fluence values at the $0 \mathrm{~T}, 1 / 4 \mathrm{~T}, 3 / 4 \mathrm{~T}$, and $1 \mathrm{~T}$ locations along with the vessel wall thickness are taken from plant documentation and reported in Table A-1 below. For vessel wall fluence values that were not given in plant documentation, values were iterated according to NRC Regulatory Guide 1.99 [A99] ${ }^{4}$ using Equation A1 below.

$$
f=f_{\text {surf }}\left(e^{-0.33 x}\right)
$$

Where:

$f=$ neutron fluence $\left(10^{19} \mathrm{n} / \mathrm{cm}^{2}\right)$ at the inner (wetted) surface ${ }^{5}$.

$x=$ depth into vessel wall (inches) measured from vessel inner (wetted) surface.

For 80 years with $92 \% \mathrm{CF}$, the vessel outside surface (1T) neutron fluence values are calculated using Equation A2 below.

$$
f_{1 T @ C F}=\left(\frac{\text { CFyears }}{E F P Y}\right) \times f_{1 T}
$$

The vessel outside surface (1T) neutron fluence values for 80 years with $92 \%$ CF are reported in Table A-1 and displayed in Figure A-4. for PWR power plants and Figure A-5. for BWR power plants. In Figure A-4, the vessel wall neutron fluence values are grouped according to the number of loops in the PWR plant system.

\section{A2.0 EXAMPLES}

\section{A2.1 Example 1:}

The process used to calculate the vessel outside surface (1T) neutron fluence for Ginna Station is shown below. First, the EFPY is determined for the EOL period. Then the neutron fluence values at EOL for the $0 \mathrm{~T}, 1 / 4 \mathrm{~T}$, and $3 / 4 \mathrm{~T}$ locations through

${ }^{4}$ Numbers in $[x x]$, refer to references listed in Section A3.0

5 The inner wall typically contains a cladding, with the wetted surface being the inside of the cladding. The provided wall thickness in the reports extracted from Adams, may or may not include the cladding. Ignoring the cladding thickness is considered to be conservative. 


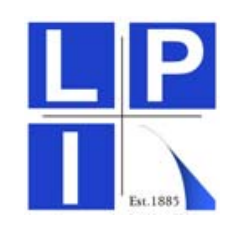

the vessel wall and the vessel wall thickness were found in [A27] as shown in the excerpts in Figure A-2 below.

- The calculated 53 EFPY (end-of-license renewal) neutron fluences $(\mathrm{E}>1.0 \mathrm{MeV})$ at the core midplane for the R. E. Ginna reactor vessel using the Regulatory Guide 1.99, Revision 2 attenuation formula (i.e., Equation $\# 3$ in the guide) are as follows:

Calculated (53 EFPY): $\quad$ Vessel inner radius* $=5.56 \times 10^{19} \mathrm{n} / \mathrm{cm}^{2}$ (Taken from Table 6-2A)

Vessel $1 / 4$ thickness $=3.76 \times 10^{19} \mathrm{n} / \mathrm{cm}^{2}$

Vessel $3 / 4$ thickness $=1.73 \times 10^{19} \mathrm{n} / \mathrm{cm}^{2}$

The R. E. Ginna reactor vessel beltline region minimum thickness is 6.50 inches. Calculation of the 1/4T vessel fluence values at 53 EFPY for the intermediate shell and lower shell forgings and the intermediate shell to lower shell girth weld is shown as follows:

Figure A-2. Excerpts from [A27]

The neutron fluence is calculated for "vessel $1 \mathrm{~T}$ thickness" using Equation A1 as shown below:

$$
f_{1 T}=5.56 \cdot 10^{19}\left(e^{-0.24 \cdot(6.50)}\right)=1.17 \cdot 10^{19} \frac{\mathrm{n}}{\mathrm{cm}^{2}}
$$

The vessel outside surface (1T) neutron fluence for 80 years with $92 \% \mathrm{CF}$ is calculated using Equation A2 as shown below:

$$
f_{1 T @ 80 y r}=\left(\frac{73.6}{53}\right) \times 1.17 \cdot 10^{19}=1.62 \cdot 10^{19} \frac{\mathrm{n}}{\mathrm{cm}^{2}}
$$

\section{A2.2 Example 2:}

The process used to calculate the vessel outside surface (1T) neutron fluence for Catawba Unit 1 is shown below. First, the EFPY is determined for the EOL period. Then the neutron fluence values at EOL for the $0 \mathrm{~T}, 1 / 4 \mathrm{~T}$, and 3/4T locations through the vessel wall and the vessel wall thickness were found in [A60] as shown the excerpt in Figure A-3 below. 
TABLE 1

Summary of the Vessel Surface, 1/4T and 3/4T Fluence Values used for the Gencration of the 34 EFPY Heatup/Cooldown Curves

\begin{tabular}{|c|c|c|c|}
\hline Material & Surface & $1 / 4 \mathrm{~T}$ & $1 / 4 \mathrm{~T}$ \\
\hline Intermediate Shell Forging 05 & $1.98 \times 10^{19}$ & $1.19 \times 10^{19}$ & $4.31 \times 10^{18}$ \\
\hline Lower Shell Forging 04 & $1.98 \times 10^{19}$ & $1.19 \times 10^{19}$ & $4.31 \times 10^{18}$ \\
\hline $\begin{array}{c}\text { Intermediate to Lower Shell } \\
\text { Circumferential Weld Seam }\end{array}$ & $1.98 \times 10^{19}$ & $1.19 \times 10^{19}$ & $4.31 \times 10^{18}$ \\
\hline
\end{tabular}

Notes:

(a) These fluence values were obtained from the calculated fluence values given in Table 6-13 of WCAP-15117 and Table 4-1 in WCAP-15118.

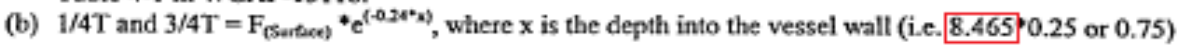

Figure A-3. Excerpt from [A60]

The neutron fluence is calculated for "vessel 1T thickness" using Equation A1 as shown below:

$$
f_{1 T}=1.98 \cdot 10^{19}\left(e^{-0.24 \cdot(8.465)}\right)=0.26 \cdot 10^{19} \frac{\mathrm{n}}{\mathrm{cm}^{2}}
$$

The vessel outside surface (1T) neutron fluence for 80 years with $92 \%$ CF is calculated using Equation A2 as shown below:

$$
f_{1 T @ 80 y r}=\left(\frac{73.6}{34}\right) \times 0.26 \cdot 10^{19}=5.62 \cdot 10^{18} \frac{\mathrm{n}}{\mathrm{cm}^{2}}
$$



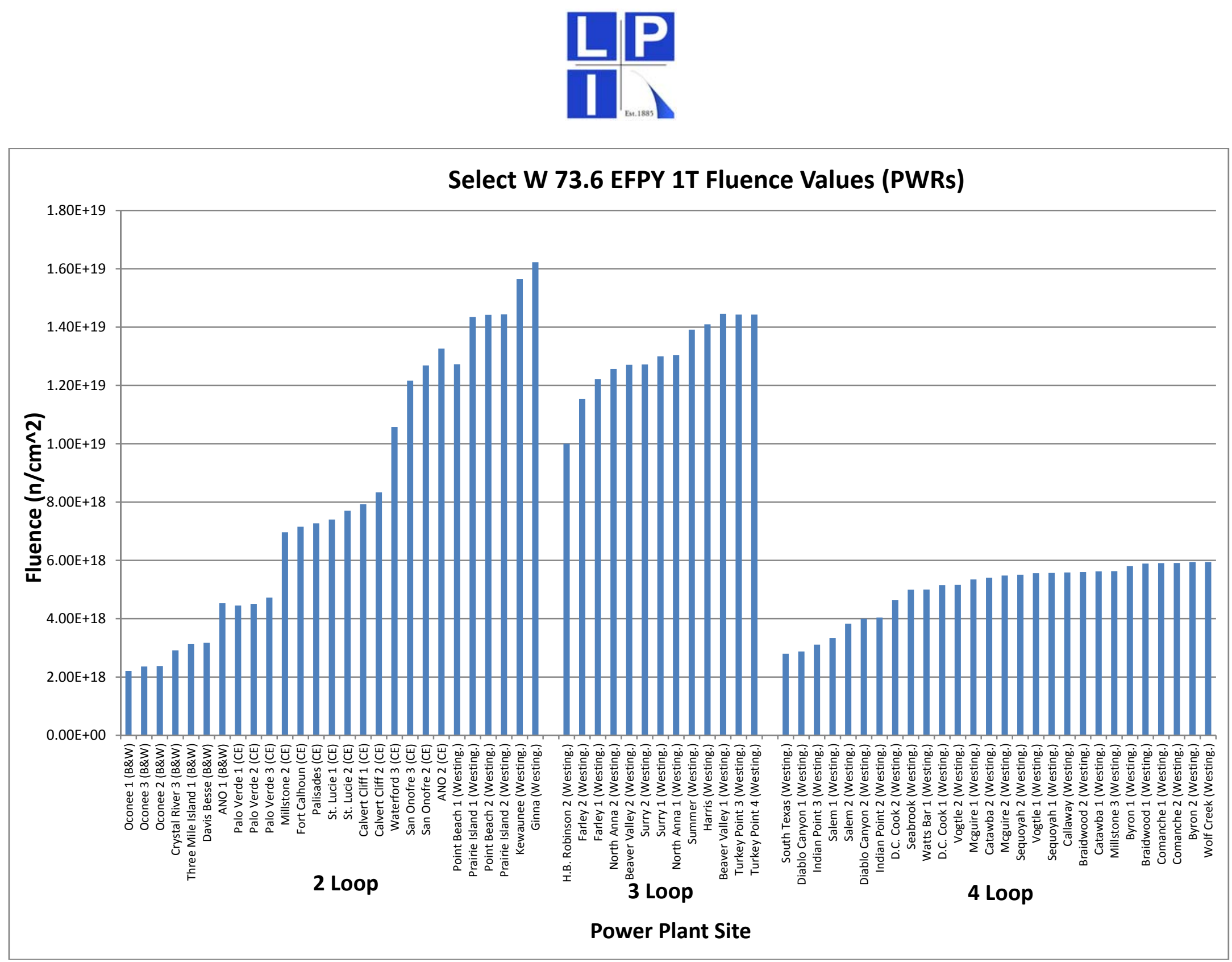

Figure A-4. PWR Neutron Fluence Values at 1T Location for 80 Years with 92\%CF

Report No. A13276-R-001

Revision 0
Attachment A

Page $A 6$ of 20 

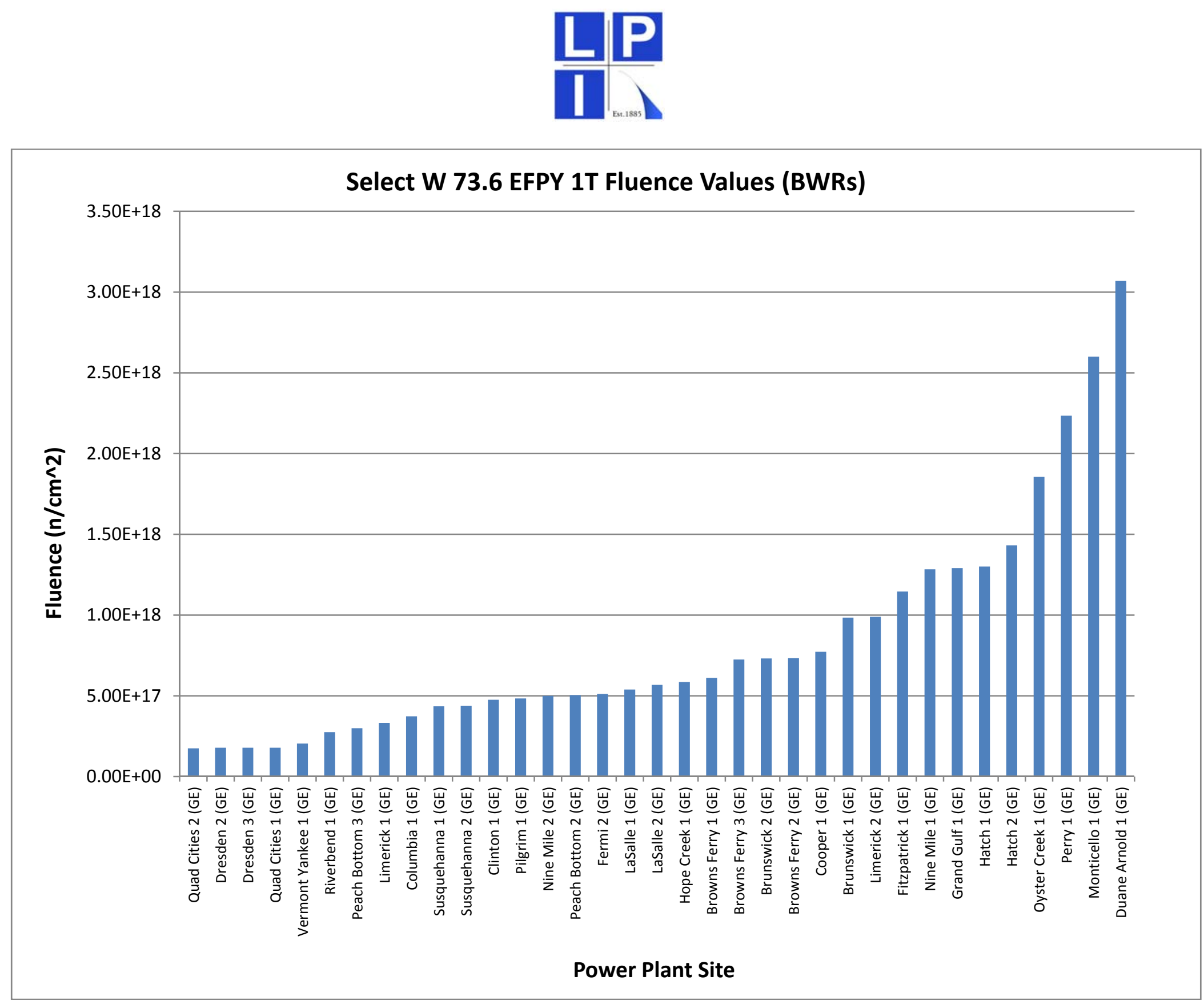

Figure A-5. BWR Neutron Fluence Values at 1T Location for 80 Years with 92\%CF

Report No. A13276-R-001

Revision 0
Attachment A

Page $A 7$ of 20 


\section{LP}

Table A-1. Power Plant Information for Neutron Vessel Wall Fluence Calculation

\begin{tabular}{|c|c|c|c|c|c|c|c|c|c|c|c|}
\hline $\begin{array}{l}\text { Plant } \\
\text { Type }\end{array}$ & Loops & $\begin{array}{l}\text { Plant (NSSS } \\
\text { Supplier) }\end{array}$ & EFPY & $\begin{array}{c}\text { 0т } \\
\left(\times 10^{\wedge} 19 \mathrm{n} / \mathrm{cm}^{\wedge} 2\right)\end{array}$ & $\begin{array}{c}1 / 4 \mathrm{~T} \\
\left(\times 10^{\wedge} 19 \mathrm{n} / \mathrm{cm}^{\wedge} 2\right)\end{array}$ & $\begin{array}{c}3 / 4 \mathrm{~T} \\
\left(\times 10^{\wedge} 19 \mathrm{n} / \mathrm{cm}^{\wedge} 2\right)\end{array}$ & $\begin{array}{c}1 \mathrm{~T} \\
\left(\times 10^{\wedge} 19 \mathrm{n} / \mathrm{cm}^{\wedge} 2\right)\end{array}$ & $\begin{array}{l}\text { RPV wall } \\
\text { (in) }\end{array}$ & Reference & CF yrs & $1 \mathrm{~T}\left(\mathrm{n} / \mathrm{cm}^{\wedge} 2\right)$ \\
\hline PWR & 2 & Oconee 1 (B\&W) & 48.00 & 1.18 & 0.62 & 0.24 & 0.14 & 8.764 & [A1] & 73.6 & $2.21 E+18$ \\
\hline PWR & 2 & Oconee 3 (B\&W) & 48.00 & 1.26 & 0.73 & 0.26 & 0.15 & 8.764 & [A1] & 73.6 & $2.36 \mathrm{E}+18$ \\
\hline PWR & 2 & Oconee 2 (B\&W) & 48.00 & 1.27 & 0.75 & 0.26 & 0.15 & 8.764 & [A1] & 73.6 & $2.38 \mathrm{E}+18$ \\
\hline PWR & 2 & 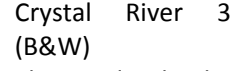 & 54.00 & 1.62 & 0.95 & 0.34 & 0.21 & 8.440 & [A2] & 73.6 & $2.91 \mathrm{E}+18$ \\
\hline PWR & 2 & $\begin{array}{l}\text { Three Mile Island } 1 \\
\text { (B\&W) }\end{array}$ & 29.00 & 1.04 & 0.61 & 0.22 & 0.12 & 8.878 & {$[\mathrm{~A} 3]$} & 73.6 & $3.13 E+18$ \\
\hline PWR & 2 & Davis Besse (B\&W) & 52.00 & 1.70 & 0.99 & 0.37 & 0.22 & 8.440 & [A4] & 73.6 & $3.17 E+18$ \\
\hline PWR & 2 & ANO 1 (B\&W) & 48.00 & 1.44 & 0.97 & 0.44 & 0.30 & 6.600 & {$[\mathrm{~A} 5][\mathrm{A} 6]$} & 73.6 & $4.53 \mathrm{E}+18$ \\
\hline PWR & 2 & Palo Verde 1 (CE) & 32.00 & 1.64 & 0.95 & 0.32 & 0.19 & 8.903 & [A7] & 73.6 & $4.45 \mathrm{E}+18$ \\
\hline PWR & 2 & Palo Verde 2 (CE) & 32.00 & 1.66 & 0.96 & 0.33 & 0.20 & 8.902 & [A8] & 73.6 & $4.51 \mathrm{E}+18$ \\
\hline PWR & 2 & Palo Verde 3 (CE) & 32.00 & 1.74 & 1.01 & 0.34 & 0.21 & 8.902 & [A9] & 73.6 & $4.73 E+18$ \\
\hline PWR & 2 & Millstone 2 (CE) & 32.00 & 2.40 & 1.43 & 0.51 & 0.30 & 8.626 & [A10] & 73.6 & $6.96 \mathrm{E}+18$ \\
\hline PWR & 2 & Fort Calhoun (CE) & 40.00 & 2.15 & 1.40 & 0.60 & 0.39 & 7.125 & [A11] & 73.6 & $7.16 \mathrm{E}+18$ \\
\hline PWR & 2 & Palisades (CE) & 42.10 & 3.43 & 2.02 & 0.71 & 0.42 & 8.790 & [A12] & 73.6 & $7.27 \mathrm{E}+18$ \\
\hline PWR & 2 & St. Lucie 1 (CE) & 32.00 & 2.55 & 1.52 & 0.54 & 0.32 & 8.625 & [A13] [A14] & 73.6 & $7.40 \mathrm{E}+18$ \\
\hline PWR & 2 & St. Lucie 2 (CE) & 55.00 & 4.56 & 2.72 & 0.97 & 0.58 & 8.625 & [A15] & 73.6 & $7.70 \mathrm{E}+18$ \\
\hline PWR & 2 & Calvert Cliff 1 (CE) & 32.00 & 2.73 & 1.63 & 0.58 & 0.34 & 8.625 & [A16] & 73.6 & $7.92 \mathrm{E}+18$ \\
\hline PWR & 2 & Calvert Cliff 2 (CE) & 32.00 & 2.87 & 1.71 & 0.61 & 0.36 & 8.625 & [A17] & 73.6 & $8.33 E+18$ \\
\hline PWR & 2 & Waterford 3 (CE) & 32.00 & 3.64 & 1.95 & 0.77 & 0.46 & 8.622 & [A18] [A19] & 73.6 & $1.06 \mathrm{E}+19$ \\
\hline PWR & 2 & San Onofre 3 (CE) & 32.00 & 4.19 & 2.37 & 0.84 & 0.53 & 8.625 & [A20] & 73.6 & $1.22 \mathrm{E}+19$ \\
\hline PWR & 2 & San Onofre 2 (CE) & 32.00 & 4.37 & 2.47 & 0.88 & 0.55 & 8.625 & [A21] & 73.6 & $1.27 \mathrm{E}+19$ \\
\hline PWR & 2 & ANO 2 (CE) & 32.00 & 3.63 & 2.29 & 0.89 & 0.58 & 7.666 & [A22] & 73.6 & $1.33 \mathrm{E}+19$ \\
\hline PWR & 2 & $\begin{array}{l}\text { Point Beach } 1 \\
\text { (Westing.) }\end{array}$ & 32.20 & 2.65 & 1.79 & 0.82 & 0.56 & 6.500 & [A23] & 73.6 & 1.27E+19 \\
\hline PWR & 2 & (Westing.) & 54.00 & 5.16 & 3.47 & 1.57 & 1.05 & 6.626 & {$[\mathrm{~A} 24][\mathrm{A} 25]$} & 73.6 & $1.43 E+19$ \\
\hline PWR & 2 & $\begin{array}{l}\text { Point Beach } 2 \\
\text { (Westing.) }\end{array}$ & 34.00 & 3.17 & 2.15 & 0.99 & 0.67 & 6.500 & [A23] & 73.6 & $1.44 \mathrm{E}+19$ \\
\hline
\end{tabular}




\title{
LP \\ I.
}

\begin{tabular}{|c|c|c|c|c|c|c|c|c|c|c|c|}
\hline $\begin{array}{l}\text { Plant } \\
\text { Type }\end{array}$ & Loops & $\begin{array}{l}\text { Plant (NSSS } \\
\text { Supplier) }\end{array}$ & EFPY & $\begin{array}{c}\text { от } \\
\left(\times 10^{\wedge} 19 \mathrm{n} / \mathrm{cm}^{\wedge} 2\right)\end{array}$ & $\begin{array}{c}1 / 4 \mathrm{~T} \\
\left(\times 10^{\wedge} 19 \mathrm{n} / \mathrm{cm}^{\wedge} 2\right)\end{array}$ & $\begin{array}{c}3 / 4 \mathrm{~T} \\
\left(\times 10^{\wedge} 19 \mathrm{n} / \mathrm{cm}^{\wedge} 2\right)\end{array}$ & $\begin{array}{c}1 \mathbf{T} \\
\left(\times 10^{\wedge} 19 \mathrm{n} / \mathrm{cm}^{\wedge} 2\right)\end{array}$ & $\begin{array}{l}\text { RPV wall } \\
\text { (in) }\end{array}$ & Reference & CF yrs & $1 T\left(\mathrm{n} / \mathrm{cm}^{\wedge} 2\right)$ \\
\hline PWR & 2 & $\begin{array}{ll}\text { Prairie Island } 2 \\
\text { (Westing.) } \\
\text { Kewaunee } \\
\text { (Westing.) }\end{array}$ & $\begin{array}{l}54.00 \\
33.00\end{array}$ & 3.44 & 3.33 & 1.07 & 0.70 & 6.626 & {$[\mathrm{~A} 26]$} & 73.6 & $1.56 \mathrm{E}+19$ \\
\hline PWR & 2 & Ginna (Westing.) & 53.00 & 5.56 & 3.76 & 1.73 & 1.17 & 6.500 & [A27] & 73.6 & $1.62 \mathrm{E}+19$ \\
\hline PWR & 3 & (Westing.) & 29.00 & 3.67 & 2.10 & 0.69 & 0.39 & 9.297 & [A28] & 73.6 & $1.00 \mathrm{E}+19$ \\
\hline PWR & 3 & Farley 2 (Westing.) & 36.00 & 3.73 & 2.33 & 0.90 & 0.56 & 7.875 & [A29] & 73.6 & $1.15 \mathrm{E}+19$ \\
\hline PWR & 3 & Farley 1 (Westing.) & 54.00 & 5.93 & 3.70 & 1.44 & 0.90 & 7.875 & [A30] [A31] & 73.6 & $1.22 \mathrm{E}+19$ \\
\hline PWR & 3 & $\begin{array}{l}\text { North Anna } 2 \\
\text { (Westing.) }\end{array}$ & 52.30 & 5.91 & 3.69 & 1.44 & 0.89 & 7.875 & {$[\mathrm{~A} 32]$} & 73.6 & $1.26 \mathrm{E}+19$ \\
\hline PWR & 3 & $\begin{array}{l}\text { Beaver Valley } 2 \\
\text { (Westing.) }\end{array}$ & 36.00 & 4.11 & 2.56 & 1.00 & 0.62 & 7.874 & [A33] & 73.6 & $1.27 \mathrm{E}+19$ \\
\hline PWR & 3 & Surry 2 (Westing.) & 48.10 & 5.34 & 3.26 & 1.21 & 0.83 & 7.750 & [A32] & 73.6 & $1.27 \mathrm{E}+19$ \\
\hline PWR & 3 & Surry 1 (Westing.) & 47.60 & 5.40 & 3.29 & 1.23 & 0.84 & 7.750 & [A32] & 73.6 & $1.30 \mathrm{E}+19$ \\
\hline PWR & 3 & $\begin{array}{l}\text { North Anna } 1 \\
\text { (Westing.) }\end{array}$ & 50.30 & 5.90 & 3.68 & 1.43 & 0.89 & 7.875 & {$[\mathrm{~A} 32]$} & 73.6 & $1.30 \mathrm{E}+19$ \\
\hline PWR & 3 & $\begin{array}{l}\text { Summer } \\
\text { (Westing.) }\end{array}$ & 56.00 & 6.80 & 4.27 & 1.69 & 1.06 & 7.750 & [A34] & 73.6 & $1.39 \mathrm{E}+19$ \\
\hline PWR & 3 & Harris (Westing.) & 36.00 & 4.61 & 2.81 & 1.11 & 0.69 & 7.917 & [A35] & 73.6 & $1.41 \mathrm{E}+19$ \\
\hline PWR & 3 & (Westing.) & 45.00 & 5.85 & 3.65 & 1.42 & 0.88 & 7.874 & [A36] & 73.6 & $1.45 \mathrm{E}+19$ \\
\hline PWR & 3 & $\begin{array}{l}\text { Turkey Point } 3 \\
\text { (Westing.) }\end{array}$ & 32.00 & 4.03 & 2.53 & 1.00 & 0.63 & 7.750 & [A37] & 73.6 & $1.44 \mathrm{E}+19$ \\
\hline PWR & 3 & $\begin{array}{l}\text { Turkey Point } 4 \\
\text { (Westing.) }\end{array}$ & 32.00 & 4.03 & 2.53 & 1.00 & 0.63 & 7.750 & [A38] & 73.6 & $1.44 \mathrm{E}+19$ \\
\hline PWR & 4 & $\begin{array}{l}\text { South } \\
\text { (Westing.) }\end{array}$ & 34.00 & 2.51 & 1.50 & 0.53 & 0.32 & 8.630 & [A39] & 73.6 & $2.80 \mathrm{E}+18$ \\
\hline PWR & 4 & $\begin{array}{l}\text { Diablo Canyon } 1 \\
\text { (Westing.) }\end{array}$ & 32.00 & 1.26 & 0.75 & 0.27 & 0.13 & 9.625 & [A40] & 73.6 & $2.88 \mathrm{E}+18$ \\
\hline PWR & 4 & $\begin{array}{l}\text { Indian Point } 3 \\
\text { (Westing.) }\end{array}$ & 27.10 & 0.92 & 0.55 & 0.20 & 0.11 & 8.689 & {$[\mathrm{~A} 41]$} & 73.6 & $3.11 \mathrm{E}+18$ \\
\hline PWR & 4 & Salem 1 (Westing.) & 42.00 & 1.59 & 0.94 & 0.32 & 0.19 & 8.840 & {$[\mathrm{~A} 42]$} & 73.6 & $3.34 \mathrm{E}+18$ \\
\hline PWR & 4 & Salem 2 (Westing.) & 32.00 & 1.34 & 0.80 & 0.28 & 0.17 & 8.689 & [A43] & 73.6 & $3.83 \mathrm{E}+18$ \\
\hline PWR & 4 & $\begin{array}{l}\text { Diablo Canyon } 2 \\
\text { (Westing.) }\end{array}$ & 32.00 & 1.40 & 0.83 & 0.30 & 0.17 & 8.689 & [A44] & 73.6 & $4.00 \mathrm{E}+18$ \\
\hline PWR & 4 & $\begin{array}{l}\text { Indian Point } \\
\text { (Westing.) }\end{array}$ & 32.00 & 1.39 & 0.90 & 0.35 & 0.18 & 8.622 & [A45] & 73.6 & $4.04 \mathrm{E}+18$ \\
\hline
\end{tabular}

\author{
Report No. A13276-R-001 \\ Revision 0
}

Attachment A

Page A9 of 20 


\section{LPP \\ I.}

\begin{tabular}{|c|c|c|c|c|c|c|c|c|c|c|c|}
\hline $\begin{array}{l}\text { Plant } \\
\text { Type }\end{array}$ & Loops & $\begin{array}{l}\text { Plant (NSSS } \\
\text { Supplier) }\end{array}$ & EFPY & $\begin{array}{c}\text { OT } \\
\left(\times 10^{\wedge} 19 \mathrm{n} / \mathrm{cm}^{\wedge} 2\right)\end{array}$ & $\begin{array}{c}1 / 4 \mathbf{T} \\
\left(\times 10^{\wedge} 19 \mathrm{n} / \mathrm{cm}^{\wedge} 2\right)\end{array}$ & $\begin{array}{c}3 / 4 \mathbf{T} \\
\left(\times 10^{\wedge} 19 \mathrm{n} / \mathrm{cm}^{\wedge} 2\right)\end{array}$ & $\begin{array}{c}1 \mathbf{T} \\
\left(\times 10^{\wedge} 19 \mathrm{n} / \mathrm{cm}^{\wedge} 2\right)\end{array}$ & $\begin{array}{l}\text { RPV wall } \\
\text { (in) }\end{array}$ & Reference & CF yrs & $1 \mathbf{T}\left(\mathrm{n} / \mathrm{cm}^{\wedge} 2\right)$ \\
\hline PWR & 4 & $\begin{array}{l}\text { D.C. Cook } 2 \\
\text { (Westing.) }\end{array}$ & 32.00 & 1.63 & 0.98 & 0.35 & 0.20 & 8.689 & [A46] & 73.6 & $4.64 \mathrm{E}+18$ \\
\hline PWR & 4 & $\begin{array}{l}\text { Seabrook } \\
\text { (Westing.) }\end{array}$ & 32.00 & 1.72 & 1.02 & 0.36 & 0.22 & 8.622 & [A47] & 73.6 & $5.00 E+18$ \\
\hline PWR & 4 & $\begin{array}{l}\text { Watts Bar } \quad 1 \\
\text { (Westing.) }\end{array}$ & 32.00 & 1.75 & 1.05 & 0.38 & 0.22 & 8.689 & [A48] & 73.6 & $5.00 \mathrm{E}+18$ \\
\hline PWR & 4 & $\begin{array}{l}\text { D.C. Cook } 1 \\
\text { (Westing.) }\end{array}$ & 32.00 & 1.80 & 1.08 & 0.39 & 0.22 & 8.689 & [A49] & 73.6 & $5.15 \mathrm{E}+18$ \\
\hline PWR & 4 & Vogtle 2 (Westing.) & 36.00 & 2.00 & 1.19 & 0.42 & 0.25 & 8.625 & [A50] & 73.6 & $5.16 \mathrm{E}+18$ \\
\hline PWR & 4 & $\begin{array}{ll}\text { McGuire } & 1 \\
\text { (Westing.) } & \end{array}$ & 34.00 & 1.96 & 1.17 & 0.42 & 0.25 & 8.630 & [A51] & 73.6 & $5.35 E+18$ \\
\hline PWR & 4 & $\begin{array}{l}\text { Catawba } \\
\text { (Westing.) }\end{array}$ & 34.00 & 2.01 & 1.20 & 0.43 & 0.25 & 8.689 & [A52] & 73.6 & $5.41 \mathrm{E}+18$ \\
\hline PWR & 4 & $\begin{array}{l}\text { McGuire } \\
\text { (Westing.) }\end{array}$ & 34.00 & 1.93 & 1.16 & 0.42 & 0.25 & 8.465 & [A53] & 73.6 & $5.48 \mathrm{E}+18$ \\
\hline PWR & 4 & $\begin{array}{l}\text { Sequoyah } \\
\text { (Westing.) }\end{array}$ & 32.00 & 1.82 & 1.10 & 0.40 & 0.24 & 8.450 & [A54] [A55] & 73.6 & $5.51 \mathrm{E}+18$ \\
\hline PWR & 4 & Vogtle 1 (Westing.) & 36.00 & 2.16 & 1.28 & 0.46 & 0.27 & 8.625 & [A56] & 73.6 & $5.56 \mathrm{E}+18$ \\
\hline PWR & 4 & $\begin{array}{ll}\text { Sequoyah } & 1 \\
\text { (Westing.) } & \\
\text { Callaway } & \end{array}$ & 32.00 & 1.84 & 1.11 & 0.40 & 0.24 & 8.450 & [A57] & 73.6 & $5.57 E+18$ \\
\hline PWR & 4 & $\begin{array}{l}\text { (Westing.) } \\
\text { Braidwood }\end{array}$ & 20.00 & 1.20 & 0.72 & 0.25 & 0.15 & 8.630 & [A58] & 73.6 & $5.58 \mathrm{E}+18$ \\
\hline PWR & 4 & $\begin{array}{l}\text { (Westing.) } \\
\text { Catawba }\end{array}$ & 32.00 & 1.96 & 1.18 & 0.42 & 0.24 & 8.689 & [A59] & 73.6 & $5.60 \mathrm{E}+18$ \\
\hline PWR & 4 & $\begin{array}{l}\text { (Westing.) } \\
\text { Millstone }\end{array}$ & 34.00 & 1.98 & 1.19 & 0.43 & 0.26 & 8.465 & [A60] & 73.6 & $5.62 E+18$ \\
\hline PWR & 4 & (Westing.) & 32.00 & 1.97 & 1.17 & 0.42 & 0.24 & 8.689 & [A61] & 73.6 & $5.63 \mathrm{E}+18$ \\
\hline PWR & 4 & Byron 1 (Westing.) & 48.00 & 2.91 & 1.75 & 0.63 & 0.38 & 8.500 & [A62] & 73.6 & $5.80 \mathrm{E}+18$ \\
\hline PWR & 4 & $\begin{array}{ll}\text { Braidwood } & 1 \\
\text { (Westing.) } & \end{array}$ & 32.00 & 1.97 & 1.18 & 0.43 & 0.26 & 8.500 & [A63] [A64] & 73.6 & $5.89 \mathrm{E}+18$ \\
\hline PWR & 4 & $\begin{array}{l}\text { Comanche } \\
\text { (Westing.) }\end{array}$ & 34.00 & 2.16 & 1.29 & 0.46 & 0.27 & 8.622 & [A65] & 73.6 & $5.90 \mathrm{E}+18$ \\
\hline PWR & 4 & $\begin{array}{l}\text { Comanche } \\
\text { (Westing.) }\end{array}$ & 36.00 & 2.29 & 1.36 & 0.48 & 0.29 & 8.622 & [A66] & 73.6 & $5.91 \mathrm{E}+18$ \\
\hline PWR & 4 & Byron 2 (Westing.) & 48.00 & 2.98 & 1.79 & 0.65 & 0.39 & 8.500 & [A62] & 73.6 & $5.94 \mathrm{E}+18$ \\
\hline PWR & 4 & $\begin{array}{ll}\text { Wolf } & \text { Creek } \\
\text { (Westing.) }\end{array}$ & 54.00 & 3.51 & 2.09 & 0.74 & 0.44 & 8.689 & [A67] & 73.6 & $5.94 \mathrm{E}+18$ \\
\hline
\end{tabular}




\section{LP \\ I.}

\begin{tabular}{|c|c|c|c|c|c|c|c|c|c|c|c|}
\hline $\begin{array}{l}\text { Plant } \\
\text { Type }\end{array}$ & Loops & $\begin{array}{l}\text { Plant (NSSS } \\
\text { Supplier) }\end{array}$ & EFPY & $\begin{array}{c}\text { OT } \\
\left(\times 10^{\wedge} 19 \mathrm{n} / \mathrm{cm}^{\wedge} 2\right)\end{array}$ & $\begin{array}{c}1 / 4 \mathrm{~T} \\
\left(\times 10^{\wedge} 19 \mathrm{n} / \mathrm{cm}^{\wedge} 2\right)\end{array}$ & $\begin{array}{c}3 / 4 \mathrm{~T} \\
\left(\times 10^{\wedge} 19 \mathrm{n} / \mathrm{cm}^{\wedge} 2\right)\end{array}$ & $\begin{array}{c}1 \mathrm{~T} \\
\left(\times 10^{\wedge} 19 \mathrm{n} / \mathrm{cm}^{\wedge} 2\right)\end{array}$ & $\begin{array}{l}\text { RPV wall } \\
\text { (in) }\end{array}$ & Reference & CF yrs & $1 \mathrm{~T}\left(\mathrm{n} / \mathrm{cm}^{\wedge} 2\right)$ \\
\hline BWR & & Quad Cities 2 (GE) & 32.00 & 0.033 & 0.023 & 0.011 & 0.008 & 6.125 & [A68] & 73.6 & $1.75 \mathrm{E}+17$ \\
\hline BWR & & Dresden 2 (GE) & 54.00 & 0.057 & 0.039 & 0.019 & 0.013 & 6.130 & [A69] & 73.6 & $1.78 \mathrm{E}+17$ \\
\hline BWR & & Dresden 3 (GE) & 54.00 & 0.057 & 0.039 & 0.019 & 0.013 & 6.130 & [A70] & 73.6 & $1.78 \mathrm{E}+17$ \\
\hline BWR & & Quad Cities 1 (GE) & 54.00 & 0.057 & 0.039 & 0.019 & 0.013 & 6.130 & [A71] & 73.6 & $1.78 \mathrm{E}+17$ \\
\hline BWR & & $\begin{array}{l}\text { Vermont Yankee I } \\
\text { (GE) }\end{array}$ & 32.00 & 0.030 & 0.021 & 0.009 & 0.009 & 5.060 & [A72] & 73.6 & $2.04 \mathrm{E}+17$ \\
\hline BWR & & River Bend 1 (GE) & 32.00 & 0.044 & 0.032 & 0.013 & 0.012 & 5.406 & [A73] & 73.6 & $2.75 E+17$ \\
\hline BWR & & $\begin{array}{l}\text { Peach Bottom } 3 \\
\text { (GE) }\end{array}$ & 54.00 & 0.095 & 0.066 & 0.032 & 0.022 & 6.125 & [A74] & 73.6 & $2.99 \mathrm{E}+17$ \\
\hline BWR & & Limerick 1 (GE) & 37.00 & 0.078 & 0.053 & 0.025 & 0.017 & 6.430 & [A75] & 73.6 & $3.33 E+17$ \\
\hline BWR & & Columbia 1 (GE) & 33.10 & 0.074 & 0.051 & 0.024 & 0.017 & 6.188 & [A76] & 73.6 & $3.73 E+17$ \\
\hline BWR & & $\begin{array}{ll}\text { Susquehanna } & 1 \\
\text { (GE) } & \end{array}$ & 54.00 & 0.141 & 0.095 & 0.034 & 0.032 & 6.188 & [A77] [A78] & 73.6 & $4.35 E+17$ \\
\hline BWR & & $\begin{array}{l}\text { Susquehanna } \\
\text { (GE) }\end{array}$ & 54.00 & 0.142 & 0.095 & 0.034 & 0.032 & 6.188 & [A77] [A78] & 73.6 & $4.38 \mathrm{E}+17$ \\
\hline BWR & & Clinton 1 (GE) & 32.00 & 0.081 & 0.058 & 0.029 & 0.021 & 5.690 & [A79] & 73.6 & $4.75 \mathrm{E}+17$ \\
\hline BWR & & Pilgrim 1 (GE) & 34.00 & 0.084 & 0.060 & 0.031 & 0.022 & 5.531 & [A80] & 73.6 & $4.83 E+17$ \\
\hline BWR & & Nine Mile 2 (GE) & 32.00 & 0.096 & 0.066 & 0.032 & 0.022 & 6.188 & [A81] & 73.6 & $5.00 \mathrm{E}+17$ \\
\hline BWR & & $\begin{array}{l}\text { Peach Bottom } 2 \\
\text { (GE) }\end{array}$ & 54.00 & 0.161 & 0.111 & 0.053 & 0.037 & 6.125 & [A74] & 73.6 & $5.05 E+17$ \\
\hline BWR & & Fermi 2 (GE) & 32.00 & 0.097 & 0.067 & 0.032 & 0.022 & 6.125 & [A82] & 73.6 & $5.12 \mathrm{E}+17$ \\
\hline BWR & & LaSalle 1 (GE) & 32.00 & 0.102 & 0.071 & 0.034 & 0.023 & 6.130 & [A83] & 73.6 & $5.39 E+17$ \\
\hline BWR & & LaSalle 2 (GE) & 32.00 & 0.109 & 0.075 & 0.036 & 0.025 & 6.190 & [A83] & 73.6 & $5.68 \mathrm{E}+17$ \\
\hline BWR & & Hope Creek 1 (GE) & 32.00 & 0.110 & 0.076 & 0.037 & 0.025 & 6.100 & [A84] & 73.6 & $5.85 \mathrm{E}+17$ \\
\hline BWR & & $\begin{array}{lll}\text { Browns } & \text { Ferry } & 1 \\
\text { (GE) } & & \\
\text { Browns } & \text { Ferry } & 3\end{array}$ & 54.00 & 0.195 & 0.135 & 0.065 & 0.045 & 6.125 & [A85] [A86] & 73.6 & $6.11 \mathrm{E}+17$ \\
\hline BWR & & (GE) & 28.00 & 0.120 & 0.086 & 0.040 & 0.028 & 6.130 & [A87] & 73.6 & $7.24 E+17$ \\
\hline BWR & & Brunswick 2 (GE) & 32.00 & 0.118 & 0.085 & 0.044 & 0.032 & 5.466 & [A88] & 73.6 & $7.31 E+17$ \\
\hline BWR & & $\begin{array}{l}\text { Browns Ferry } 2 \\
\text { (GE) }\end{array}$ & 30.00 & 0.130 & 0.092 & 0.043 & 0.030 & 6.130 & [A87] & 73.6 & $7.32 \mathrm{E}+17$ \\
\hline BWR & & Cooper 1 (GE) & 32.00 & 0.122 & 0.083 & 0.032 & 0.034 & 5.375 & [A89] & 73.6 & $7.72 \mathrm{E}+17$ \\
\hline BWR & & Brunswick 1 (GE) & 32.00 & 0.160 & 0.115 & 0.059 & 0.043 & 5.496 & [A88] & 73.6 & $9.84 \mathrm{E}+17$ \\
\hline
\end{tabular}

\footnotetext{
Report No. A13276-R-001
}

Revision 0

Attachment A

Page A11 of 20 


\section{LP I.}

\begin{tabular}{|c|c|c|c|c|c|c|c|c|c|c|c|}
\hline $\begin{array}{l}\text { Plant } \\
\text { Type }\end{array}$ & Loops & $\begin{array}{l}\text { Plant (NSSS } \\
\text { Supplier) }\end{array}$ & EFPY & $\begin{array}{c}\text { от } \\
\left(\times 10^{\wedge} 19 \mathrm{n} / \mathrm{cm}^{\wedge} 2\right)\end{array}$ & $\begin{array}{c}1 / 4 \mathrm{~T} \\
\left(\times 10^{\wedge} 19 \mathrm{n} / \mathrm{cm}^{\wedge} 2\right)\end{array}$ & $\begin{array}{c}3 / 4 \mathbf{T} \\
\left(\times 10^{\wedge} 19 \mathrm{n} / \mathrm{cm}^{\wedge} 2\right)\end{array}$ & $\begin{array}{c}1 T \\
\left(\times 10^{\wedge} 19 \mathrm{n} / \mathrm{cm}^{\wedge} 2\right)\end{array}$ & $\begin{array}{l}\text { RPV wall } \\
\text { (in) }\end{array}$ & Reference & CF yrs & $1 T\left(\mathrm{n} / \mathrm{cm}^{\wedge} 2\right)$ \\
\hline BWR & & Limerick 2 (GE) & 32.00 & 0.190 & 0.130 & 0.062 & 0.043 & 6.190 & [A90] & 73.6 & $9.89 \mathrm{E}+17$ \\
\hline BWR & & Fitzpatrick 1 (GE) & 32.00 & 0.181 & 0.131 & 0.069 & 0.050 & 5.375 & [A91] & 73.6 & $1.15 \mathrm{E}+18$ \\
\hline BWR & & Nine Mile 1 (GE) & 28.00 & 0.270 & 0.176 & 0.075 & 0.049 & 7.125 & [A92] & 73.6 & $1.28 \mathrm{E}+18$ \\
\hline BWR & & Grand Gulf 1 (GE) & 54.00 & 0.444 & 0.302 & 0.139 & 0.095 & 6.438 & [A93] & 73.6 & $1.29 \mathrm{E}+18$ \\
\hline BWR & & Hatch 1 (GE) & 54.00 & 0.347 & 0.251 & 0.132 & 0.095 & 5.380 & [A94] & 73.6 & $1.30 \mathrm{E}+18$ \\
\hline BWR & & Hatch 2 (GE) & 54.00 & 0.382 & 0.277 & 0.145 & 0.105 & 5.380 & [A94] & 73.6 & $1.43 \mathrm{E}+18$ \\
\hline BWR & & Oyster Creek 1 (GE) & 50.00 & 0.697 & 0.439 & 0.193 & 0.126 & 7.125 & [A95] & 73.6 & $1.86 \mathrm{E}+18$ \\
\hline BWR & & Perry 1 (GE) & 32.00 & 0.410 & 0.290 & 0.139 & 0.097 & 6.000 & [A96] & 73.6 & $2.23 E+18$ \\
\hline BWR & & Monticello 1 (GE) & 54.00 & 0.643 & 0.475 & 0.258 & 0.191 & 5.063 & [A97] & 73.6 & $2.60 E+18$ \\
\hline BWR & & $\begin{array}{l}\text { Duane Arnold } 1 \\
\text { (GE) }\end{array}$ & 32.00 & 0.390 & 0.298 & 0.174 & 0.133 & 4.469 & [A98] & 73.6 & $3.07 \mathrm{E}+18$ \\
\hline
\end{tabular}




\section{LPP \\ I.}

\section{A3.0 REFERENCES}

A1. "Oconee Nuclear Station UFSAR Supplement," Docket Nos.50-269, -270, 287, March 27, 2000.

A2. "License Renewal Application," Crystal River Unit 3, Aging Management Programs.

A3. "License Amendment Request No.308 - Pressure Temperature Operating Curves," Three Mile Island Unit 1, Docket No.50-289, March 29, 2001.

A4. "Davis-Besse Nuclear Power Station License Renewal Application," Aging Management Review Results, August 2010.

A5. "License Renewal Application," Arkansas Nuclear One - Unit 1, Docket No.50313, January 31, 2000.

A6. "Proposed Alternative to ASME Weld Examination Requirements for Repairs Performed on Reactor Vessel Head Penetration Nozzles," CNRO-200400026, Arkansas Nuclear One, Docket No.50-313, May 4, 2004.

A7. "Analysis of Capsule $38^{\circ}$ from the Arizona Public Service Company Palo Verde Unit 1 Reactor Vessel Radiation Surveillance Program," WCAP-15589 Rev.1, March 2003.

A8. "Analysis of Capsule $230^{\circ}$ from Arizona Public Service Company Palo Verde Unit 2 Reactor Vessel Radiation Surveillance Program," WCAP-16524-NP Rev.0, February 2006.

A9. "Palo Verde Nuclear Generating Station Units 1, 2, and 3; Basis for RCS Pressure and Temperature Limits Report," WCAP-16835-NP Rev.0, June 2008.

A10. "Analysis of Capsule W-83 from the Dominion Nuclear Connecticut Millstone Unit 2 Reactor Vessel Radiation Surveillance Program," WCAP-16012 Rev.0, February 2003.

A11. "Pressure and Temperature (P-T) Limit Curve for 40 Effective Full Power Years (EFPY)," Fort Calhoun Station Unit No. 1 License Amendment Request, LIC-01-0114, December 14, 2001.

A12. "Palisades Nuclear Power Plant Heatup and Cooldown Limit Curves for Normal Operation and Upper-Shelf Energy Evaluation," WCAP-17341-NP Rev.0, February 2011. 


\section{LP}

A13. "Analysis of Capsule $284^{\circ}$ from the Florida Power and Light Company St. Lucie Unit 1 Reactor Vessel Radiation Surveillance Program," WCAP-15446 Rev.1, May 2, 2002.

A14. "Pressure/Temperature Curve Limits and LTOP to 35 EFPY," St. Lucie Unit 1, Docket No.50-335, December 20, 2004.

A15. "Update PT Curve and LTOP for 55 EFPY," St. Lucie Unit 2, Docket No.50389, January 23, 2008.

A16. "Analysis of Capsule $284^{\circ}$ from the Calvert Cliffs Unit No. 1 Reactor Vessel Radiation Surveillance Program," WCAP-17365-NP Rev.0, March 2011.

A17. "Analysis of Capsule $104^{\circ}$ from the Calvert Cliffs Unit No.2 Reactor Vessel Radiation Surveillance Program," WCAP-17501-NP Rev.0, February 2012.

A18. "Analysis of Capsule $263^{\circ}$ from the Entergy Operations Waterford Unit 3 Reactor Vessel Radiation Surveillance Program," WCAP-16002 Rev.0, March 2003.

A19. "Analysis of Capsule W-97," Entergy Operations, Inc., Waterford Generating Station Unit No.3, BAW-2177-01, February 2004.

A20. "Analysis of the $263^{\circ}$ Capsule Southern California Edison Company San Onofre Unit 3 Nuclear Generating Station," BAW-2454, January 2004.

A21. "Analysis of the $263^{\circ}$ Capsule Southern California Edison Company San Onofre Unit 2 Nuclear Generating Station," BAW-2408, October 2001.

A22. "Reactor Vessel Pressure-Temperature limits and Exemption from the Requirements of 10 CFR Part 50, Section 50.60(a)," Arkansas Nuclear One Unit No.2, Docket No.50-368.

A23. "Pressure and Temperature Limits Report, Rev.3" Point Beach Nuclear Plant Units 1 and 2, Docket Nos.50-266 and 50-301, February 18, 2008.

A24. "Analysis of Capsule P from the Northern States Power Company Prairie Island Unit 2 Reactor Vessel Radiation Surveillance Program," WCAP-14613 Rev.2, February 1998.

A25. "Request for Revision to Reactor Vessel Material Surveillance Capsule Withdrawal Schedule for Prairie Island Nuclear Generating Plant (PINGP)," LPI-10-029, Docket Nos.50-282 and 50-306, March 30, 2010. 


\section{LPP}

A26. "Analysis of Capsule $\mathrm{T}$ from Dominion Energy Kewaunee Power Station Reactor Vessel Radiation Surveillance Program," WCAP-16641-NP Rev.0, October 2006.

A27. "Analysis of Capsule N from the R.E. Ginna Reactor Vessel Radiation Surveillance Program," WCAP-17036-NP Rev.0, May 2009.

A28. "Analysis of Capsule $X$ from the Carolina Power and Light Company H.B. Robinson Unit 2 Reactor Vessel Radiation Surveillance Program," WCAP15805, March 2002.

A29. "Analysis of Capsule Y from the Southern Nuclear Operating Company Joseph M. Farley Unit 2 Reactor Vessel Radiation Surveillance Program," WCAP16351-NP Rev.0, February 2005.

A30. "Analysis of Capsule $Z$ from the Southern Nuclear Operating Company Joseph M. Farley Unit 1 Reactor Vessel Radiation Surveillance Program," WCAP16964-NP, October 2008.

A31. "Pressure Temperature Limits Report, Rev.1," Joseph M. Farley Nuclear Plant Unit 1, NEL-00-0062, Docket Nos.50-348 and 50-364, March 10, 2000.

A32. "Virginia Electric and Power Company (Dominion) Surry and North Anna Power Stations Units 1 and 2 Response to Request for Supplemental Information License Renewal Applications," Docket Nos.50-280, -281, -338, 339, October 15, 2002.

A33. "Analysis of Capsule $X$ from FirstEnergy Nuclear Operating Company Beaver Valley Unit 2 Reactor Vessel Radiation Surveillance Program," WCAP-16527NP Rev.0, March 2006.

A34. "Evaluation of Pressurized Thermal Shock for V.C. Summer," WCAP-16306NP Rev.0, August 2004.

A35. "Analysis of Capsule X Carolina Power \& Light Company Shearon Harris Nuclear Power Plant," BAW-2355, October 1999.

A36. "Evaluation of Pressurized Thermal Shock for Beaver Valley Unit 1," WCAP15569 Rev.0, November 2000.

A37. "Analysis of Capsule $X$ from the Florida Power and Light Company Turkey Point Unit 3 Reactor Vessel Radiation Surveillance Program," WCAP-15916 Rev.0, September 2002. 


\section{늘}

A38. "Update to NRC Reactor Vessel Integrity Database and Exemption Request for Alternate Material Properties Bases," Turkey Point Units 3 and 4, Docket Nos.50-250 and 50-251, March 18, 2009.

A39. "Analysis of Capsule W from the South Texas Unit 1 Reactor Vessel Radiation Surveillance Program," WCAP-17482-NP Rev.0, May 2012.

A40. "Analysis of Capsule V from Pacific Gas and Electric Company Diablo Canyon Unit 1 Reactor Vessel Radiation Surveillance Program," WCAP-15958 Rev.0, January 2003.

A41. "Analysis of Capsule $X$ from Entergy's Indian Point Unit 3 Reactor Vessel Radiation Surveillance Program," WCAP-16251-NP Rev.0, July 2004.

A42. "Relief Requests to Extend the Inservice Inspection Interval for Reactor Vessel Weld Examinations," LR-N09-0126, Docket Nos.50-272 and 50-311, June 11, 2009.

A43. "Analysis of Capsule $Y$ from Salem Unit 2 Reactor Vessel Radiation Surveillance Program," WCAP-15692 Rev.0, August 2001.

A44. "Analysis of Capsule $V$ from Pacific Gas and Electric Company Diablo Canyon Unit 2 Reactor Vessel Radiation Surveillance Program," WCAP-15423 Rev.0, September 2000.

A45. "Reactor Vessel material Surveillance Program for Indian Point Unit No.2 Analysis of Capsule V," SwRI Project No. 17-2108, March 1990.

A46. "Analysis of Capsule $U$ from the Indiana Michigan Power Company D.C. Cook Unit 2 Reactor Vessel Radiation Surveillance Program," WCAP-13515 Rev.1, May 2002.

A47. "Analysis of Capsule V from FPL Energy - Seabrook Unit 1 Reactor Vessel Radiation Surveillance Program," WCAP-16526-NP Rev.0, March 2006.

A48. "Analysis of Capsule Z from the Tennessee Valley Authority, Watts Bar Unit 1 reactor Vessel Radiation Surveillance Program," WCAP-16760-NP Rev.0, November 2007.

A49. "Analysis of Capsule $U$ from the American Electric Power Company D.C. Cook Unit 1 Reactor Vessel Radiation Surveillance Program," WCAP-12483 Rev.1, December 2002. 


\section{늘}

A50. "Analysis of Capsule $Z$ from the Southern Nuclear Operating Company Vogtle Unit 2 Reactor Vessel Radiation Surveillance Program," WCAP-17343-NP Rev.0, March 2011.

A51. "McGuire Unit 1 Heatup and Cooldown Limit Curves for Normal Operation," WCAP-15192, May 1999.

A52. "Analysis of Capsule $V$ and the Capsule $Y$ Dosimeters from the Duke Energy Catawba Unit 2 Reactor Vessel Radiation Surveillance Program," WCAP15243, September 1999.

A53. "McGuire Unit 2 Heatup and Cooldown Limit Curves for Normal Operation Using Code Case N-640," WCAP-15201, June 1999.

A54. "Analysis of Capsule $Y$ from the Tennessee Valley Authority Sequoyah Unit 2 Reactor Vessel Radiation Surveillance Program," WCAP-15320 Rev.0, December 1999.

A55. "Sequoyah Nuclear Plant (SQN) - Units 1 and 2 - Updated Pressure Temperature Limits Reports (PTLRs) and Topical Reports for SQN Technical Specification (TS) Change No.00-14," Docket Nos.50-327 and 50-328, September 3, 2003.

A56. "Analysis of Capsule W from the Vogtle Unit No.1 Reactor Vessel Radiation Surveillance Program," WCAP-17009-NP Rev.1, April 2009.

A57. "Sequoyah Unit 1 Heatup and Cooldown Limit Curves for normal Operation and PTLR Support Documentation," WCAP-15293 Rev.1, April 2001.

A58. "Revision to Technical Specification 5.6.6 Reactor Coolant System Pressure and Temperature Limits Report (PTLR)," ULNRC-04158, Callaway Plant, Docket No.50-483, December 3, 1999.

A59. "Analysis of Capsule W from Commonwealth Edison Company Braidwood Unit 2 Reactor Vessel Radiation Surveillance Program," WCAP-15369 Rev.0, March 2000.

A60. "Catawba Unit 1 Heatup and Cooldown Limit Curves for Normal Operation Using Code Case N-640," WCAP-15203 Rev.1, April 2001.

A61. "Analysis of Capsule $X$ from the Northeast Nuclear Energy Company Millstone Unit 3 Reactor Vessel Radiation Surveillance Program," WCAP-15405 Rev.0, May 2000. 


\section{늘}

A62. "Pressure Temperature Limits Report (PTLR)," Byron Unit 1 and 2, Docket Nos.50-454 and 50-455, October 2004.

A63. "Analysis of Capsule W from Commonwealth Edison Company Braidwood Unit 1 Reactor Vessel Radiation Surveillance Program," WCAP-15316 Rev.1, December 1999.

A64. "Pressure Temperature Limits Report (PTLR)," Braidwood Station Unit 1 and 2, Docket Nos.50-456 and 50-457, June 6, 2001.

A65. "Analysis of Capsule $X$ from the TXU Energy Company Comanche Peak Unit 1 Reactor Vessel Radiation Surveillance Program," WCAP-16610-NP Rev.0, September 2006.

A66. "Analysis of Capsule $X$ from the TXU Energy Comanche Peak Unit 2 Reactor Vessel Radiation Surveillance Program," WCAP-16277-NP Rev.0, September 2004.

A67. "Analysis of Capsule X from the Wolf Creek Nuclear Operating Corporation, Wolf Creek Reactor Vessel Radiation Surveillance Program," WCAP-16028 Rev.0, March 2003.

A68. "Pressure-Temperature Curves for Exelon Quad Cities Unit 2," GE-00000002-9600-03R2a Rev.2, May 2004.

A69. "Pressure-Temperature Curves for Exelon Dresden Unit 2," GE-NE-00000002-9629-01a Rev.0, February 2003.

A70. "Pressure-Temperature Curves for Exelon Dresden Unit 3," GE-NE-00000002-9600-01a Rev.0, February 2003.

A71. "Pressure-Temperature Curves for Exelon Quad Cities Unit 1," GE-NE-00000002-9600-02R2a Rev.2, May 2004.

A72. "RPV Fracture Toughness and Material Surveillance Requirements," Vermont Yankee Nuclear Power Station, BVY 03-29, Docket No.50-271, March 26, 2003.

A73. "BWR Vessel and Internals Project - River Bend 183 Degree Surveillance Capsule Report," BWRVIP-113NP, August 2010.

A74. "Relocation of Pressure and Temperature Limit Curves to the Pressure and Temperature Limits Report," Peach Bottom Atomic Power Station Units 2 and 3, Docket Nos.50-277 and 50-278, April 27, 2012. 


\section{LP}

A75. "License Renewal Application," Limerick Generating Station Units 1 and 2, Facility Operating License Nos. NPF-39 and NPF-85.

A76. "License Amendment Request to Revise Technical Specification 3.4.11 Reactor Coolant System (RCS) Pressure and Temperature (P/T) Limits," GO2-04-107, Columbia Generating Station, Docket No.50-397, June 9, 2004.

A77. "License Renewal Application," Susquehanna Steam Electric Station Units 1 and 2, September 2006.

A78. "Changes to Reactor Pressure Vessel Pressure-Temperature (P-T) Limits and Request for Exemption from the Requirements of 10CFR50 Section 50.60(a)," Susquehanna Units 1 and 2, Docket Nos.50-387 and 50-388, July 2001.

A79. "USAR," Clinton Power Station Unit 1, January 2009.

A80. "Revised P-T Limit Curves and Relocation of Pressure-Temperatures (P-T) Curves to the Pressure and Temperature Limits Report (PTLR)," Pilgrim Nuclear Power Station, Docket No.50-293, January 24, 2010.

A81. "Relocation of Pressure and Temperature Limit Curves to the Pressure and Temperature Limits Report," Nine Mile Point Nuclear Station Unit 2, Docket No.50-410, November 21, 2012.

A82. "Pressure and Temperature Limits Report," NEDO-33785 Rev.0, DTE Energy/Enrico Fermi Power Plant 2, October 2012.

A83. "Pressure-Temperature Curves for Exelon LaSalle Unit 1 and 2," GE-NE0000-0003-5526-02R1a Rev.1, Exelon Lasalle Unit 1 and 2, May 2004.

A84. "Request for Change to Technical Specifications - Pressure/Temperature Limits," LR-N04-0136, Hope Creek Generating Station, Docket No.50-354, March 31, 2004.

A85. "License Renewal Application - Results of Safety Evaluation Report (SER) with Open Items Related to License Renewal of Browns Ferry Nuclear Plant Units 1, 2 and 3," Docket Nos.50-259, -260, -296, September 14, 2005.

A86. "Pressure-Temperature Curves for TVA Browns Ferry Unit 1," NEDO-33112 Rev.0, January 2004.

A87. "Pressure-Temperature Curves for TVA Browns Ferry Unit 2," GE-NE-00000013-3193-01a Rev.0, May 2003.

A88. "Request for License Amendments - Changes to Reactor Coolant System Pressure-Temperature Limits and Request for Exemption from 10CFR50, 


\section{LP}

Appendix G, Requirements," BSEP 01-0034, Brunswick Steam Electric Plant, May 1, 2001.

A89. "License Amendment Request to Revise Technical Specification Pressure/Temperature Limit Curves and Surveillance Requirements," NLS2011015, Cooper Nuclear Station, Docket No.50-298, September 22, 2011.

A90. "Pressure-Temperature Curves for PECO Energy Company Limerick Unit 2," GE-NE-B11-00836-00-02a NP Rev.0, July 2000.

A91. "Plant Fitzpatrick RPV Surveillance Materials Testing and Analysis of $120^{\circ}$ Capsule at 13.4 EFPY," GE-NE-B1100732-01 Rev.1, February 1998.

A92. "Revision of Reactor Pressure Vessel Pressure-Temperature Limits and Request for Exemption from Requirements of 10CFR 50.60 TAC Nos. MB6687 and MB6703," NMPIL 1697, Nine Mile Point Nuclear Station, Docket No.50-220, November 15, 2002.

A93. "License Renewal Application," Grand Gulf Nuclear Station.

A94. "Request to Revise Technical Specifications: Pressure and Temperature Limits," HL-5932, Edwin I. Hatch Nuclear Plant, Docket Nos. 50-321 and 50366, June 1, 2000.

A95. "Revised P-T Curves Based on New Fluence, Rev.3," OC-05Q-313, Oyster Creek Generating Station.

A96. "Revision of Pressure/Temperature Limit Curves for Non-Nuclear Heatup/Cooldown, Core Critical Operation, and Pressure Testing for Reactor Coolant Systems; Including and Exemption Request Pursuant to 10CFR 50.60(b)," PY-CEI/NRR-2627L, Perry Nuclear Power Plant, Docket No.50440, June 4, 2002.

A97. "Pressure and Temperature Limits Report (PTLR) up to 54 Effective Full Power Years (EFPY)," PTLR Rev.0, Monticello Nuclear Generating Plant.

A98. "Pressure-Temperature Curves for Duane Arnold Energy Center," GE-NEA22-00100-08-01a Rev.0, September 2000.

A99. "Regulatory Guide 1.99, Rev.2," U.S. Nuclear Regulatory Commission, May 1988. 


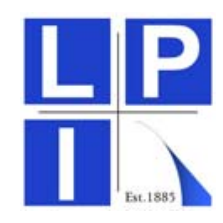

Attachment B

\section{A Review of Design Configuration of the Biological Shield Wall}




\section{B1.0 DESCRIPTION}

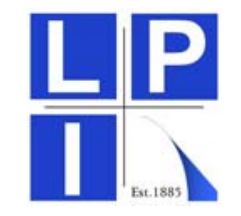

A review of the design of the Biological Shield Wall, relative to support of the reactor pressure vessel was performed. The review utilized information available in [36], together with other design details.

Configuration of the four reactor support types for Westinghouse PWR plants [36], was supplemented by available design information for B\&W, and CE for PWR designs and GE for BWR reactor designs. 


\section{LPP}

Table B1-1: RPV Support Design Configuration

\begin{tabular}{|c|c|c|c|c|c|c|c|c|}
\hline $\begin{array}{c}\text { NSSS } \\
\text { Supplier }\end{array}$ & $\begin{array}{l}\text { Plant } \\
\text { Type }\end{array}$ & Plant & $\begin{array}{c}\text { Plant } \\
\text { Age } \\
\text { (yrs) }\end{array}$ & $\begin{array}{l}\text { No. of } \\
\text { Loops }\end{array}$ & $\begin{array}{l}\text { Number } \\
\text { of RPV } \\
\text { Supports }\end{array}$ & $\begin{array}{c}\text { RPV Support } \\
\text { Type }\end{array}$ & Support Description & $\begin{array}{c}\text { Affect } \\
\text { Concrete } \\
\text { Shield } \\
\text { Wall }\end{array}$ \\
\hline$B \& W$ & PWR & Oconee 1 (B\&W) & 40 & 2 & NA & base skirt & & No \\
\hline$B \& W$ & PWR & Oconee 3 (B\&W) & 39 & 2 & NA & base skirt & & No \\
\hline$B \& W$ & PWR & Oconee 2 (B\&W) & 40 & 2 & NA & base skirt & & No \\
\hline$B \& W$ & PWR & Crystal River 3 (B\&W) & 36 & 2 & & & & \\
\hline$B \& W$ & PWR & Three Mile Island 1 (B\&W) & 39 & 2 & & & & \\
\hline$B \& W$ & PWR & Davis Besse (B\&W) & 36 & 2 & & & & \\
\hline$B \& W$ & PWR & ANO $1(B \& W)$ & 39 & 2 & NA & $\begin{array}{l}\text { base skirt } \\
\text { column }\end{array}$ & & No \\
\hline CE & PWR & Palo Verde 1 (CE) & 28 & 2 & 4 & $\begin{array}{l}\text { supports } \\
\text { column }\end{array}$ & 4 on inlet nozzles & \\
\hline CE & PWR & Palo Verde 2 (CE) & 27 & 2 & 4 & $\begin{array}{l}\text { supports } \\
\text { column }\end{array}$ & 4 on inlet nozzles & \\
\hline CE & PWR & Palo Verde 3 (CE) & 26 & 2 & 4 & supports & 4 on inlet nozzles & \\
\hline CE & PWR & Millstone 2 (CE) & 38 & 2 & & & & \\
\hline CE & PWR & Fort Calhoun (CE) & 40 & 2 & & & & \\
\hline CE & PWR & Palisades (CE) & 42 & 2 & 3 & shoe supports & 2 on inlet, 1 on outlet & Yes \\
\hline CE & PWR & St. Lucie 1 (CE) & 37 & 2 & & & & \\
\hline CE & PWR & St. Lucie 2 (CE) & 30 & 2 & & & & \\
\hline CE & PWR & Calvert Cliff 1 (CE) & 38 & 2 & & & & \\
\hline CE & PWR & Calvert Cliff 2 (CE) & 36 & 2 & & & & \\
\hline CE & PWR & Waterford 3 (CE) & 28 & 2 & 4 & shoe supports & 4 on inlet nozzles & Yes \\
\hline CE & PWR & San Onofre 3 (CE) & 31 & 2 & & & & \\
\hline CE & PWR & San Onofre 2 (CE) & 31 & 2 & & & & \\
\hline CE & PWR & ANO 2 (CE) & 33 & 2 & 3 & $\begin{array}{l}\text { column } \\
\text { supports }\end{array}$ & 2 on inlet, 1 on outlet & No \\
\hline
\end{tabular}

Report No. A13276-R-001

Revision 0 


\begin{tabular}{|c|c|c|c|c|c|c|c|c|}
\hline $\begin{array}{c}\text { NSSS } \\
\text { Supplier }\end{array}$ & $\begin{array}{l}\text { Plant } \\
\text { Type }\end{array}$ & Plant & $\begin{array}{c}\text { Plant } \\
\text { Age } \\
\text { (yrs) }\end{array}$ & $\begin{array}{l}\text { No. of } \\
\text { Loops }\end{array}$ & $\begin{array}{l}\text { Number } \\
\text { of RPV } \\
\text { Supports }\end{array}$ & $\begin{array}{l}\text { RPV Support } \\
\text { Type }\end{array}$ & Support Description & $\begin{array}{c}\text { Affect } \\
\text { Concrete } \\
\text { Shield } \\
\text { Wall }\end{array}$ \\
\hline W & PWR & Point Beach 1 (Westing.) & 43 & 2 & 6 & West. Type 2 & ring support with columns & No \\
\hline W & PWR & Prairie Island 1 (Westing.) & 31 & 2 & 6 & West. Type 1 & shoe and structural weldment & Yes \\
\hline W & PWR & Point Beach 2 (Westing.) & 41 & 2 & 6 & West. Type 2 & ring support with columns & No \\
\hline W & PWR & Prairie Island 2 (Westing.) & 29 & 2 & 6 & West. Type 1 & shoe and structural weldment & Yes \\
\hline W & PWR & Kewaunee (Westing.) & 39 & 2 & 6 & West. Type 1 & shoe and structural weldment & Yes \\
\hline W & PWR & Ginna (Westing.) & 37 & 2 & 6 & West. Type 1 & shoe and structural weldment & Yes \\
\hline W & PWR & H.B. Robinson 2 (Westing.) & 43 & 3 & 3 or 6 & West. Type 1 & shoe and structural weldment & Yes \\
\hline W & PWR & Farley 2 (Westing.) & 32 & 3 & 3 or 6 & West. Type 1 & shoe and structural weldment & Yes \\
\hline W & PWR & Farley 1 (Westing.) & 36 & 3 & 3 or 6 & West. Type 1 & shoe and structural weldment & Yes \\
\hline W & PWR & North Anna 2 (Westing.) & 33 & 3 & 3 or 6 & West. Type 4 & shoe on neutron shield tank & Yes \\
\hline W & PWR & Beaver Valley 2 (Westing.) & 26 & 3 & 3 or 6 & West. Type 4 & shoe on neutron shield tank & Yes \\
\hline W & PWR & Surry 2 (Westing.) & 27 & 3 & 3 or 6 & West. Type 4 & shoe on neutron shield tank & Yes \\
\hline W & PWR & Surry 1 (Westing.) & 37 & 3 & 3 or 6 & West. Type 4 & shoe on neutron shield tank & Yes \\
\hline W & PWR & North Anna 1 (Westing.) & 35 & 3 & 3 or 6 & West. Type 4 & shoe on neutron shield tank & Yes \\
\hline W & PWR & Summer (Westing.) & 31 & 3 & 3 or 6 & West. Type 1 & shoe and structural weldment & Yes \\
\hline W & PWR & Harris (Westing.) & 32 & 3 & 3 or 6 & West. Type 1 & shoe and structural weldment & Yes \\
\hline W & PWR & Beaver Valley 1 (Westing.) & 37 & 3 & 3 or 6 & West. Type 4 & shoe on neutron shield tank & Yes \\
\hline W & PWR & Turkey Point 3 (Westing.) & 41 & 3 & 3 or 6 & West. Type 1 & shoe and structural weldment & Yes \\
\hline W & PWR & Turkey Point 4 (Westing.) & 40 & 3 & 3 or 6 & West. Type 1 & shoe and structural weldment & Yes \\
\hline W & PWR & South Texas (Westing.) & 25 & 4 & 4 & West. Type 1 & shoe and structural weldment & Yes \\
\hline W & PWR & Diablo Canyon 1 (Westing.) & 29 & 4 & 4 & West. Type 3 & shoe supports on ring & Yes \\
\hline W & PWR & Indian Point 3 (Westing.) & 37 & 4 & 4 & West. Type 3 & shoe supports on ring & Yes \\
\hline W & PWR & Salem 1 (Westing.) & 41 & 4 & 4 & West. Type 1 & shoe and structural weldment & Yes \\
\hline W & PWR & Salem 2 (Westing.) & 44 & 4 & 4 & West. Type 1 & shoe and structural weldment & Yes \\
\hline W & PWR & Diablo Canyon 2 (Westing.) & 28 & 4 & 4 & West. Type 3 & shoe supports on ring & Yes \\
\hline
\end{tabular}




\begin{tabular}{|c|c|c|c|c|c|c|c|c|}
\hline $\begin{array}{c}\text { NSSS } \\
\text { Supplier }\end{array}$ & $\begin{array}{l}\text { Plant } \\
\text { Type }\end{array}$ & Plant & $\begin{array}{l}\text { Plant } \\
\text { Age } \\
\text { (yrs) }\end{array}$ & $\begin{array}{l}\text { No. of } \\
\text { Loops }\end{array}$ & $\begin{array}{l}\text { Number } \\
\text { of RPV } \\
\text { Supports }\end{array}$ & $\begin{array}{c}\text { RPV Support } \\
\text { Type }\end{array}$ & Support Description & $\begin{array}{c}\text { Affect } \\
\text { Concrete } \\
\text { Shield } \\
\text { Wall }\end{array}$ \\
\hline W & PWR & Indian Point 2 (Westing.) & 40 & 4 & 4 & West. Type 3 & shoe supports on ring & Yes \\
\hline W & PWR & D.C. Cook 2 (Westing.) & 35 & 4 & 4 & West. Type 1 & shoe and structural weldment & Yes \\
\hline W & PWR & Seabrook (Westing.) & 30 & 4 & 4 & West. Type 1 & shoe and structural weldment & Yes \\
\hline W & PWR & Watts Bar 1 (Westing.) & 17 & 4 & 4 & West. Type 1 & shoe and structural weldment & Yes \\
\hline W & PWR & D.C. Cook 1 (Westing.) & 38 & 4 & 4 & West. Type 1 & shoe and structural weldment & Yes \\
\hline W & PWR & Vogtle 2 (Westing.) & 24 & 4 & 4 & West. Type 1 & shoe and structural weldment & Yes \\
\hline W & PWR & McGuire 1 (Westing.) & 32 & 4 & 4 & West. Type 1 & shoe and structural weldment & Yes \\
\hline W & PWR & Catawba 2 (Westing.) & 27 & 4 & 4 & West. Type 1 & shoe and structural weldment & Yes \\
\hline W & PWR & McGuire 2 (Westing.) & 30 & 4 & 4 & West. Type 1 & shoe and structural weldment & Yes \\
\hline W & PWR & Sequoyah 2 (Westing.) & 33 & 4 & 4 & West. Type 1 & shoe and structural weldment & Yes \\
\hline W & PWR & Vogtle 1 (Westing.) & 26 & 4 & 4 & West. Type 1 & shoe and structural weldment & Yes \\
\hline W & PWR & Sequoyah 1 (Westing.) & 23 & 4 & 4 & West. Type 1 & shoe and structural weldment & Yes \\
\hline W & PWR & Callaway (Westing.) & 29 & 4 & 4 & West. Type 1 & shoe and structural weldment & Yes \\
\hline W & PWR & Braidwood 2 (Westing.) & 25 & 4 & 4 & West. Type 1 & shoe and structural weldment & Yes \\
\hline W & PWR & Catawba 1 (Westing.) & 28 & 4 & 4 & West. Type 1 & shoe and structural weldment & Yes \\
\hline W & PWR & Millstone 3 (Westing.) & 27 & 4 & 4 & West. Type 4 & shoe on neutron shield tank & Yes \\
\hline W & PWR & Byron 1 (Westing.) & 28 & 4 & 4 & West. Type 1 & shoe and structural weldment & Yes \\
\hline W & PWR & Braidwood 1 (Westing.) & 26 & 4 & 4 & West. Type 1 & shoe and structural weldment & Yes \\
\hline W & PWR & Comanche 1 (Westing.) & 23 & 4 & 4 & West. Type 1 & shoe and structural weldment & Yes \\
\hline W & PWR & Comanche 2 (Westing.) & 20 & 4 & 4 & West. Type 1 & shoe and structural weldment & Yes \\
\hline W & PWR & Byron 2 (Westing.) & 26 & 4 & 4 & West. Type 1 & shoe and structural weldment & Yes \\
\hline W & PWR & Wolf Creek (Westing.) & 28 & 4 & 4 & West. Type 1 & shoe and structural weldment & Yes \\
\hline GE & BWR & Quad Cities 2 (GE) & 39 & MK-1 & NA & Pedestal & & No \\
\hline GE & BWR & Dresden 2 (GE) & 43 & MK-1 & NA & Pedestal & & No \\
\hline GE & BWR & Dresden 3 (GE) & 42 & MK-1 & NA & Pedestal & & No \\
\hline
\end{tabular}




\begin{tabular}{|c|c|c|c|c|c|c|c|c|}
\hline $\begin{array}{c}\text { NSSS } \\
\text { Supplier }\end{array}$ & $\begin{array}{l}\text { Plant } \\
\text { Type }\end{array}$ & Plant & $\begin{array}{l}\text { Plant } \\
\text { Age } \\
\text { (yrs) }\end{array}$ & $\begin{array}{l}\text { No. of } \\
\text { Loops }\end{array}$ & $\begin{array}{l}\text { Number } \\
\text { of RPV } \\
\text { Supports }\end{array}$ & $\begin{array}{c}\text { RPV Support } \\
\text { Type }\end{array}$ & Support Description & $\begin{array}{c}\text { Affect } \\
\text { Concrete } \\
\text { Shield } \\
\text { Wall }\end{array}$ \\
\hline GE & BWR & Quad Cities 1 (GE) & 40 & MK-1 & NA & Pedestal & & No \\
\hline GE & BWR & Vermont Yankee 1 (GE) & 41 & MK-1 & NA & Pedestal & & No \\
\hline GE & BWR & River Bend 1 (GE) & 27 & MK-3 & NA & Pedestal & & No \\
\hline GE & BWR & Peach Bottom 3 (GE) & 39 & MK-1 & NA & Pedestal & & No \\
\hline GE & BWR & Limerick 1 (GE) & 28 & MK-2 & NA & Pedestal & & No \\
\hline GE & BWR & Columbia 1 (GE) & 29 & MK-2 & NA & Pedestal & & No \\
\hline GE & BWR & Susquehanna 1 (GE) & 41 & MK-2 & NA & Pedestal & & No \\
\hline GE & BWR & Susquehanna 2 (GE) & 40 & MK-2 & NA & Pedestal & & No \\
\hline GE & BWR & Clinton 1 (GE) & 26 & MK-3 & NA & Pedestal & & No \\
\hline GE & BWR & Pilgrim 1 (GE) & 41 & MK-1 & NA & Pedestal & & No \\
\hline GE & BWR & Nine Mile 2 (GE) & 26 & MK-2 & NA & Pedestal & & No \\
\hline GE & BWR & Peach Bottom 2 (GE) & 39 & MK-1 & NA & Pedestal & & No \\
\hline GE & BWR & Fermi 2 (GE) & 27 & MK-1 & NA & Pedestal & & No \\
\hline GE & BWR & LaSalle 1 (GE) & 31 & MK-2 & NA & Pedestal & & No \\
\hline GE & BWR & LaSalle 2 (GE) & 29 & MK-2 & NA & Pedestal & & No \\
\hline GE & BWR & Hope Creek 1 (GE) & 26 & MK-1 & NA & Pedestal & & No \\
\hline GE & BWR & Browns Ferry 1 (GE) & 40 & MK-1 & NA & Pedestal & & No \\
\hline GE & BWR & Browns Ferry 3 (GE) & 37 & MK-1 & NA & Pedestal & & No \\
\hline GE & BWR & Brunswick 2 (GE) & 38 & MK-1 & NA & Pedestal & & No \\
\hline GE & BWR & Browns Ferry 2 (GE) & 39 & MK-1 & NA & Pedestal & & No \\
\hline GE & BWR & Cooper 1 (GE) & 39 & MK-1 & NA & Pedestal & & No \\
\hline GE & BWR & Brunswick 1 (GE) & 37 & MK-1 & NA & Pedestal & & No \\
\hline GE & BWR & Limerick 2 (GE) & 24 & MK-2 & NA & Pedestal & & No \\
\hline GE & BWR & Fitzpatrick 1 (GE) & 38 & MK-1 & NA & Pedestal & & No \\
\hline GE & BWR & Nine Mile 1 (GE) & 44 & MK-1 & NA & Pedestal & & No \\
\hline
\end{tabular}




\section{LP}

\begin{tabular}{|l|l|l|c|c|c|c|c|}
\hline $\begin{array}{c}\text { NSSS } \\
\text { Supplier }\end{array}$ & $\begin{array}{l}\text { Plant } \\
\text { Type }\end{array}$ & \multicolumn{1}{|c|}{ Plant } & $\begin{array}{c}\text { Plant } \\
\text { Age } \\
\text { (yrs) }\end{array}$ & $\begin{array}{c}\text { No. of } \\
\text { Loops }\end{array}$ & $\begin{array}{c}\text { Number } \\
\text { of RPV } \\
\text { Supports }\end{array}$ & $\begin{array}{c}\text { Affect } \\
\text { RPV Support } \\
\text { Type }\end{array}$ & $\begin{array}{c}\text { Support Description } \\
\text { Shield } \\
\text { Wall }\end{array}$ \\
\hline GE & BWR & Grand Gulf 1 (GE) & 29 & MK-3 & NA & Pedestal \\
GE & BWR & Hatch 1 (GE) & 39 & MK-1 & NA & Pedestal \\
GE & BWR & Hatch 2 (GE) & 35 & MK-1 & NA & Pedestal \\
GE & BWR & Oyster Creek 1 (GE) & 44 & MK-1 & NA & Pedestal \\
GE & BWR & Perry 1 (GE) & 27 & MK-3 & NA & Pedestal \\
GE & BWR & Monticello 1 (GE) & 42 & MK-1 & NA & Pedestal \\
GE & BWR & Duane Arnold 1 (GE) & 39 & MK-1 & NA & Pedestal \\
\hline
\end{tabular}




\section{Lucius Pitkin, Inc. Consulting Engineers}

Advanced Analysis

Fitness-For-Service

Failure \& Materials Evaluation

Nondestructive Engineering

Main office \& Laboratory 304 Hudson Street, $4^{\text {th }}$ floor New York, NY 10013-1015

Tel: 212-233-2737

Fax: 212-406-1417

Boston Area Office

36 Main Street, $3^{\text {rd }}$ floor

Amesbury, MA 01913-2807

Tel: $978-517-3100$

Western Region Office

1165 Jadwin Ave

Richland, WA 99352-3434

Tel: 509-420-7684 